Prepared for the U.S. Department of Energy

under Contract DE-AC05-76RL01830

\title{
Secondary Waste Form Down Selection Data Package - Ceramicrete
}

KJ Cantrell

JH Westsik, Jr.

August 2011

Pacific Northwest

NATIONAL LABORATORY

Proudly Operated by Battelle Since 1965 


\title{
DISCLAIMER
}

This report was prepared as an account of work sponsored by an agency of the United States Government. Neither the United States Government nor any agency thereof, nor Battelle Memorial Institute, nor any of their employees, makes any warranty, express or implied, or assumes any legal liability or responsibility for the accuracy, completeness, or usefulness of any information, apparatus, product, or process disclosed, or represents that its use would not infringe privately owned rights. Reference herein to any specific commercial product, process, or service by trade name, trademark, manufacturer, or otherwise does not necessarily constitute or imply its endorsement, recommendation, or favoring by the United States Government or any agency thereof, or Battelle Memorial Institute. The views and opinions of authors expressed herein do not necessarily state or reflect those of the United States Government or any agency thereof.

\author{
PACIFIC NORTHWEST NATIONAL LABORATORY \\ operated by \\ BATTELLE \\ for the \\ UNITED STATES DEPARTMENT OF ENERGY \\ under Contract DE-AC05-76RL01830
}

Printed in the United States of America

Available to DOE and DOE contractors from the

Office of Scientific and Technical Information,

P.O. Box 62, Oak Ridge, TN 37831-0062;

ph: (865) 576-8401

fax: $(865) 576-5728$

email: reports@adonis.osti.gov

\author{
Available to the public from the National Technical Information Service, \\ U.S. Department of Commerce, 5285 Port Royal Rd., Springfield, VA 22161 \\ ph: (800) 553-6847 \\ fax: $(703) 605-6900$ \\ email: orders@ntis.fedworld.gov \\ online ordering: http://www.ntis.gov/ordering.htm
}




\section{Secondary Waste Form Down Selection Data Package - Ceramicrete}

KJ Cantrell

JH Westsik, Jr.

August 2011

Prepared for

the U.S. Department of Energy

under Contract DE-AC05-76RL01830

Pacific Northwest National Laboratory

Richland, Washington 99352 


\section{Summary}

As part of high-level waste pretreatment and immobilized low activity waste processing, liquid secondary wastes will be generated that will be transferred to the Effluent Treatment Facility on the Hanford Site for further treatment. These liquid secondary wastes will be converted to stable solid waste forms that will be disposed in the Integrated Disposal Facility. Currently, four waste forms are being considered for stabilization and solidification of the liquid secondary wastes. These waste forms are Cast Stone, Ceramicrete, DuraLith, and Fluidized Bed Steam Reformer. The preferred alternative will be down selected from these four waste forms. Pacific Northwest National Laboratory is developing data packages to support the down selection process. The objective of the data packages is to identify, evaluate, and summarize the existing information on the four waste forms being considered for stabilization and solidification of the liquid secondary wastes. The information included will be based on information available in the open literature and from data obtained from testing currently underway. This data package is for the Ceramicrete waste form.

Ceramicrete is a relatively new engineering material developed at Argonne National Laboratory to treat radioactive and hazardous waste streams (e.g., Wagh 2004; Wagh et al. 1999a, 2003; Singh et al. 2000). This cement-like waste form can be used to treat solids, liquids, and sludges by chemical immobilization, microencapsulation, and/or macroencapsulation. The Ceramicrete technology is based on chemical reaction between phosphate anions and metal cations to form a strong, dense, durable, low porosity matrix that immobilizes hazardous and radioactive contaminants as insoluble phosphates and microencapsulates insoluble radioactive components and other constituents that do not form phosphates. Ceramicrete is a type of phosphate-bonded ceramic, which are also known as chemically bonded phosphate ceramics. The Ceramicrete binder is formed through an acid-base reaction between calcined magnesium oxide ( $\mathrm{MgO}$; a base) and potassium hydrogen phosphate $\left(\mathrm{KH}_{2} \mathrm{PO}_{4}\right.$; an acid) in aqueous solution. The reaction product sets at room temperature to form a highly crystalline material. During the reaction, the hazardous and radioactive contaminants also react with $\mathrm{KH}_{2} \mathrm{PO}_{4}$ to form highly insoluble phosphates.

In this data package, physical property and waste acceptance data for Ceramicrete waste forms fabricated with wastes having compositions that were similar to those expected for secondary waste effluents, as well as secondary waste effluent simulants from the Hanford Tank Waste Treatment and Immobilization Plant were reviewed. With the exception of one secondary waste form formulation $(25 \mathrm{FA}+25 \mathrm{~W}+1$ B.A. fabricated with the mixed simulant did not meet the compressive strength requirement), all the Ceramicrete waste forms that were reviewed met or exceeded Integrated Disposal Facility waste acceptance criteria. 



\section{Acknowledgments}

The authors acknowledge technical reviews Ken Czerwinski (University of Nevada), Jim Krumhansl (Sandia National Laboratory), John Wiley (retired) and Shas Mattigod (Pacific Northwest National Laboratory) and word processing assistance by Kathy Neiderhiser and editorial review by Hope

Matthews. Pacific Northwest National Laboratory is operated by Battelle Memorial Institute for the U.S. Department of Energy under Contract DE-AC05-76RL01830. 



\section{Acronyms and Abbreviations}

\begin{tabular}{|c|c|}
\hline ANL & Argonne National Laboratory \\
\hline ANS & American Nuclear Society \\
\hline ANSI & American National Standards Institute \\
\hline ASTM & American Society for Testing and Materials \\
\hline $\mathrm{CBPC}$ & chemically bonded phosphate ceramic \\
\hline CFR & Code of Federal Regulations \\
\hline $\mathrm{CTF}$ & Ceramicrete Treatment Facility \\
\hline DOE & U.S. Department of Energy \\
\hline DTA & differential thermal analysis \\
\hline Ecology & Washington State Department of Ecology \\
\hline ETF & Effluent Treatment Facility \\
\hline FBSR & Fluidized Bed Steam Reformer \\
\hline HLW & high-level waste \\
\hline HSW & Hanford Waste Treatment and Immobilization Plant secondary waste \\
\hline IDF & Integrated Disposal Facility \\
\hline IHLW & immobilized high-level waste \\
\hline ILAW & immobilized low activity waste \\
\hline INTEC & Idaho Nuclear Technology and Engineering Center \\
\hline LAW & low-activity waste \\
\hline LDR & Land Disposal Restriction \\
\hline MKP & magnesium potassium phosphate \\
\hline NIST & National Institute of Standards and Technology \\
\hline ORP & U.S. Department of Energy, Office of River Protection \\
\hline PA & performance assessment \\
\hline PCT & product consistency tests \\
\hline PNNL & Pacific Northwest National Laboratory \\
\hline $\mathrm{PZC}$ & point of zero charge \\
\hline RCRA & Resource Conservation and Recovery Act of 1976 \\
\hline SEM & scanning electron microscopy \\
\hline SBS & submerged-bed scrubbers \\
\hline SBW & sodium-bearing waste \\
\hline SNM & Special Nuclear Material \\
\hline TCLP & Toxicity Characteristic Leaching Procedure \\
\hline TRU & transuranic \\
\hline UTS & Universal Treatment Standard \\
\hline XRD & $\mathrm{x}$-ray diffraction \\
\hline
\end{tabular}


WAC

WESP

WRPS

WTP
Washington Administrative Code

wet-electrostatic precipitators

Washington River Protection Solutions, LLC

Hanford Tank Waste Treatment and Immobilization Plant 


\section{Units of Measure}

${ }^{\circ} \mathrm{C}$

Mgal

$\mathrm{MPa}$

mrem

$\mathrm{mSv}$

psi temperature in degrees Celsius

megagallon ( $10^{6}$ gallons $)$

megapascals

millirem

millisievert

pounds per square inch 



\section{Contents}

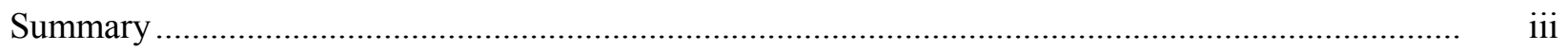

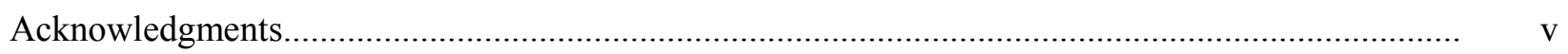

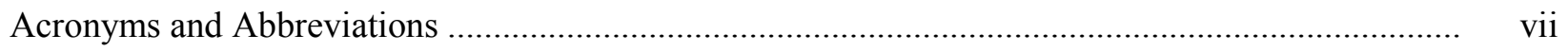

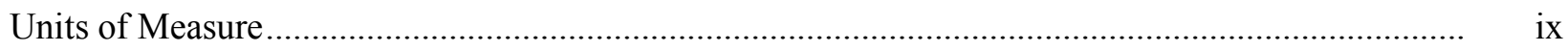

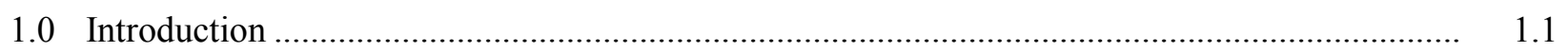

1.1 Origin and Disposition of Liquid Secondary Wastes from Hanford Tank Waste Treatment and Immobilization Plant......................................................................... 1.2

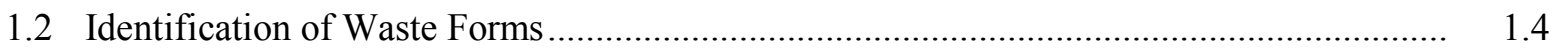

1.3 Secondary Waste Form Down Selection Data Package Content ...................................... 1.5

1.4 Integrated Disposal Facility Waste Acceptance Criteria .................................................. 1.5

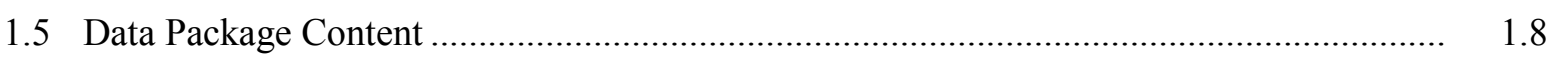

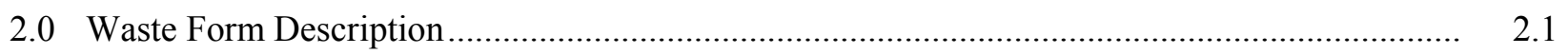

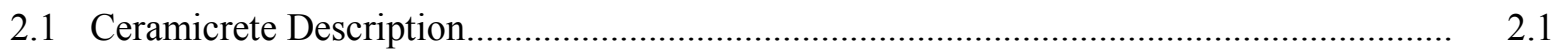

2.1.1 Ceramicrete Formulations for Secondary Wastes ............................................... 2.2

2.1.2 Chemical Compositions of Ceramicrete Waste Forms ........................................ 2.2

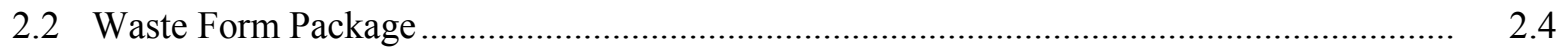

2.3 Range of Wastes and Compositions Tested for Ceramicrete …...................................... 2.5

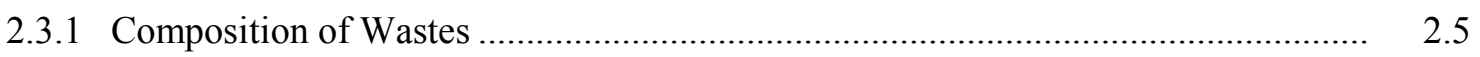

3.0 Ceramicrete Process Description ........................................................................................ 3.1

3.1 Ceramicrete Waste Form Ingredients..................................................................... 3.1

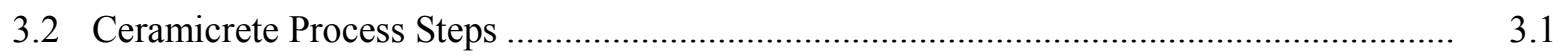

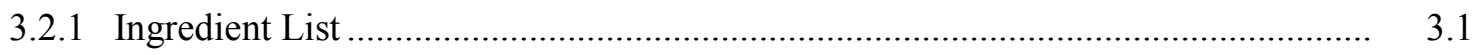

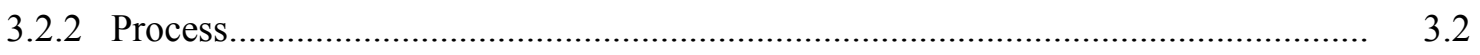

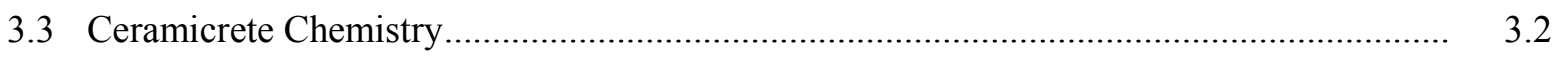

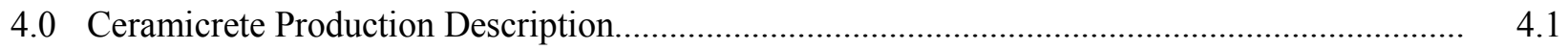

4.1 Ceramicrete Process Description.......................................................................... 4.1

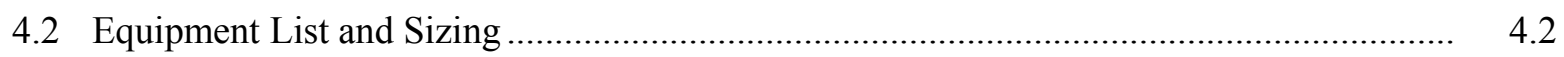

4.3 Existing Facilities and Cost Data .......................................................................... 4.3

5.0 Ceramicrete Physical Properties ..................................................................................... 5.1

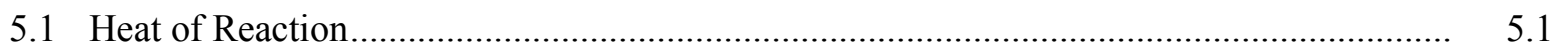

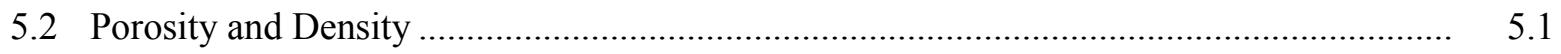

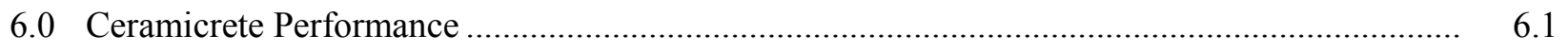

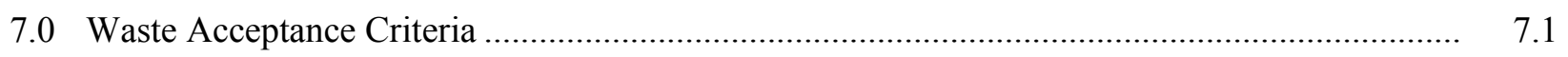

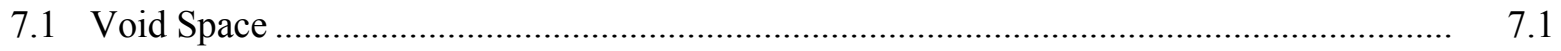

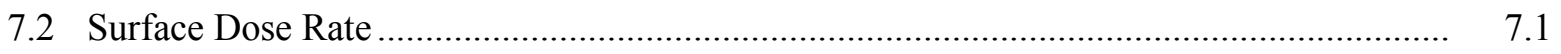

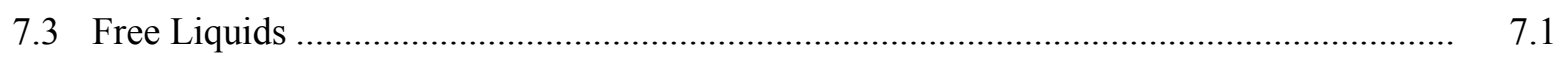

7.4 Dangerous Waste Limitations - Toxicity Characteristic Leaching Procedure................... 7.1 


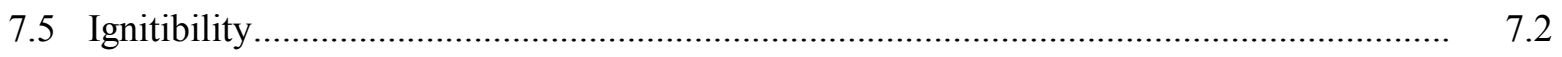

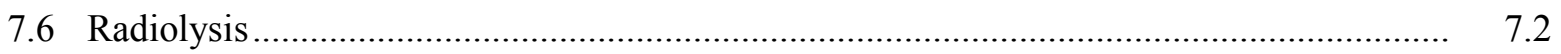

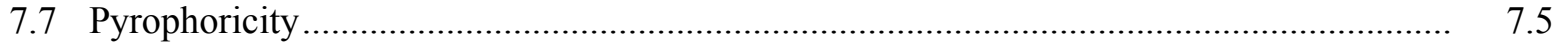

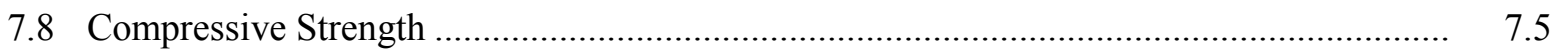

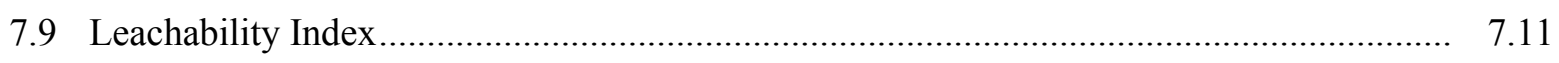

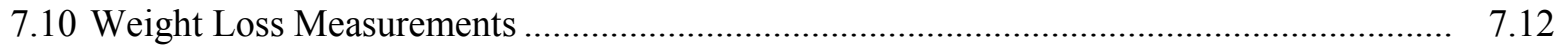

8.0 Summary of Key Ceramicrete Attributes …................................................................

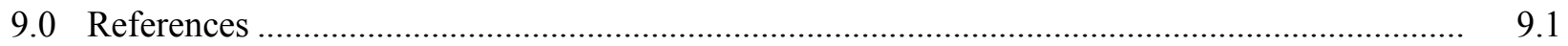

Appendix A - Supplemental Treatment Technology Selection Decision Goals, Criteria, Measures, Technology Issues, and Testing Objectives.......

Appendix B - Initial Draft Waste Form Selection/Waste Acceptance Criteria for Hanford WTP Secondary Waste Form.

B.1 


\section{Figures}

1-1. Schematic of Secondary Waste Sources ................................................................................

3-1. Diagrammatic Representation of Formation of Chemically Bonded Phosphate Ceramics

3-2. Aqueous Solubility Characteristics of Divalent and Trivalent Oxides as a Function of $\mathrm{pH}$.

3-3. Increase in $\mathrm{pH}$ with Time During Neutralization of Calcined and Uncalcined $\mathrm{MgO}$

4-1. Conceptual Flow Diagram for Ceramicrete Process

\section{Tables}

1.1. Supplemental Treatment Technology Selection Decision Goals, Criteria, and Measures.

1.2. Summary of Testing Recommendations for Containerized Grout Technology - Waste Form Performance

2.1. Ceramicrete Waste Form Components in Weight Percent .....

2.2. Ceramicrete Waste Form Compositions in Weight Percent

2.3. Composition of WTP HSW Waste Used for Ceramicrete Formulation .

2.4. Composition of Idaho SBW Waste Used for Ceramicrete Formulation.

2.5. Composition of WTP Secondary Waste Simulants Proposed for Phase 2 Testing.

2.6. Solid Waste Loadings in Ceramicrete Waste Forms.

3.1. Ceramicrete Dry Materials and Potential Sources

3.2. Ingredients for a 51-Gallon Batch of Ceramicrete

4.1. Major Equipment List for Conceptual Ceramicrete Facility.

4.2. Estimated Construction Costs for a Hanford Ceramicrete Facility...

5.1. Porosity and Density Measurements of Ceramicrete Waste Forms.

7.1. TCLP Results for Ceramicrete Waste Forms Fabricated with Wastes Relevant to Secondary Waste Streams.

7.2. TCLP Results on Ceramicrete Waste Forms Fabricated with WTP Secondary Waste Stream Simulants and Blank Samples.....

7.3. Radiolytic Hydrogen Generation in Ceramicrete Containing Various Concentrations of Pu.......

7.4. Compressive Strength Results for Ceramicrete Waste Forms

7.5. Compressive Strength (psi) for Ceramicrete Waste Forms Fabricated with WTP Simulated Secondary Waste.

7.6. Compressive Strength (psi) for Ceramicrete Waste Forms Fabricated with WTP Simulated Secondary Waste.

7.7. Compressive Strength (psi) for Ceramicrete Waste Forms Fabricated with WTP Simulated Secondary Waste. 
7.8. Compressive Strength (psi) for Ceramicrete Waste Forms Fabricated with WTP Simulated Secondary Waste.

7.9. Compressive Strength (psi) for Ceramicrete Waste Forms Fabricated with WTP Simulated Secondary Waste (Baseline) Immersed in Water

7.10. Compressive Strength (psi) for Ceramicrete Waste Forms Fabricated with WTP Simulated Secondary Waste (Cluster 1) Immersed in Water.

7.11. Compressive Strength (psi) for Ceramicrete Waste Forms Fabricated with WTP Simulated Secondary Waste (Cluster 2) Immersed in Water.

7.12. Compressive Strength (psi) for Ceramicrete Waste Forms Fabricated with WTP Simulated Secondary Waste (Mixed) Immersed in Water.

7.13. Leachability Index, Diffusivity (ANSI/ANS-16.1), and Leaching Rate Results (PCT) for Ceramicrete Waste Forms.

7.14. Leaching Index Results from ANS 16.1 Tests Conducted on Ceramicrete Waste Forms Fabricated with WTP Secondary Waste Stream Simulants and Blank Samples

7.15. Weight Loss Results Determined in Water Immersion Tests for Ceramicrete Waste Forms Fabricated with WTP Secondary Waste Stream Simulants and Blank Samples 


\subsection{Introduction}

The Hanford Site, located in southeastern Washington State, has 56 million gal of radioactive and chemically hazardous wastes stored in 177 underground tanks (ORP 2010). The U.S. Department of Energy (DOE), Office of River Protection (ORP), through its contractors, is constructing the Hanford Tank Waste Treatment and Immobilization Plant (WTP) to convert the radioactive and hazardous wastes into stable glass waste forms for disposal. Within the WTP, the pretreatment facility will receive the retrieved waste from the tank farms and separate it into two treated process streams. The pretreated highlevel waste (HLW) mixture will be sent to the HLW Vitrification Facility, and the pretreated low-activity waste (LAW) stream will be sent to the LAW Vitrification Facility. The two WTP vitrification facilities will convert these process streams into glass, which is poured directly into stainless-steel canisters. The immobilized HLW (IHLW) canisters will ultimately be disposed of at an offsite federal repository. The immobilized LAW (ILAW) canisters will be disposed of onsite in the Integrated Disposal Facility (IDF). As part of the pretreatment and ILAW processing, liquid secondary wastes will be generated that will be transferred to the Effluent Treatment Facility (ETF) on the Hanford Site for further treatment. These liquid secondary wastes will be converted to stable solid waste forms that will be disposed in the IDF. Liquid effluents from the ETF will be discharged through the State Approved Land Disposal Site.

The ETF is an existing operating facility on the Hanford Site. It is a Resource Conservation and Recovery Act of 1976 (RCRA) permitted multiwaste treatment and storage unit that can accept Washington State regulated dangerous, low-level, and mixed wastewaters for treatment. The ETF receives, treats, and disposes of liquid effluents from cleanup projects on the Hanford Site. The ETF handles treated effluent under the ETF State Wastewater Discharge Permit, and solidified liquid effluents under the Washington State Department of Ecology (Ecology) Dangerous Waste Permit. The ETF lacks the capacity to treat the liquid process effluents from the WTP after it comes on line for operations.

Milestone M-047-00 of the Hanford Federal Facility Agreement and Consent Order (Ecology et al. 1989) requires that DOE "complete all work necessary to provide facilities for management of secondary liquid waste from the WTP" by "the date that the WTP achieves initial plant operations." Interim milestones are to be negotiated by June 30, 2012. DOE is considering a nonmajor system acquisition project for a Secondary Liquid Waste Treatment Project to add the needed capacity to the ETF (DOE-ORP 2011). Alternatives to be evaluated for providing the needed capacity for handling the WTP liquid secondary wastes include the following:

- Upgrade ETF and construct a Solidification Treatment Unit

- Upgrade ETF with new ion exchange facilities and construct a Solidification Treatment Unit

- Upgrade ETF and recycle evaporator concentrates back to tank farms via truck or pipeline

- Provide additional evaporative capacity and utilize fluidized bed steam reforming.

Washington River Protection Solutions, LLC (WRPS), a prime DOE contractor, is responsible for the ETF upgrades needed to receive secondary liquid wastes from the WTP. In planning for the Secondary Liquid Waste Treatment Project, WRPS anticipates two down selections. The first down selection will evaluate the alternatives and options for providing the necessary capacity for treatment of the secondary liquid wastes from WTP and other Hanford Site liquid waste generators. Then, should the preferred 
alternative include adding a Solidification Treatment Unit, a second down selection would evaluate alternative waste forms for solidification of treated wastes from the ETF.

To support selection of a waste form for the liquid secondary wastes from WTP, WRPS has initiated secondary waste form testing work at Pacific Northwest National Laboratory (PNNL). In 2009, preliminary screening of waste forms was conducted to assess the viability of alternative waste forms for the solidification of the liquid secondary wastes (Pierce et al. 2010a, 2010b). A testing program was initiated to further develop, optimize, and characterize the Cast Stone, Ceramicrete, and DuraLith waste forms to stabilize and solidify the anticipated liquid secondary wastes. Testing was also conducted on a previously prepared Fluidized Bed Steam Reformer (FBSR) waste form to develop a suite of comparable test results such that the performance of all four candidate waste forms could be evaluated.

In anticipation of a down selection process for a waste form for the Solidification Treatment Unit, PNNL is developing data packages to support that down selection. The objective of the data packages is to identify, evaluate, and summarize the existing information on the four waste forms being considered for stabilization and solidification of the liquid secondary wastes. The information included will be based on information available in the open literature and from data obtained from testing currently underway.

\subsection{Origin and Disposition of Liquid Secondary Wastes from Hanford Tank Waste Treatment and Immobilization Plant}

The WTP includes three major treatment facilities including a pretreatment building, a HLW vitrification building, and a LAW vitrification building. Liquid wastes, sludges, and saltcake retrieved from the underground storage tanks will be piped to the pretreatment building. There, the wastes will be separated into a low-volume, HLW stream containing most of the actinides, cesium, and strontium; and a large-volume, LAW stream with most of the sodium and aluminum. From an environmental protection perspective, the largest fractions of the technetium-99 $\left({ }^{99} \mathrm{Tc}\right)$ and iodine-129 $\left({ }^{129} \mathrm{I}\right)$ inventory in the tanks, both long-lived radionuclides, are expected to reside in the LAW stream. The HLW stream will be transferred to the HLW vitrification building where it will be combined with glass forming chemicals and melted in a high-temperature melter and the resulting molten glass will be poured into stainless-steel canisters to cool and sit in storage until it can be shipped to a federal repository. Similarly, the LAW stream will be piped to the LAW vitrification building where it will be melted with glass formers in a high-temperature melter and poured into steel canisters for disposal in IDF.

Secondary liquid wastes will be generated in the pretreatment and vitrification buildings. Figure 1.1 shows a schematic of the sources for the secondary wastes. In the pretreatment building, a front-end evaporator will be used to concentrate liquid wastes received from the underground storage tanks as well as liquid process effluents from the HLW vitrification building. A back-end evaporator will be used to concentrate the LAW from the pretreatment process plus condensates from the LAW melter primary offgas treatment stream. Condensates from the front-end and back-end evaporators will be collected in process condensate collection tanks.

Both the HLW vitrification facility and the LAW vitrification facilities include off-gas treatment systems to treat the gaseous effluents from their respective glass melters. These effluents include water vapor, chemicals volatile at the elevated melter temperatures, and particulates. In each vitrification process, the melter off-gas passes through primary off-gas treatment systems that include submerged-bed 
scrubbers (SBS) and wet-electrostatic precipitators (WESP). Condensates from the HLW SBSs and WESPs are recycled to the pretreatment front-end evaporator. Condensates from the LAW SBSs and WESPs are recycled to the pretreatment back-end evaporator. In addition, the LAW vitrification system includes a secondary off-gas treatment system that includes a final caustic scrubber. A small fraction of the total ${ }^{99} \mathrm{Tc}$ and ${ }^{129}$ I inventory to the LAW vitrification facility is expected to be captured in the caustic scrubber solution. That caustic scrubber solution is recycled back to the condensate collection tanks. Collectively, the pretreatment evaporator condensates and the LAW melter off-gas caustic scrubber solution form the secondary waste stream that is transferred from WTP to ETF for disposition.

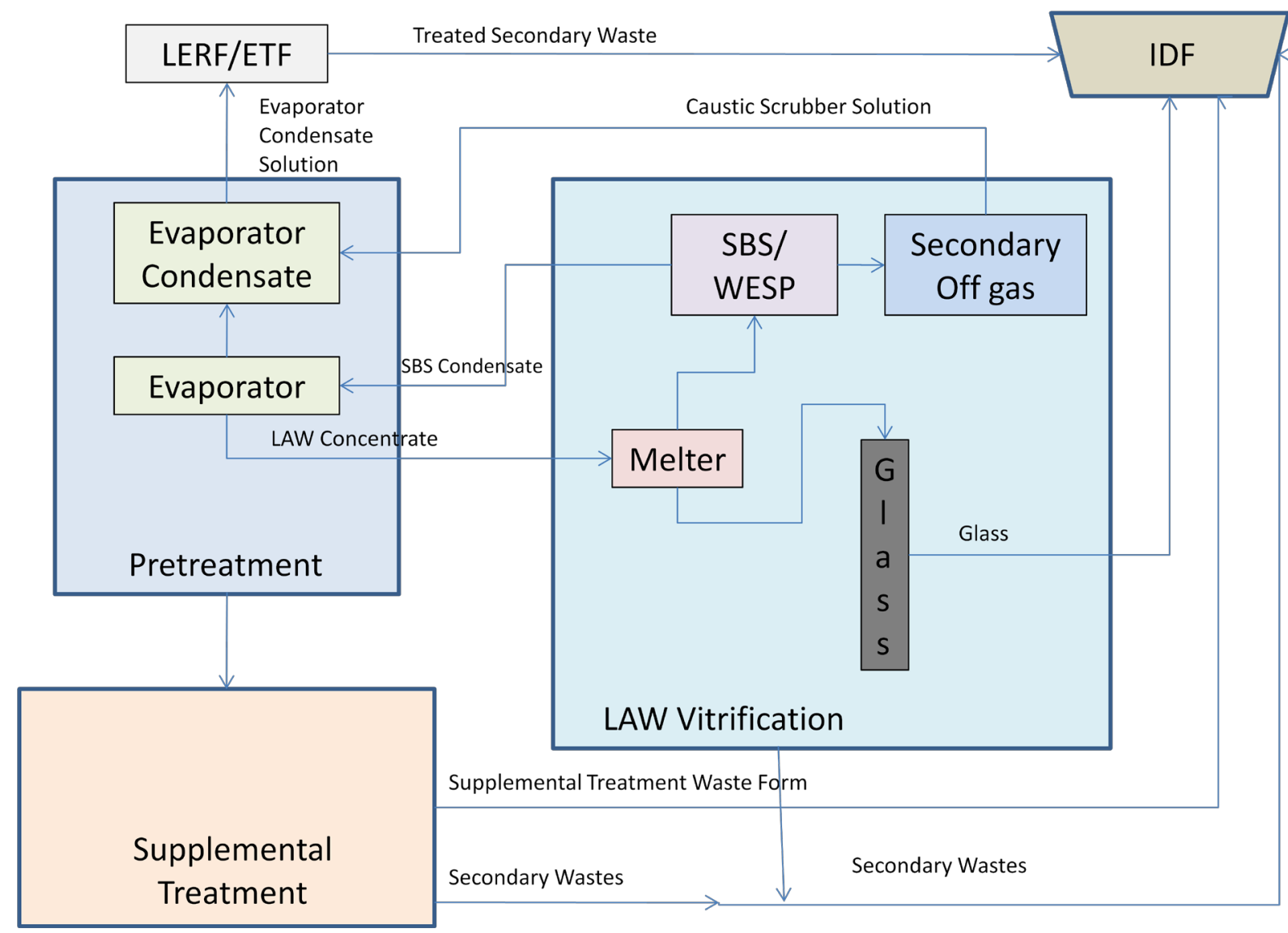

Figure 1.1. Schematic of Secondary Waste Sources

The LAW melter off-gas SBS and WESP condensate are recycled back to the pretreatment facility and ultimately back to the LAW melter. Under some operation scenarios, some or all of the condensate from the LAW melter off-gas SBS and WESP would go directly to a secondary waste stream exiting the WTP. For example, in an "early LAW" scenario, the LAW melter would begin operations using selected tank wastes before the pretreatment facility came on line. In this case, the SBS and WESP condensates would be combined with the caustic scrubber as a single liquid secondary waste stream from the WTP. In another scenario, a fraction of the SBS and WESP condensate would be bled from the recycle stream that is sent back to the pretreatment facility to limit the buildup of constituents in the LAW melter feed that would reduce the waste loading in the LAW glass. In some recent secondary waste form testing, a $10 \%$ fraction of the SBS and WESP condensate was assumed to be bled off and combined with caustic scrubber in the secondary waste stream to ETF. 
Currently defined secondary waste streams originate from the WTP and do not consider alternative supplemental treatment technologies. A second LAW melter facility would operate under the same assumptions as the first LAW melter facility. In the baseline case, approximately $626 \mathrm{Mgal}$ of radioactive dangerous liquid effluent (secondary waste from the WTP, the second LAW facility, 242-A Evaporator, an aluminum removal facility, and supplemental transuranic [TRU] treatment system) is projected to be treated by the ETF over the duration of the treatment mission (DOE-ORP 2010).

\subsection{Identification of Waste Forms}

Numerous waste forms have been evaluated for the stabilization and solidification of radioactive and hazardous wastes. Radioactive high-level wastes from nuclear fuel reprocessing are converted to a glass waste form in stainless-steel canisters for disposal at a federal repository. Liquid low-level wastes and mixed radioactive and hazardous waste are typically stabilized and solidified before disposal in nearsurface facilities. Spence and Shi (2005) provide a review of inorganic and organic binders that have been used for waste stabilization. Several recent studies have evaluated technologies specifically for solidification of WTP liquid secondary wastes. In 2006, PNNL completed an evaluation of three lowtemperature waste forms including an alkali-alumino-silicate hydroceramic cement, DuraLith alkali alumino-silicate geopolymer, and Ceramicrete phosphate bonded ceramic (Russell et al. 2006). Alternatives to vitrification and Portland cement-based grouts were identified through an unrestricted request for proposals. Relatively mature, low-temperature $\left(<150^{\circ} \mathrm{C}\right)$ processes with the feasibility of deployment within 1 to 2 years were favored by the evaluation criteria. That study demonstrated the potential of DuraLith alkali alumino-silicate geopolymer and Ceramicrete phosphate-bonded ceramic as adequate waste forms for the secondary wastes. As part of the Advanced Remediation Technologies program, THOR Treatment Technologies and Savannah River National Laboratory (SRNL) demonstrated the feasibility of a FBSR granular product encapsulated in a geopolymer matrix using an early LAW secondary waste stream composed of LAW off-gas treatment condensates that would normally be recycled within the WTP plant (THOR 2009).

The first activity for the Secondary Waste Form Testing project at PNNL was to conduct a literature survey to identify and evaluate candidate waste forms for solidifying the secondary wastes (Pierce et al. 2010a). In addition to the baseline Cast Stone Portland cement-based waste form, DuraLith, Ceramicrete, and FBSR waste form, several less mature technologies including several aluminosilicates and an iron-oxide mineral called goethite with the capacity to specifically retain technetium were identified. In parallel, WRPS issued a call for expressions of interest for secondary waste immobilization technologies. Responses to that call included a glass waste form produced with the Geomelt Vitrification Technology, a waste form based on the synroc ceramic titanate mineral, and a Nochar waste form prepared from a blend of acrylics and acrylamide copolymers (Pierce et al. 2010a).

Based on the technical literature and previous testing, four waste forms were selected for further testing and evaluation for the stabilization and solidification of WTP liquid secondary wastes. Included are the following:

- Cast Stone Portland-cement based waste form

- Ceramicrete phosphate bonded ceramic 
- DuraLith alkali alumino-silicate geopolymer

- FBSR granular product encapsulated within a geopolymer waste form.

Additional testing was performed in 2010 to further develop and optimize Cast Stone, DuraLith, and Ceramicrete for the projected liquid secondary waste compositions. Testing is also being conducted on a FBSR waste form. At the conclusion of this current development and optimization task, PNNL plans on testing each optimized waste form to demonstrate compliance with the IDF criteria to support the final waste form selection. Part of that testing includes engineering-scale demonstrations of the DuraLith and Ceramicrete waste form processes and characterization of the resulting engineering-scale waste form products.

\subsection{Secondary Waste Form Down Selection Data Package Content}

In defining the content to be provided in the waste form down selection data packages, previous waste form selection processes at the Hanford Site were examined. In 2002, DOE implemented a plan to accelerate cleanup of the Hanford Site. Part of that plan was to conduct supplemental tank waste processing external to the WTP. Three waste form technologies (containerized grout, bulk vitrification, and fluidized-bed steam reforming) were considered (Raymond et al. 2004). A selection criteria workshop and follow-up meetings were conducted with DOE, Ecology, and the U.S. Environmental Protection Agency (EPA), and contractor management and technical staff. Through that process, 6 treatment goals, 10 selection criteria, and 14 measures were identified to aid in supplemental waste form selection (shown in Table 1.1).

In addition, to support the supplemental treatment waste form evaluation, Josephson et al. (2003) identified laboratory and engineering data needed to address the goals, selection criteria, and measures for the down selection. Specific recommendations were provided for the containerized grout and the bulk vitrification options. Table 1.2 lists the technical issues and uncertainties and the testing objectives that should be addressed to resolve the identified issues and uncertainties for the containerize grout technology.

Types of data were identified to address each of the goals, criterion, and measures developed for the supplemental treatment down selection, and the technical issues/uncertainties and testing objectives recommended for the containerized grout. Appendix A includes expanded Tables 1.1 and 1.2 with the data package contents to address each measure and testing objective.

\subsection{Integrated Disposal Facility Waste Acceptance Criteria}

Wastes intended for disposal in IDF must meet requirements of DOE Order 435.1 and permit requirements established by Ecology. The IDF permit does not identify specific waste acceptance criteria for solidified secondary wastes; however, it does require the following:

Six months prior to IDF operations, Permittees shall submit to Ecology for review, approval, and incorporation into the permit, all waste acceptance criteria (WAC) to address at a minimum, the following: physical/chemical criteria, liquids and liquid containing waste, land disposal restriction treatment standards and prohibitions, 
compatibility of waste with liner, gas generation, packaging, handling of packages, minimization of subsidence.

Table 1.1. Supplemental Treatment Technology Selection Decision Goals, Criteria, and Measures ${ }^{(a)}$

\begin{tabular}{|c|c|c|}
\hline Goal & Criterion & Measures \\
\hline Ensure worker and public safety & Achieve inherently safe system & $\begin{array}{l}\text { Independent safety expert } \\
\text { assessment }\end{array}$ \\
\hline \multirow{3}{*}{$\begin{array}{l}\text { Provide environmental protection } \\
\text { comparable to current vitrified waste } \\
\text { disposal plan }\end{array}$} & Waste form performance & $\begin{array}{l}\text { Flux at points of undisturbed soil } \\
\text { and bottom of the waste packages }\end{array}$ \\
\hline & Disposal space required & Acres of land for disposal site \\
\hline & Secondary wastes produced & $\begin{array}{l}\text { Potential to emit constituents: solid } \\
\text { waste volume, liquid waste volume }\end{array}$ \\
\hline \multirow[t]{2}{*}{ Maximize schedule acceleration } & Confidence in meeting 2028 date & $\begin{array}{l}50 \% \text { probability data for achieving } \\
10 \text { GPM throughput }\end{array}$ \\
\hline & Process robustness & $\begin{array}{l}\text { Metric tons of sodium }(\mathrm{Na}) \\
\text { processed by } 2028\end{array}$ \\
\hline \multirow[t]{2}{*}{ Maximize cost effectiveness } & Life cycle cost & Life cycle cost \\
\hline & Peak year cost & Peak year cost \\
\hline Maximize operability & Operability risk & $\begin{array}{l}\text { Independent expert assessment to } \\
\text { include number of unit operations; } \\
\text { equipment count, etc. }\end{array}$ \\
\hline \multirow[t]{3}{*}{$\begin{array}{l}\text { Minimize overall system interface } \\
\text { impacts }\end{array}$} & System interface impacts & $\begin{array}{l}\text { Liquid effluent greater than ETF } \\
\text { capacity }\end{array}$ \\
\hline & & $\begin{array}{l}\text { Dose of waste package (impacting } \\
\text { handling within disposal system }\end{array}$ \\
\hline & & $\begin{array}{l}\text { Volume returned to double-shell } \\
\text { tanks (impacting stored waste } \\
\text { volume) }\end{array}$ \\
\hline
\end{tabular}

(a) Raymond et al. (2004).

IDF waste acceptance criteria have not been established for wastes to be disposed in the facility. There have been several draft WAC proposed - some limited to the ILAW glass waste form and bulk vitrification waste form. Others have included criteria applicable to other waste forms as well (RPP 2005). Appendix B lists initial draft waste acceptance criteria for a secondary waste form based on the February 2005 draft IDF WAC (RPP 2005) and the data package content to address each criterion. Included are criteria with respect to free liquids, compliance with LDRs, compressive strength, and leachability. For the purposes of the secondary waste form down selection, the following requirements apply:

- LDRs: The waste form will meet the land disposal requirements in 40 Code of Federal Regulations (CFR) 268 by meeting the universal treatments standards in 40 CFR 268.48 via the Toxicity Characteristic Leaching Procedure (TCLP) test. 
Table 1.2. Summary of Testing Recommendations for Containerized Grout Technology - Waste Form Performance $^{(\mathrm{a})}$

$$
\text { Technical Issue/Uncertainty }
$$

Data on nitrate/nitrite and $\mathrm{Cr}$ release rates from test samples to meet PA data needs

Retention of Tc, U, and I as a function of waste loading

Identification of constituents that might be poorly retained by grout and may impact permitting

Validity of simulant testing

Effects of mitigating features on environmental performance

Data to support grout facility design

\section{Testing Objective}

Optimize grout formulation to provide highest waste loading with lowest release rate

Performance on nitrate/nitrite likely to be limiting factor on waste loading

Determine waste loading/performance relationship (until a target for release is set, the relationship is more important than determining a waste loading that meets a criterion)

Gather enough Tc, U, and I release data to meet PA data needs

Determine waste loading/performance relationship (until a target for release rate is set, the relationship is more important than determining a waste loading that meets a criterion.)

Determine other key risk drivers and make suitable measurements to support calculations/models. RCRA metals, other radionuclides (e.g., Cs), all listed waste constituents (series of codes for solvents F001-F005), LDR organics and inorganics, and criteria metrics-fish bioassay.

Demonstrate that simulant and actual waste release rates match

Verify that solidification materials locally available at the Hanford Site produce desired results

Determine efficacy of proposed "getters"

Determine efficacy of mitigating features for preventing contaminants from leaving the disposal system

Estimate expected efficacy of proposed feature for longterm Hanford Site application

Collect grout curing and strength data

Collect data on $\mathrm{H}_{2}$ generation in container

Collect data on amount of leachate generated as grout cures(or use existing data with engineering analysis if sufficient to address issue)

(a) Josephson et al. (2003).

LDR $=$ Land disposal restriction.

PA $=$ Performance assessment. 
- Free Liquids: The waste form shall contain no detectable free liquids as defined in SW-846 Method 9095

- Leachability Index: The waste form shall have a sodium leachability index greater than 6.0 when tested in deionized water using the ANSI/ANS-16.1 method (ANS 1986) or EPA Method 1315. The waste shall have a rhenium or technetium leachability index greater than 9.0. These requirements are based on the Nuclear Regulatory Commission's Technical Position on Waste Form (NRC 1991), early waste disposal risk assessments, and performance assessment analyses. The stated values need to be validated and verified based on more recent assessments.

- Compressive Strength: The compressive strength of the waste form shall be at least 3.54E6 Pa (500 psi) when tested in accordance with ASTM C39/C39M. This requirement is based on Technical Position on Waste Form (NRC 1991), which is more restrictive for cement-based waste forms.

\subsection{Data Package Content}

The data package begins with a description of the waste form in Section 2.0. This includes the primary waste form, any encapsulating materials, waste form packaging, and types of wastes tested. Section 3.0 describes the waste form preparation process including starting materials and processing steps. Section 4.0 expands upon the information in Section 3.0 to include flow sheet and equipment descriptions, process control, off-gas treatment and process effluents, and any existing test and production facilities. Physical properties of the waste form are presented in Section 5.0. Section 6.0 focuses on waste form performance, including leach test results and mechanisms of radionuclide and hazardous chemical containment and release. Data that address specific IDF waste acceptance criteria are provided in Section 7.0. Section 8.0 concludes with a summary of the strengths and weaknesses of the waste form. 


\subsection{Waste Form Description}

The Ceramicrete disposal package will include the Ceramicrete waste form itself and a container for protection of the waste form during handling, transportation and storage.

\subsection{Ceramicrete Description}

Ceramicrete is a relatively new engineering material developed at Argonne National Laboratory (ANL) to treat radioactive and hazardous waste streams (e.g., Wagh 2004; Wagh et al. 1999a, 2003; Singh et al. 2000). This cement-like waste form can be used to treat solids, liquids, and sludges by chemical immobilization, microencapsulation, and/or macroencapsulation. The Ceramicrete technology is based on chemical reaction between phosphate anions and metal cations to form a strong, dense, durable, and low porosity matrix that immobilizes hazardous and radioactive contaminants as insoluble phosphates and microencapsulates insoluble radioactive components and radioactive components that do not form phosphates. Ceramicrete is a type of phosphate-bonded ceramic, which are also known as chemically bonded phosphate ceramics (CBPC). The Ceramicrete binder is formed through an acid-base reaction between calcined magnesium oxide (MgO; a base) and potassium hydrogen phosphate $\left(\mathrm{KH}_{2} \mathrm{PO}_{4}\right.$; an acid) in aqueous solution:

$$
\mathrm{MgO}+\mathrm{KH}_{2} \mathrm{PO}_{4}+5 \mathrm{H}_{2} \mathrm{O} \rightarrow \mathrm{MgKPO}_{4} \cdot 6 \mathrm{H}_{2} \mathrm{O}
$$

The resulting magnesium potassium phosphate (MKP) phase is used as a matrix material to form a concrete-like waste form that is very stable, with a solubility product of $2.4 \times 10^{-11}$ under ambient conditions (Taylor et al. 1963). The reaction product sets at room temperature to form a highly crystalline material. During the reaction, the hazardous and radioactive contaminants also react with $\mathrm{KH}_{2} \mathrm{PO}_{4}$ to form highly insoluble phosphates. The bulk ceramic then microencapsulates the reacted contaminants in the dense crystalline MKP matrix. X-ray diffraction (XRD) of the ceramic indicates the presence of only the MKP phase and unreacted MgO (Wagh 2004). Similarly, scanning electron microscopy (SEM) indicates the presence of only MKP crystals. Information regarding the MKP phase is sparse. Both Sivaprasad et al. (1990) and Wagh et al. (1999b) have determined its crystal structure and considered this material to be an analog of struvite $\left(\mathrm{NH}_{4} \mathrm{MgPO}_{4} \cdot 6 \mathrm{H}_{2} \mathrm{O}\right)$, in which $\mathrm{NH}_{4}$ is replaced by $\mathrm{K}$. Differential thermal analysis (DTA) and thermogravimetric analysis indicate that the $6 \mathrm{~mol}$ of water in the crystal are loosely bound and are released upon heating at $120^{\circ} \mathrm{C}$, after which anhydrous MKP is formed.

Ceramicrete meets waste disposal acceptance criteria, including compressive strength and universal treatment standards for RCRA metals (as measured by the TCLP [EPA 1992]) to be acceptable for land disposal. The performance and physical properties of the Ceramicrete waste form can be enhanced through addition of silica in the form of fly ash or wollastonite $\left(\mathrm{CaSiO}_{3}\right)$ (Wagh 2004; Wagh et al. 1999a). Compressive strengths of enhanced Ceramicrete are high, typically ranging from 55 to $83 \mathrm{MPa}$ (8000-12,000 psi) (Wagh 2004). In addition to the high strength of the Ceramicrete composites, the ability to form large castings in nearly any desirable configuration (e.g., 55-gal barrels or 4-ft $\times 4$-ft $\times$ 4-ft cubes) is a major advantage.

Ceramicrete has been tested and used to stabilize a variety of waste categories including hazardous wastes, radioactive wastes, and mixed wastes. Additionally, Ceramicrete has been tested and used to stabilize a wide range of solid and aqueous waste streams, including ash, soils, sludges, and debris (Singh 
et al. 1997, 1998; Wagh 2004; Wagh et al. 1997, 1999b). In some cases, reductants have been used to reduce the leachability of certain components such as $\mathrm{Ag}, \mathrm{Cr}(\mathrm{VI})$, and $\mathrm{Tc}(\mathrm{VII})$ from the waste form (Singh et al. 2006; Wagh 2004; Wagh et al. 2003). Reductants that have been used include $\mathrm{Na}_{2} \mathrm{~S}, \mathrm{~K}_{2} \mathrm{~S}$, and $\mathrm{SnCl}_{2}$. Addition of silver zeolite has been used to enhance iodine precipitation (Russell et al. 2006).

Because the scope of this data package is to support evaluation and selection of waste forms for stabilization and solidification of the liquid secondary waste stream from the WTP, detailed discussions of Ceramicrete performance will focus primarily on liquid waste streams that have similar compositions - in some respects - to the secondary waste stream composition expected from the WTP. The secondary waste stream will be composed of liquid wastes from the caustic scrubber in the LAW vitrification facility and evaporator condensates from the pretreatment plant. The caustic scrubber is downstream of the primary LAW vitrification off-gas treatment system and is expected to capture volatile iodine, RCRA metals, and technetium not removed earlier in the process. The primary contaminants of concern in the secondary waste stream are expected to be ${ }^{99} \mathrm{Tc},{ }^{129} \mathrm{I}, \mathrm{Ag}, \mathrm{Cd}, \mathrm{Cr}, \mathrm{Hg}$, and $\mathrm{Pb}$ (Pierce et al. 2010b). Major components of the secondary waste are expected to consist of sodium (2 M), aluminum (0.2 M), hydroxide (1.2 M), nitrate (0.69 M), and oxalate (0.23 M) (Pierce et al. 2010b).

\subsubsection{Ceramicrete Formulations for Secondary Wastes}

Ingredients for Ceramicrete waste forms include magnesium oxide, mono potassium phosphate, and water. Filler materials such as calcium silicate or wollastonite, fly ash, blast furnace slag are added to reduce costs and may actually improve the performance of the Ceramicrete. To reduce the mobility of some contaminants, getter materials are added. Silver zeolite is typically used to retain iodine. Tin chloride is added to reduce technetium and rhenium, which is frequently used as a surrogate for technetium, from the +7 oxidation state to the less mobile +4 oxidation state. Blast furnace slag also helps with this reduction. Sodium sulfide may be added to form the more insoluble sulfide forms of mercury (HgS) and chromium (CrS) (Russell et al. 2006).

Table 2.1 shows the Ceramicrete formulations used in the first Ceramicrete secondary waste forms and for the Idaho Sodium Bearing Waste (SBW) (Russell et al. 2006). These formulations were not optimized but provided an initial laboratory-scale demonstration of the Ceramicrete to these waste streams.

After further testing with different secondary waste simulant solutions and a range of mixes of filler materials, a more refined Ceramicrete formulation was recommended for further characterization with respect to waste form leachability and for engineering-scale demonstrations with the Ceramicrete and simulated secondary waste streams (Singh et al. 2011). This composition is also shown in Table 2.1.

\subsubsection{Chemical Compositions of Ceramicrete Waste Forms}

Table 2.2 lists the chemical composition of Ceramicrete waste forms prepared with Hanford secondary waste simulants and Idaho SBW simulants. 
X-ray absorption near edge spectroscopy examination of a Ceramicrete specimen prepared with a technetium-99-spiked caustic scrubber simulant (see Table 2.5 below) and cured for 3 days showed that the technetium present was nearly 100 percent reduced to the Tc(IV) oxidation state (Um et al. 2011). ${ }^{1}$

Table 2.1. Ceramicrete Waste Form Components in Weight Percent

\begin{tabular}{|c|c|c|c|}
\hline Ingredient & $\begin{array}{l}\text { Idaho Sodium Bearing } \\
\text { Waste (from Russell et al. } \\
\text { 2006) }\end{array}$ & $\begin{array}{c}\text { Hanford } \\
\text { Secondary Waste (from } \\
\text { Russell et al. 2006) }\end{array}$ & $\begin{array}{c}\text { Hanford Secondary } \\
\text { Waste (from Singh et al. } \\
2011 \text { ) }\end{array}$ \\
\hline $\mathrm{MgO}$ & 9.3 & 12.0 & 9.5 \\
\hline $\mathrm{KH}_{2} \mathrm{PO}_{4}$ & 27.8 & 35.9 & 32.4 \\
\hline $\mathrm{CaSiO}_{3}$ & 11.4 & 14.4 & - \\
\hline Fly Ash (Class C) & - & - & 34.3 \\
\hline Silver Zeolite & 1.06 & 1.2 & 1.1 \\
\hline $\mathrm{SnCl}_{2}$ & 0.42 & 0.47 & 1.3 \\
\hline $\mathrm{Na}_{2} \mathrm{~S}$ & 0.42 & - & - \\
\hline Waste Simulant & 47.4 & 25.8 & 19.6 \\
\hline Water & - & - & 1.8 \\
\hline $\mathrm{NaOH}$ (neutralizer) & 2.2 & - & - \\
\hline $\mathrm{H}_{3} \mathrm{PO}_{4}$ (neutralizer) & - & 10.1 & - \\
\hline
\end{tabular}

Table 2.2. Ceramicrete Waste Form Compositions in Weight Percent

\begin{tabular}{lcc}
\hline \multicolumn{1}{c}{ Constituent } & HSW & SBW \\
\hline $\mathrm{Ag}$ & 0.0018 & $2.74 \mathrm{E}-06$ \\
$\mathrm{Al}$ & 0.009 & 1.19 \\
$\mathrm{~B}$ & $2.62 \mathrm{E}-05$ & 0.0075 \\
$\mathrm{Ca}$ & 5.06 & 4.08 \\
$\mathrm{Cd}$ & $2.89 \mathrm{E}-05$ & 0.0047 \\
$\mathrm{Ce}$ & $1.50 \mathrm{E}-07$ & $4.98 \mathrm{E}-05$ \\
$\mathrm{Cl}^{2-}$ & 0.178 & 0.230 \\
$\mathrm{CO}_{3}{ }^{2-}$ & 4.40 & -- \\
$\mathrm{Cr}_{\mathrm{Cs}}$ & $4.56 \mathrm{E}-05$ & 0.0105 \\
$\mathrm{~F}$ & $1.25 \mathrm{E}-06$ & $1.49 \mathrm{E}-06$ \\
$\mathrm{Fe}$ & -- & 0.0529 \\
$\mathrm{Hg}$ & $4.61 \mathrm{E}-05$ & 0.0641 \\
$\mathrm{I}$ & $6.45 \mathrm{E}-06$ & 0.0188 \\
$\mathrm{~K}$ & $2.70 \mathrm{E}-05$ & $2.18 \mathrm{E}-04$ \\
$\mathrm{Mg}$ & 10.5 & 8.49 \\
\hline & 6.89 & 5.63 \\
\hline
\end{tabular}

\footnotetext{
${ }^{1}$ Um, W, RJ Serne, MM Valenta, KE Parker, C-W Chung, G Wang, JS Yang, KJ Cantrell, MH Engelhard, and JH Westsik, Jr. 2011. Radionuclide Retention Mechanisms in Secondary Waste Form Testing: Phase II. Draft, Pacific Northwest National Laboratory, Richland, Washington.
} 
Table 2.2. (contd)

\begin{tabular}{lcc}
\hline $\mathrm{Mn}$ & -- & 0.0415 \\
\hline $\mathrm{Na}$ & 3.57 & 4.74 \\
$\mathrm{NO}_{3}{ }^{-}$ & 0.114 & 17.1 \\
$\mathrm{~Pb}$ & 0.0017 & 0.0171 \\
$\mathrm{P}$ & 11.6 & 6.37 \\
$\mathrm{Re}$ & $9.14 \mathrm{E}-06$ & $4.05 \mathrm{E}-05$ \\
$\mathrm{~S}$ & -- & 0.282 \\
$\mathrm{Si}$ & 3.55 & 2.77 \\
$\mathrm{Sn}$ & 0.299 & 0.263 \\
$\mathrm{TOC}$ & 1.02 & -- \\
$\mathrm{H}{ }_{2} \mathrm{O}$ & 14.9 & 22.0 \\
Total & 62.14 & 73.38 \\
\hline
\end{tabular}

\subsection{Waste Form Package}

The waste form container/package provides both protection and containment for the waste form during production, transportation, and storage. A waste form container or package has not been selected for the waste form (Cast Stone, DuraLith, Ceramicrete, or FBSR). The waste form container will need to meet requirements for transporting radioactive and hazardous materials as specified in 49 CFR 173. The materials of construction for the package must be compatible with the wastes and with the protective liners included in the IDF design. Generally, the package will be fabricated of the following materials, which are acceptable to the IDF:

- Metal, concrete, masonry

- Fire-retardant-treated or painted wood

- Rigid plastic with 25 maximum flame-spread rating or coating

- Flexible plastic packaging materials with similar spread characteristics.

The container size will be dictated by critically safety considerations. A critically safety evaluation for the IDF qualified the following container sizes:

- Fifty-five gal $\left(208 \mathrm{~L}, 0.21 \mathrm{~m}^{3}\right)$ drums, $57.15 \mathrm{~cm}$ diameter $\times 88.14 \mathrm{~cm}$ high $(22.5 \mathrm{in}$. diameter $\times$ 34.7 in. high)

- Eighty-five gal (322 L, $\left.0.32 \mathrm{~m}^{3}\right)$ drums, $66 \mathrm{~cm}$ diameter $\times 100.3 \mathrm{~cm}$ high $(26$ in. diameter $\times 39.5 \mathrm{in}$. high)

- MB-V boxes, $1.2 \mathrm{~m}$ wide $\times 1.2 \mathrm{~m}$ high $\times 2.4 \mathrm{~m}$ long $(4 \mathrm{ft}$ wide $\times 4 \mathrm{ft}$ high $\times 8 \mathrm{ft}$ long $)$

- Medium boxes with a volume between $3.95 \mathrm{~m}^{3}\left(5.17 \mathrm{yd}^{3}\right)$ and $15 \mathrm{~m}^{3}\left(19.62 \mathrm{yd}^{3}\right)$. The dimensions are not fixed.

- Small boxes with a volume less than $3.95 \mathrm{~m}^{3}\left(5.17 \mathrm{yd}^{3}\right)$. The dimensions are not fixed.

Other container configurations may be acceptable but would require a criticality safety evaluation. 
Container size will also be constrained by waste form processing and curing considerations. Any elevated temperatures of the waste form slurry as it is poured into the container will need to be dissipated, as will any heat generated by the curing processes for the waste form. The container will need to be sized and filled such that the heat dissipates without impacting the quality of the waste form. The Ceramicrete reaction between the $\mathrm{MgO}$ and $\mathrm{KH}_{2} \mathrm{PO}_{4}$ is exothermic with temperatures as high as $82^{\circ} \mathrm{C}$ reported for large scale construction application of Ceramicrete in bridges and storage silos for nuclear materials (Russell et al. 2006).

The container will also be configured for ease of filling to maximize the volume of waste form to meet minimum fill requirements and minimize void spaces. The flow and curing characteristics of the waste form are an important consideration in maximizing the fill volume.

The packages will be configured with the appurtenances necessary for safe handling, lifting, and transporting. Appropriate markings and labels will be included for each package.

\subsection{Range of Wastes and Compositions Tested for Ceramicrete}

The compositions of Hanford secondary wastes that were tested in 2005 and 2010 and that of Idaho sodium-bearing waste (SBW) tested previously in 2005 are described in the following sections.

\subsubsection{Composition of Wastes}

The Ceramicrete formulations have been optimized for a range of liquid wastes, including HSWs and Idaho SBWs. The compositions of HSWs and SBWs that were tested during the years 2005 to 2006 are listed in Tables 2.3 and 2.4. The HSW simulant was mainly an $\sim 2 \mathrm{M}$ sodium carbonate solution with minor concentrations of nitrate, hydroxyl, and total organic carbon (TOC) and trace concentrations of Ag, $\mathrm{Cr}, \mathrm{Cd}, \mathrm{I} \operatorname{Re}(\mathrm{Tc}), \mathrm{Hg}$, and $\mathrm{Pb}$. The Idaho SBW was an acidic $\sim 1.9 \mathrm{M}$ sodium nitrate solution with other minor and trace constituents (Table 2.4).

Table 2.3. Composition of WTP HSW Waste Used for Ceramicrete Formulation

\begin{tabular}{cccc}
\hline Element & $\begin{array}{c}\text { Target } \\
(\text { Molar })\end{array}$ & $\begin{array}{c}\text { Target } \\
(\mathrm{g} / \mathrm{L})\end{array}$ & $\begin{array}{c}\text { Analysis } \\
(\mathrm{g} / \mathrm{L})\end{array}$ \\
\hline $\mathrm{Na}$ & 2 & 46 & 45.17 \\
$\mathrm{Al}$ & 0.011 & 0.299 & 0.318 \\
$\mathrm{Cr}$ & $2.80 \mathrm{E}-04$ & 0.0145 & 0.0149 \\
$\mathrm{Ag}$ & $2.20 \mathrm{E}-04$ & 0.0237 & 0.0235 \\
$\mathrm{Cd}$ & $1.40 \mathrm{E}-05$ & 0.00157 & 0.00157 \\
$\mathrm{Re}(\mathrm{Tc})$ & $6.00 \mathrm{E}-07$ & $1.12 \mathrm{E}-04$ & $1.25 \mathrm{E}-04$ \\
$\mathrm{I}$ & $2.90 \mathrm{E}-06$ & $3.68 \mathrm{E}-04$ & NA \\
$\mathrm{Hg}$ & $2.40 \mathrm{E}-06$ & $4.81 \mathrm{E}-04$ & $4.15 \mathrm{E}-04$ \\
$\mathrm{~Pb}$ & $1.50 \mathrm{E}-04$ & 0.031 & 0.0323 \\
$\mathrm{CO}_{3}{ }^{2-}$ & 0.96 & 57.6 & 60 \\
$\mathrm{NO}_{3}^{-}$ & 0.018 & 1.116 & 1.12 \\
$\mathrm{OH}^{-}$ & 0.094 & 1.598 & 1.6 \\
\hline
\end{tabular}


Table 2.3. (contd)

\begin{tabular}{l}
\hline TOC $0.18 \quad 13.86 \quad 13.86$ \\
\hline All analyses were conducted by Noah Laboratory, \\
except the Re(Tc) analysis, which was conducted \\
by Argonne Laboratory, Chicago, Illinois. \\
NA = Not analyzed. \\
Reference: Russell et al. (2006). \\
\hline
\end{tabular}

In more recent Ceramicrete waste form development and optimization, three simulant compositions were used to represent the variability in the composition of the caustic scrubber secondary waste stream. The caustic scrubber is downstream of the primary LAW vitrification off-gas treatment system and is expected to capture volatile iodine and technetium not removed earlier in the process. Further, as part of the overall secondary off-gas treatment system, the caustic scrubber is downstream of the high-efficiency particulate air (HEPA) filters used for particulate removal, the carbon beds for mercury removal, and the selective catalytic reduction beds for oxidizing volatile organic compounds $\mathrm{SO}_{\mathrm{x}}$ and carbon monoxide and for $\mathrm{NO}_{\mathrm{x}}$ reduction. The caustic scrubber liquid effluents are returned to the pretreatment plant where they are combined with the pretreatment evaporator condensates and sent to the LERF/ETF, becoming the source of the secondary wastes requiring treatment. In addition, this report used another (a fourth) simulant to represent the blended caustic scrubber/submerged bed scrubber (SBS)/wet electrostatic precipitator (WESP) liquid waste stream.

Table 2.4. Composition of Idaho SBW Waste Used for Ceramicrete Formulation

\begin{tabular}{cccccccc}
\hline Element & $\begin{array}{c}\text { Target } \\
(\text { moles/L) }\end{array}$ & $\begin{array}{c}\text { Target } \\
(\mathrm{g} / \mathrm{L})\end{array}$ & $\begin{array}{c}\text { Analysis } \\
(\mathrm{g} / \mathrm{L})\end{array}$ & Element & $\begin{array}{c}\text { Target } \\
(\text { moles} / \mathrm{L})\end{array}$ & $\begin{array}{c}\text { Target } \\
(\mathrm{g} / \mathrm{L})\end{array}$ & $\begin{array}{c}\text { Analysis } \\
(\mathrm{g} / \mathrm{L})\end{array}$ \\
\hline $\mathrm{Na}$ & 1.88 & 43.24 & 43.2 & $\mathrm{Ce}$ & $5.30 \mathrm{E}-06$ & $7.43 \mathrm{E}-04$ & $7.82 \mathrm{E}-04$ \\
$\mathrm{Al}$ & 0.575 & 15.5 & 17.8 & $\mathrm{Hg}$ & 0.002 & 0.401 & 0.4 \\
$\mathrm{Ca}$ & 0.0366 & 1.464 & 1.46 & $\mathrm{~Pb}$ & 0.0013 & 0.269 & 0.27 \\
$\mathrm{~B}$ & 0.0102 & 0.11 & 0.11 & $\mathrm{Re}(\mathrm{Tc})$ & $3.13 \mathrm{E}-06$ & $5.83 \mathrm{E}-04$ & $6.37 \mathrm{E}-04$ \\
$\mathrm{Mg}$ & 0.0108 & 0.26 & 0.26 & $\mathrm{I}$ & $5.66 \mathrm{E}-05$ & $7.18 \mathrm{E}-03$ & $3.43 \mathrm{E}-03$ \\
$\mathrm{~K}$ & 0.175 & 6.825 & 6.8 & $\mathrm{SO}_{4}{ }^{2-}$ & 0.0491 & 4.71 & 5.15 \\
$\mathrm{Cr}$ & 0.0033 & 0.172 & 0.172 & $\mathrm{H}_{2} \mathrm{O}$ & 45.1 & 812.7 & 812 \\
$\mathrm{Mn}$ & 0.0126 & 0.69 & 0.69 & $\mathrm{NO}_{3}{ }^{-}$ & 4.91 & 304.4 & 269 \\
$\mathrm{Fe}$ & 0.0178 & 0.993 & 0.99 & $\mathrm{~F}^{-}$ & 0.0403 & 0.765 & 0.83 \\
$\mathrm{Cd}$ & 0.0007 & 0.0786 & 0.078 & $\mathrm{Cl}^{-}$ & 0.0285 & 1.009 & 1.15 \\
$\mathrm{Cs}$ & $7.99 \mathrm{E}-10$ & $1.10 \mathrm{E}-07$ & $2.34 \mathrm{E}-05$ & $\mathrm{H}$ & 1.87 & 1.87 & $\mathrm{NA}$ \\
\hline $\begin{array}{l}\text { All analyses were conducted by Noah Laboratory, except the Cs, Ce, I, Re}(\mathrm{Tc}) \mathrm{SO}_{4}, \mathrm{NO}_{3}, \mathrm{~F}, \text { and } \\
\mathrm{Cl} \text { analysis, which was conducted by Argonne Laboratory, Chicago, Illinois. }\end{array}$ \\
NA = Not analyzed. \\
$\mathrm{Reference:} \mathrm{Russell} \mathrm{et} \mathrm{al.} \mathrm{(2006).}$ \\
\hline
\end{tabular}

The target compositions shown in Table 2.5 are adapted from an analysis of a $\mathrm{G} 2$ flow sheet model run (MRQ 09-0019 Scenario 5.0.22a). The compositions are based on the spreadsheet "Secondary Waste 
Expected Liquid Waste Composition, rev 1.xlsx" provided to PNNL by WRPS. ${ }^{1}$ This spreadsheet provides estimates of the caustic scrubber composition for 241 monthly times. The projected compositions include 32 components (not counting $\mathrm{Na}$ and ones that only had zero values), but only 11 of them plus sodium represent more than 99.9 percent of the non-aqueous molar content of the waste. These 11 components are $\mathrm{OH}^{-}, \mathrm{NO}_{3}^{-}, \mathrm{Al}, \mathrm{CO}_{3}{ }^{-2}, \mathrm{Cl}^{-}, \mathrm{NO}_{2}{ }^{-}, \mathrm{PO}_{4}^{-3}, \mathrm{SO}_{4}^{-2}, \mathrm{Si}, \mathrm{K}$, and $\mathrm{F}^{-}$. Other components, such as RCRA metals and ${ }^{99} \mathrm{Tc}$, are relevant to waste form performance and were included in the simulants. Before selecting the simulant compositions, the compositions for each of the 241 monthly times was charge balanced for the 11 components using sodium and then normalized to a constant sodium concentration (moles per mole $\mathrm{Na}$ ).

The $\mathrm{S} 1$ simulant composition is the median composition (Table 2.5). It was developed by taking the monthly composition estimates from the G2 model over the 241 dates provided and determining the median value for each species over the data set provided. This yielded the concentrations for $\mathrm{OH}^{-}, \mathrm{NO}_{3}{ }^{-}$, $\mathrm{CO}_{3}^{-2}, \mathrm{Cl}^{-}, \mathrm{F}^{-}, \mathrm{NO}_{2}^{-}, \mathrm{PO}_{4}^{-3}, \mathrm{SO}_{4}^{-2}, \mathrm{Si}, \mathrm{K}, \mathrm{Al}$, and $\mathrm{NH}_{4}^{+}$.

Table 2.5. Composition of WTP Secondary Waste Simulants Proposed for Phase 2 Testing

\begin{tabular}{|c|c|c|c|c|c|c|}
\hline $\begin{array}{c}\text { Element } \\
\text { (mole/liter) }\end{array}$ & $\begin{array}{c}\mathrm{S} 1^{(\mathrm{a})} \\
\text { Caustic } \\
\text { Scrubber } \\
\text { Median }\end{array}$ & $\begin{array}{c}\mathrm{S} 2^{(\mathrm{a})} \\
\text { Statistical - } \\
\text { Cluster 1 } \\
3 / 16 / 2038 \\
\end{array}$ & $\begin{array}{c}\mathrm{S}^{(\mathrm{a})} \\
\text { Statistical - } \\
\text { Cluster 2 } \\
05 / 28 / 2024 \\
\end{array}$ & $\begin{array}{c}\mathrm{S} 4^{(\mathrm{a})} \\
\text { Caustic } \\
\text { Scrubber } \\
/ 10 \% \text { of SBS } \\
\text { Blend }\end{array}$ & $\begin{array}{c}\text { Phase } 1 \\
\text { Simulant }\end{array}$ & $\begin{array}{c}\text { Target } \\
\text { Russell et al. } \\
(2006)\end{array}$ \\
\hline $\mathrm{Na}$ & 1 & 1 & 1 & 1 & 2.0 & 2.0 \\
\hline $\mathrm{Al}(\mathrm{OH})_{3}$ & $9.39 \mathrm{E}-02$ & $1.14 \mathrm{E}-01$ & $9.22 \mathrm{E}-02$ & 4.24E-02 & 0.23 & 0.011 \\
\hline $\mathrm{Si}$ & $1.88 \mathrm{E}-03$ & $2.04 \mathrm{E}-03$ & 7.74E-04 & $1.39 \mathrm{E}-02$ & - & - \\
\hline $\mathrm{K}$ & $5.82 \mathrm{E}-04$ & $6.51 \mathrm{E}-04$ & $2.18 \mathrm{E}-03$ & $2.87 \mathrm{E}-02$ & - & - \\
\hline $\mathrm{NH}_{4}^{+}$(total) & --- & --- & --- & $4.41 \mathrm{E}-01$ & - & - \\
\hline $\mathrm{OH}^{-}$ & $3.98 \mathrm{E}-01$ & $3.98 \mathrm{E}-01$ & $3.98 \mathrm{E}-01$ & $1.02 \mathrm{E}-08$ & 1.2 & 0.094 \\
\hline $\mathrm{NO}_{3}^{-}$ & $3.28 \mathrm{E}-01$ & $1.90 \mathrm{E}-01$ & 3.97E-01 & $1.13 \mathrm{E}+00$ & 0.69 & 0.018 \\
\hline $\mathrm{CO}_{3}^{-2}$ & $2.28 \mathrm{E}-02$ & $4.66 \mathrm{E}-02$ & 3.94E-02 & $1.04 \mathrm{E}-02$ & $1.5 \mathrm{E}-6$ & 0.96 \\
\hline $\mathrm{Cl}^{-}$ & $2.25 \mathrm{E}-02$ & $2.17 \mathrm{E}-02$ & 2.91E-02 & $1.04 \mathrm{E}-02$ & - & - \\
\hline $\mathrm{NO}_{2}^{-}$ & $1.20 \mathrm{E}-02$ & $1.05 \mathrm{E}-02$ & 3.83E-02 & $4.31 \mathrm{E}-02$ & - & - \\
\hline $\mathrm{PO}_{4}^{-3}$ & $6.87 \mathrm{E}-03$ & $4.85 \mathrm{E}-03$ & $6.03 \mathrm{E}-03$ & $5.10 \mathrm{E}-03$ & $1.7 \mathrm{E}-2$ & - \\
\hline $\mathrm{SO}_{4}^{-2}$ & $4.41 \mathrm{E}-03$ & $5.81 \mathrm{E}-03$ & $5.14 \mathrm{E}-03$ & $4.36 \mathrm{E}-02$ & $9.7 \mathrm{E}-3$ & - \\
\hline $\mathrm{F}^{-}$ & $5.57 \mathrm{E}-04$ & $3.75 \mathrm{E}-04$ & 4.42E-04 & $1.02 \mathrm{E}-08$ & - & - \\
\hline $\mathrm{Cr}$ & $2.03 \mathrm{E}-04$ & $2.03 \mathrm{E}-04$ & $2.03 \mathrm{E}-04$ & $1.09 \mathrm{E}-03$ & $8.43 \mathrm{E}-3$ & $\begin{array}{c}2.8 \mathrm{E}-04 \\
(100 \mathrm{x})\end{array}$ \\
\hline $\mathrm{Ag}$ & $6.27 \mathrm{E}-06$ & $6.27 \mathrm{E}-06$ & $6.27 \mathrm{E}-06$ & $2.35 \mathrm{E}-05$ & $2.5 \mathrm{E}-4(100 \mathrm{x})$ & $\begin{array}{c}2.2 \mathrm{E}-04 \\
(100 \mathrm{x})\end{array}$ \\
\hline As & $3.48 \mathrm{E}-05$ & $3.48 \mathrm{E}-05$ & $3.48 \mathrm{E}-05$ & $1.61 \mathrm{E}-05$ & - & - \\
\hline $\mathrm{Cd}$ & $1.57 \mathrm{E}-06$ & $1.57 \mathrm{E}-06$ & $1.57 \mathrm{E}-06$ & $2.16 \mathrm{E}-05$ & $5.0 \mathrm{E}-5(100 \mathrm{x})$ & $\begin{array}{c}1.4 \mathrm{E}-05 \\
(100 \mathrm{x})\end{array}$ \\
\hline $\mathrm{Hg}$ & $1.13 \mathrm{E}-05$ & $1.13 \mathrm{E}-05$ & $1.13 \mathrm{E}-05$ & $5.30 \mathrm{E}-06$ & $3.3 \mathrm{E}-5(1 \mathrm{x})$ & $2.4 \mathrm{E}-06$ \\
\hline
\end{tabular}

\footnotetext{
${ }^{1}$ Josephson GB, GF Piepel, and JH Westsik, Jr. 2010. Selection of Secondary Waste Test Compositions. Pacific
} Northwest National Laboratory, Richland, Washington. 
Table 2.5. (contd)

\begin{tabular}{ccccccc}
\hline $\mathrm{Pb}$ & $8.99 \mathrm{E}-06$ & $8.99 \mathrm{E}-06$ & $8.99 \mathrm{E}-06$ & $8.28 \mathrm{E}-06$ & $7.9 \mathrm{E}-4(100 \mathrm{x})$ & $\begin{array}{c}1.5 \mathrm{E}-04 \\
(100 \mathrm{x})\end{array}$ \\
$\mathrm{Tc}$ & $1.81 \mathrm{E}-05$ & $1.81 \mathrm{E}-05$ & $1.81 \mathrm{E}-05$ & $5.59 \mathrm{E}-04$ & $7.7 \mathrm{E}-06$ & - \\
${ }^{99} \mathrm{Tc}(\mathrm{Ci} / \mathrm{Liter})$ & $3.05 \mathrm{E}-05$ & $3.05 \mathrm{E}-05$ & $3.05 \mathrm{E}-05$ & $9.41 \mathrm{E}-04$ & $1.3 \mathrm{E}-5 \mathrm{Ci} / \mathrm{L}$ & \\
\hline $\mathrm{Re}$ & $1.81 \mathrm{E}-05$ & $1.81 \mathrm{E}-05$ & $1.81 \mathrm{E}-05$ & $5.59 \mathrm{E}-04$ & - & $6.00 \mathrm{E}-07(\mathrm{Re})$ \\
\hline $\mathrm{I}^{-}$ & $4.62 \mathrm{E}-06$ & $4.62 \mathrm{E}-06$ & $4.62 \mathrm{E}-06$ & $6.29 \mathrm{E}-05$ & $2.9 \mathrm{E}-6$ & $2.90 \mathrm{E}-06$ \\
\hline${ }^{129} \mathrm{I}(\mathrm{Ci} /$ Liter $)$ & $9.53 \mathrm{E}-08$ & $9.53 \mathrm{E}-08$ & $9.53 \mathrm{E}-08$ & $1.30 \mathrm{E}-06$ & & \\
\hline $\begin{array}{c}\text { TOC }(\text { as } \\
\text { oxalate })\end{array}$ & $9.39 \mathrm{E}-02$ & $1.14 \mathrm{E}-01$ & $9.22 \mathrm{E}-02$ & $4.24 \mathrm{E}-02$ & 0.23 & 0.18 \\
\hline
\end{tabular}

(a) Simulant compositions shown at $1 \mathrm{M} \mathrm{Na}$. Actual target compositions were in the range of $2 \mathrm{M}$ to $10 \mathrm{M} \mathrm{Na}$.

The RCRA metals, technetium, and iodine concentrations chosen were based on their maximum concentrations (moles per mole $\mathrm{Na}$ ) over the 241 dates. In a few cases, it was still necessary to increase the concentrations of selected species to facilitate reasonable analytical detection limits in the testing.

The two "cluster" compositions are based on a statistical analysis of the same G2 model set after charge balancing and were normalized to a constant sodium concentration. In this case, seven dates and corresponding data points were removed as apparent outliers, and the analysis was conducted on the remaining 234 compositions. A cluster analysis of the data showed that the compositions appear to fall into one of two clusters. Two waste compositions were selected from the 234 "realistic" G2 model compositions, one from each cluster. The two representative clusters were selected to maximize the range in concentrations of nitrate plus chloride.

- Simulant S2 is from Cluster 1 and represents a low nitrate plus chloride concentration for that cluster. This is the 3/16/2038 projected composition in the G2 CS data set.

- Simulant S3 is from Cluster 2 and represents a high nitrate plus chloride concentration for that cluster. This is the 5/28/2024 projected composition in the G2 CS data set.

Because of the need to increase the analytical sensitivity for some of the RCRA metals (namely Ag, $\mathrm{As}, \mathrm{Cd}$, and $\mathrm{Pb}$ ), the concentrations of these COCs were spiked at 10 to 100 times their maximum expected concentration. The concentration of $\mathrm{Cr}$ and $\mathrm{Hg}$ were not increased because the simulant concentration for these is sufficient to achieve the analytical sensitivity required to obtain quantitative information from these leach experiments. The same maximum RCRA metal concentrations were used for the three caustic scrubber simulants (S1, S2, and S3). One batch of simulant was prepared and used to make samples of the Cast Stone waste. The three caustic scrubber waste simulants were prepared by mixing $18 \mathrm{M} \Omega$-cm DIW with reagent-grade chemicals.

The fourth simulant (S4) represents the caustic scrubber blended with a bleed stream from the SBS condensate tank, which will receive liquids from the low-activity waste melter SBS and WESP. For this simulant, it was assumed that $10 \%$ of the SBS recycle stream is purged to prevent a buildup of species such as chlorides or sulfates. As mentioned, Table 2.1 shows the four simulants used for the Cast Stone testing. The table also shows the simulant used in the Phase 1 testing (Pierce et al. 2010b) as well as an earlier secondary waste simulant used in an earlier low-temperature immobilization study (Russell et al. 
2006). Components that cannot be detected within the detection limits will be reported as "below the limit." The technetium concentrations used in each simulant were kept above $10^{-5}$ mole/liter regardless of the calculated target concentrations to facilitate detecting technetium in the leachates. All four simulants were analyzed using wet chemical analysis to verify how close they were to the target compositions.

\subsubsection{Waste Loading and Sodium Molarity}

The waste loadings achieved on a solid waste basis during the low temperature waste immobilization testing (Russel et al. 2006) and during secondary waste form testing of ceramicrete (Singh et al. 2011) are listed in Table 2.6. The HSW and SBW simulants were partially neutralized to a pH of 5 with $\mathrm{H}_{3} \mathrm{PO}_{4}$ and $\mathrm{NaOH}$, respectively. The highest waste loading used in Singh et al. (2011) were significantly lower than those used in Russel et al. (2006) particlularly for the HSW S1 waste.

Table 2.6. Solid Waste Loadings in Ceramicrete Waste Forms

\begin{tabular}{lcccccc}
\hline & $\mathrm{HSW}^{(\mathrm{a})}$ & $\mathrm{SBW}^{(\mathrm{a})}$ & $\mathrm{HSW} \mathrm{S1}^{(\mathrm{b})}$ & $\mathrm{HSW} \mathrm{S1}^{(\mathrm{b})}$ & $\mathrm{HSW} \mathrm{S}^{(\mathrm{b})}$ & $\mathrm{HSW} \mathrm{S}^{(\text {(b) }}$ \\
\hline Waste form properties & & & $45 \mathrm{FA}+20 \mathrm{~W}$ & $45 \mathrm{CaSi}+20 \mathrm{~W}$ & $45 \mathrm{FA}+20 \mathrm{~W}$ & $45 \mathrm{CaSi}+20 \mathrm{~W}$ \\
Waste Loading (wt. \%) & $2.87 \%$ & $14.2 \%$ & $1.31 \%$ & $1.35 \%$ & $2.31 \%$ & $2.23 \%$ \\
Na Conc. (M) & 2 & 1.9 & 1 & 1 & 1 & 1 \\
(a) Russel et al. (2006); (b) Singh et al. (2011) & \multicolumn{5}{c}{} \\
\hline
\end{tabular}




\subsection{Ceramicrete Process Description}

The Ceramicrete preparation process is relatively simple. Getter materials such a tin chloride and silver zeolite are added to the liquid waste solution. Then the magnesium oxide and mono potassium phosphate and any fillers are added. The slurry is mixed and is poured into the container to cure. This section includes a description of the ingredients, process steps and times, temperatures, and curing. After this a description of the Ceramicrete process chemistry is provided.

\subsection{Ceramicrete Waste Form Ingredients}

The primary ingredients of Ceramicrete are magnesium oxide, potassium mono phosphate, and water. The $\mathrm{MgO}$ and $\mathrm{KH}_{2} \mathrm{PO}_{4}$ are added in the percentages of 23 weight percent $\mathrm{MgO}$ and 77 weight percent $\mathrm{KH}_{2} \mathrm{PO}_{4}$. Table 3.1 lists the main ingredients and suggested sources.

Table 3.1. Ceramicrete Dry Materials and Potential Sources

\begin{tabular}{ll}
\hline \multicolumn{1}{c}{ Material } & \multicolumn{1}{c}{ Suggested Sources } \\
\hline $\begin{array}{l}\text { MgO (magnesium oxide) } \\
\text { MgO P98 }\end{array}$ & Martin Marietta Magnesia Specialties, MD \\
$\begin{array}{l}\text { MKP (mono potassium phosphate) } \\
\text { MKP-771 }\end{array}$ & $\begin{array}{l}\text { Bindan Corp., Oakbrook, IL } \\
\text { ICL Performance Products, Saint Louis, MO }\end{array}$ \\
Powder Filler & La Farge, Chicago, IL \\
Class C Fly Ash & NYCO, Willsboro, NY \\
Calcium silicate (Wollastonite) & La Farge, Chicago, IL \\
Blast furnace slag & \\
Additives & Fisher Scientific \\
Boric acid, Technical grade, $\mathrm{H}_{3} \mathrm{BO}_{3}$ & Sigma Aldrich \\
Tin chloride, SnCl ${ }_{2}, 98 \%$ Reagent grade & Molecular Products, Golden, CO \\
Ag-loaded zeolite (Ionex Type $\mathrm{Ag}_{400}$ ) & Chem Service \\
Potassium sulfide (I-5130) & Local source \\
\hline Water &
\end{tabular}

\subsection{Ceramicrete Process Steps}

The following steps were followed in the preparation of a 55-gallon drum of Ceramicrete using a simulated secondary waste solution.

\subsubsection{Ingredient List}

Table 3.2 lists the batch recipe used for a 51-gallon batch of Ceramicrete. Boric acid was added as a set retarder. 
Table 3.2. Ingredients for a 51-Gallon Batch of Ceramicrete

\begin{tabular}{lccc}
\hline \multicolumn{1}{c}{ Component } & Chemical Formula & Weight \% & Calculated Weights, $\mathrm{Kg}$ \\
\hline $1 \mathrm{M} \mathrm{Na}^{+}$Simulant & -- & 19.60 & 75.68 \\
Dry Components & & 78.84 & 304.40 \\
Magnesium Oxide & $\mathrm{MgO}$ & 9.53 & 36.80 \\
Mono Potassium Phosphate & $\mathrm{KH}_{2} \mathrm{PO}_{4}$ & 32.41 & 125.14 \\
Class C Fly Ash & -- & 34.31 & 132.47 \\
Stannous Chloride & $\mathrm{SnCl}_{2} 2 \mathrm{H}_{2} 0$ & 1.50 & 5.79 \\
Ground Zeolite - 5A & -- & 1.09 & 4.21 \\
Supplemental Water & $\mathrm{H}_{2} \mathrm{O}$ & 1.56 & 6.02 \\
Totals before boric acid & & 100 & 386.10 \\
Boric acid & & 0.5 & \\
\hline
\end{tabular}

\subsubsection{Process}

1. Weigh the prescribed $\mathrm{MgO}, \mathrm{KH}_{2} \mathrm{PO}_{4}$, and fly ash solids into a mixer and thoroughly mix. Empty the solids from the mixer and save for re-addition, or mix the prescribed solids in another mixer.

2. To the empty mixer, add prescribed weight of $1 \mathrm{M}$ Na waste simulant and continue mixing.

3. Add prescribed weight of $\mathrm{SnCl}_{2}$ and mix for an additional $4 \mathrm{~min}$.

4. Add prescribed weight of zeolite $5 \mathrm{~A}$ and mix for an additional $3 \mathrm{~min}$.

5. Add prescribed weight of supplemental $\mathrm{H}_{2} \mathrm{O}$.

6. Add prescribed weights of previously mixed solids and continue to mix.

7. Mix 15-20 min. and pour slurry into waste container.

\subsection{Ceramicrete Chemistry}

Mg-phosphates are the most developed and studied of the CBPCs and have found several commercial applications including stabilization and solidification of low-level radioactive and hazardous waste (Wagh 2004). A general dissolution model of the kinetics of formation of CBPCs was developed by Wagh and Jeong (2003). A description of this model from Wagh and Jeong (2003) is summarized below.

CBPCs are formed by slowly stirring oxides of metals into an acid phosphate solution such as $\mathrm{H}_{3} \mathrm{PO}_{4}$, $\left(\mathrm{NH}_{4}\right)_{2} \mathrm{HPO}_{4},\left(\mathrm{NH}_{4}\right) \mathrm{H}_{2} \mathrm{PO}_{4}, \mathrm{Al}\left(\mathrm{H}_{2} \mathrm{PO}_{4}\right)_{3}$, or $\mathrm{KH}_{2} \mathrm{PO}_{4}$. Dissolution and dissociation of the acid leads to the formation of ions of phosphates and protons in solution, making the solution acidic. When oxides of metals are stirred into such an ion-rich solution, they go through a number of transformations. The kinetics of these transformations are very similar to the conventional sol-gel process of fabricating ceramics of nonsilicates (Brinker and Scherer 1989), with the major difference being the acid-base reaction used in forming CBPCs carries the mixture all the way to formation of ceramics. In the sol-gel process, the sols are ultimately sintered to form superior ceramics. The step-by-step reactions leading to formation of CBPCs is illustrated in Figure 3.1. When metal oxides are stirred into an acid solution, they 
a. Dissolution of oxide

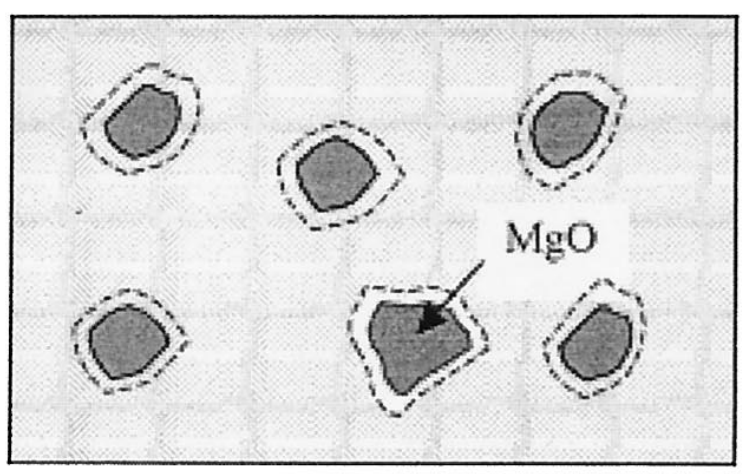

$$
\mathrm{MgO}+\mathrm{H}_{2} \mathrm{O} \rightarrow \mathrm{Mg}^{2+}(\mathrm{aq})+2 \mathrm{OH}^{-}
$$

c. Acid-base reaction and condensation

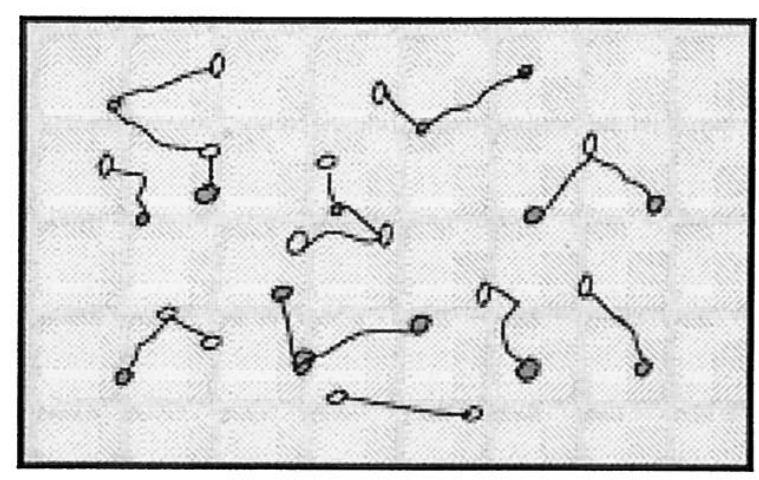

$$
\underset{\rightarrow \mathrm{Mg}(\mathrm{OH})^{2+}(\mathrm{aq})}{\rightarrow \mathrm{MgHPO}_{4} \cdot 3 \mathrm{HPO}_{2} \mathrm{O}}+2 \mathrm{H}_{2} \mathrm{O}
$$

e. Saturation and crystallization b. Formation of aquosols

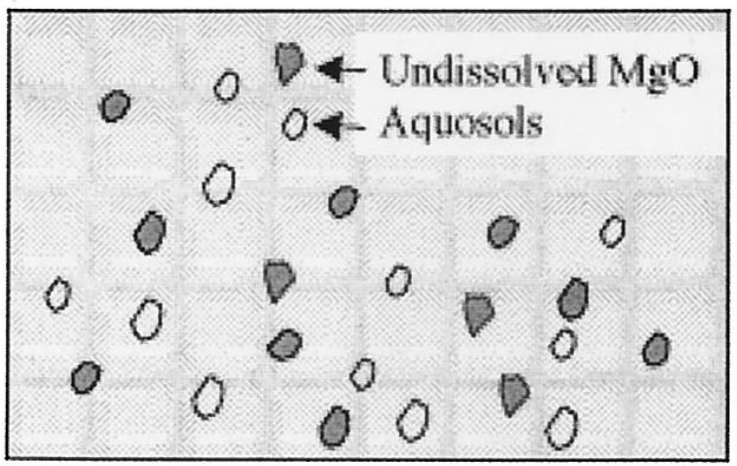

$M g^{2+}(a q)+: O<_{H}^{H} \rightarrow\left[M g \leftarrow O_{\rightarrow H}^{\rightarrow H}\right]^{2+}(a q)$

d. Percolation and gel formation

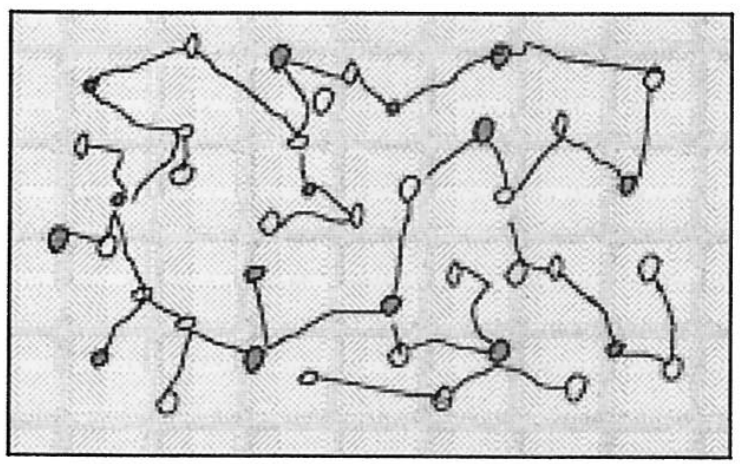

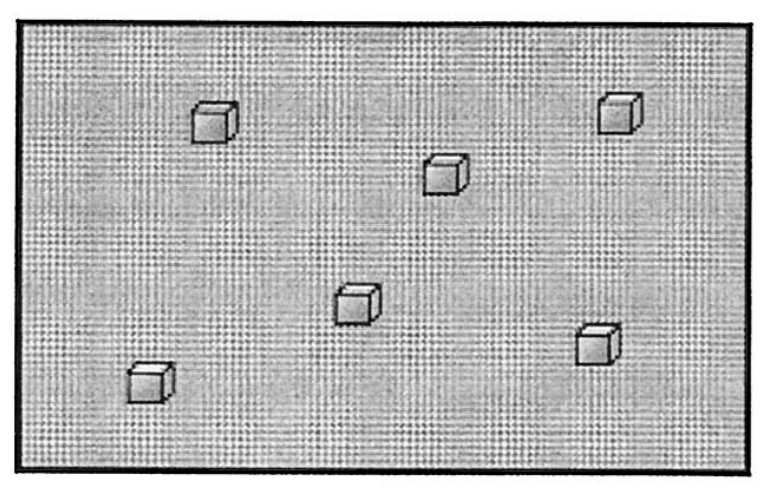

Figure 3.1. Diagrammatic Representation of Formation of Chemically Bonded Phosphate Ceramics (from Wagh and Jeong 2003) 
dissolve slowly, releasing metal cations and hydroxide (Figure 3.1a, dissolution step). The cations react with water molecules and form positively charged "aquosols" through hydrolysis (Figure 3.1b, hydration step). The dissolution and hydrolysis are the rate-controlling steps in forming CBPCs. As illustrated in Figure $3.1 \mathrm{c}$, the sols subsequently react with aqueous phosphate anions to form hydrophosphate salts, while protons react with hydroxide to form water. The newly formed hydrophosphate salts form a network of molecules in solution that leads to formation of a gel (Figure 3.1d). As the reaction proceeds, this process introduces more and more reaction products into the gel, and it thickens. When sufficiently thickened, the gel crystallizes around the unreacted core of each particle of the metal oxide into a wellconnected crystal lattice that grows into a monolithic ceramic (Figure 3.1e).

The dissolution step determines which oxides will form a ceramic and which will not, while the hydration step determines the $\mathrm{pH}$ range in which the ceramics will form. The formation of a wellcrystallized ceramic or a poorly crystallized precipitate will depend on how slowly or rapidly the dissolution of the oxides occurs in the acid solution. The overall acid-base reaction is exothermic, providing heat to the reaction slurry. If this heat raises the temperature of the slurry beyond its boiling point, the slurry will boil over and disrupt the formation of the ceramic. Therefore, the reaction rate of the dissolved species should be slow so the heating of the slurry is not excessive. Thus, the basic two requirements for forming a well-crystallized CBPC are the following: 1) the solubility of the oxides in the solution should be sufficiently high for the formation of a saturated gel but also sufficiently low to allow slow crystallization of the gel; 2) the rate of exothermic heat production and hence the dissolution rate of oxides should be sufficiently slow to allow the phosphate gel to crystallize slowly into a wellordered crystal lattice without interruption, and grow into a monolithic ceramic. These two requirements put upper and lower limits on the solubility of the oxides that can be used to form CBPCs. If the solubility of the oxides is too high, a precipitate is formed, whereas if it is too low, the oxides will not react. These requirements may be quantitatively formulated through consideration of the thermodynamic properties of the oxides in the phosphate solution.

Consider first the dissociation of $\mathrm{H}_{3} \mathrm{PO}_{4}$ itself. The solubility of $\mathrm{H}_{3} \mathrm{PO}_{4}$ is high and its dissociation reaction in solution is given by Equation (3.1).

$$
\mathrm{H}_{3} \mathrm{PO}_{4}=\mathrm{mH}^{+}+\mathrm{H}_{3-\mathrm{m}} \mathrm{PO}_{4}{ }^{\mathrm{m}-}(\mathrm{m}=0-3)
$$

The superscript represents the ionic charge. For $\mathrm{pH}<2.1$, there is little dissociation of the acid and $\mathrm{H}_{3} \mathrm{PO}_{4}$ is the dominant phosphate species in solution $(\mathrm{m}=0)$. Between $\mathrm{pH} 2.1$ and $7.2, \mathrm{H}_{2} \mathrm{PO}_{4}{ }^{-}$is the dominant species $(\mathrm{m}=2)$. Between $\mathrm{pH} 7.2$ and $12.3, \mathrm{HPO}_{4}{ }^{2-}$ is the dominant species $(\mathrm{m}=2)$. When an alkaline oxide — such as $\mathrm{MgO}$ - is stirred into an acid phosphate solution, the $\mathrm{pH}$ of the solution will slowly rise as acid is neutralized. As the $\mathrm{pH}$ rises above 2, formation of ceramics is initiated. The dissolution reaction of a metal oxide $\mathrm{MO}_{\mathrm{n}}$ in an acidic solution is shown in Equation (3.2):

$$
\mathrm{MO}_{\mathrm{n}}+2 \mathrm{nH}^{+}=\mathrm{M}^{2 \mathrm{n}+}(\mathrm{aq})+\mathrm{nH}_{2} \mathrm{O}
$$

where $\mathrm{M}$ is a metal of a valency $2 \mathrm{n}$, and (aq) indicates an aqueous ion. Dissolution of the metal oxide neutralizes protons, increasing the $\mathrm{pH}$ of the solution. This can lead to hydrolysis of some cations to 
produce species of the form $\mathrm{MOH}_{\mathrm{x}}{ }^{(2 \mathrm{n}-\mathrm{x})}(\mathrm{aq})$. Examples for $\mathrm{MgO}$ and $\mathrm{Al}_{2} \mathrm{O}_{3}$ include $\mathrm{Mg}(\mathrm{OH})^{+}, \mathrm{Al}(\mathrm{OH})^{2+}$ and $\mathrm{Al}(\mathrm{OH})_{2}{ }^{+}$. For the dissolution reaction given by Equation (3.3), the equilibrium constant $\mathrm{K}$ is defined as

$$
\mathrm{K}_{\mathrm{n}}=\left\{\mathrm{M}^{2 \mathrm{n}+}(\mathrm{aq})\right\} /\left\{\mathrm{MO}_{\mathrm{n}}\right\}\left\{\mathrm{H}^{+}\right\}
$$

where \{\} indicate activities of the species of interest. The equilibrium constant $K_{n}$ in Equation (3.3) provides a quantitative measure of the amount of dissolution of a particular oxide. This quantity determines whether a particular oxide satisfies the condition of slow dissolution and if CBPC will form in a given $\mathrm{pH}$ range. Monovalent metal oxides with the exception of $\mathrm{Ag}_{2} \mathrm{O}$ and $\mathrm{Cu}_{2} \mathrm{O}$ (such as those of alkali metals) are soluble in water; divalent oxides are generally sparsely soluble; trivalent oxides are even less soluble (with few exceptions such as yttria and bismuth oxide); and higher valent oxides are mostly insoluble. Therefore, monovalent oxides dissolve rapidly in the phosphate solution and form phosphate precipitates without forming monolithic ceramics. Sparsely soluble divalent oxides are most suitable for the formation of well-crystallized ceramics. Tri- and quadrivalent oxides do not dissolve sufficiently; hence, it has been difficult to form ceramics by their dissolution. These observations imply that oxides should exhibit a certain low level of solubility if they are to form ceramics. The solubility should not be too high to form a precipitate or too low to react insufficiently.

To evaluate the impact of metal oxide solubility, it is useful to express the solubility constant $\left(\mathrm{K}_{\mathrm{sp}}\right)$ in terms of a negative logarithm or $\mathrm{pK}_{\mathrm{sp}}=-\log \mathrm{K}_{\mathrm{sp}}$. For example, Pourbaix (1974) provides the following relationship for determining cation concentrations in acidic solution as a function of $\mathrm{pH}$ and $\mathrm{pK}_{\mathrm{sp}}$

$$
\log \left\{\mathrm{M}^{2 \mathrm{n}+}(\mathrm{aq})\right\}=\mathrm{pK}_{\mathrm{sp}}-2 \mathrm{n}(\mathrm{pH})
$$

Using this relationship, the aqueous solubility characteristics of several common divalent and trivalent oxides have been plotted as a function of $\mathrm{pH}$ in Figure 3.2 (from Wagh and Jeong 2003). For completeness of the solubility, profiles were extended into the alkaline region. Several conclusions may be drawn from Figure 3.2. For $\mathrm{pK}_{\mathrm{sp}}-2 \mathrm{n}(\mathrm{pH})>0,\left\{\mathrm{M}^{2 \mathrm{n}+}(\mathrm{aq})\right\}$ will be very large, implying rapid dissolution of the oxide. For controlled dissolution of the oxide and to form a ceramic, $2 \mathrm{n}(\mathrm{pH})$ must be $\geq \mathrm{pK}_{\mathrm{sp}}$. Thus, the minimum $\mathrm{pH}\left(\mathrm{pH}_{\min }\right)$ for formation of a ceramic is given by $\mathrm{pH}_{\min }=\mathrm{pK}_{\mathrm{sp}} / 2 \mathrm{n}$.

$\mathrm{CaO}$ does not satisfy this condition in the acidic region, and as a result it is not possible to form ceramics of $\mathrm{Ca}$ by an acid-base reaction. For this reason, hydroxyapatite $\left(\mathrm{Ca}_{5}\left(\mathrm{PO}_{4}\right)_{3} \mathrm{OH}\right)$, a major component of bone, is produced by an acid-base reaction between two sparsely soluble calcium phosphate salts such as tetracalcium phosphate $\left(\mathrm{Ca}_{4}\left(\mathrm{PO}_{4}\right)_{2} \mathrm{O}\right)$ and dibasic calcium phosphate $\left(\mathrm{CaHPO}_{4}\right)$ (Brown and Chow 1986). $\mathrm{MgO}$ comes close to satisfying this condition, but is still beyond the required $\mathrm{pH}$ range. As a result, formation of $\mathrm{MgO}$ ceramics has been possible only by reducing the reaction rate of $\mathrm{MgO}$ dissolution through calcination. $\mathrm{FeO}$ and $\mathrm{ZnO}$ are at the threshold of the range and it has been possible to form ceramics of these oxides often by calcination of $\mathrm{ZnO}$. Trivalent oxides, such as $\mathrm{Al}_{2} \mathrm{O}_{3}$ and $\mathrm{Fe}_{2} \mathrm{O}_{3}$, satisfy the condition that $2 \mathrm{n}(\mathrm{pH})$ must be $\geq \mathrm{pK}_{\text {sp }}$, but the solubility of $\mathrm{Al}_{2} \mathrm{O}_{3}$ and $\mathrm{Fe}_{2} \mathrm{O}_{3}$ is too low to form a ceramic. 


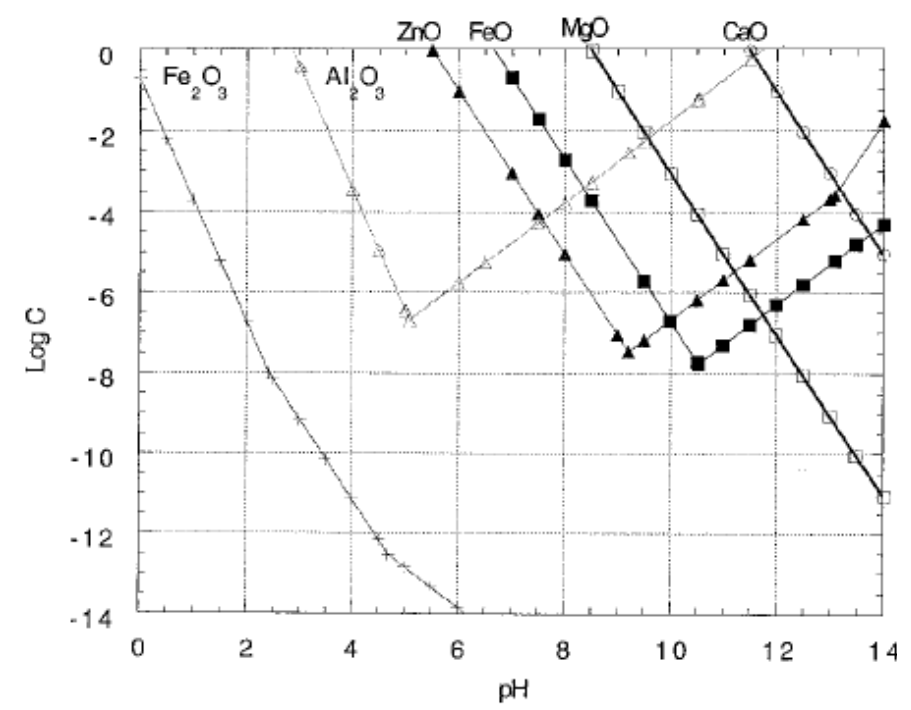

Figure 3.2. Aqueous Solubility Characteristics of Divalent and Trivalent Oxides as a Function of pH. Other solvents could form either labile or inert complexes with cation oxides (from Wagh and Jeong 2003).

Acid phosphates such as $\mathrm{NH}_{4} \mathrm{H}_{2} \mathrm{PO}_{4},\left(\mathrm{NH}_{4}\right)_{2} \mathrm{HPO}_{4} \cdot 2 \mathrm{H}_{2} \mathrm{O}$, and $\mathrm{KH}_{2} \mathrm{PO}_{4}$ have been used to form Mg-based phosphate ceramics. The $\mathrm{pH}$ of these phosphate salt solutions is 3.8, 2.3, and 4.1, respectively, at their saturation concentrations. These values are still lower than the $\mathrm{pH}_{\text {min }}$ needed for $\mathrm{MgO}$, which implies there would be a spontaneous dissolution of $\mathrm{MgO}$ in the solutions of these phosphates. Calcination of $\mathrm{MgO}$ helps control its dissolution; however, despite this pretreatment only small-size ceramics can be formed with $\mathrm{NH}_{4} \mathrm{H}_{2} \mathrm{PO}_{4}$ due to the low $\mathrm{pH}$ of the phosphate salt solution. A solution of $\left(\mathrm{NH}_{4}\right)_{2} \mathrm{HPO}_{4}$ with a sufficiently high $\mathrm{pH}$ of 7.2 may be used, but evolution of ammonia disrupts the formation of dense ceramics. Use of $\mathrm{KH}_{2} \mathrm{PO}_{4}$ does provide a high enough $\mathrm{pH}$ to form large-size ceramics that are dense and hard.

The requirement for formation of the aquosols (Figure 3.1b) is that the $\mathrm{pH}$ of the solution should be lower than the point of zero charge (PZC) of the oxide (Hunter 1981). Most of the divalent and trivalent metal oxides satisfy this condition in any acidic solution. For example, the PZCs for $\mathrm{MgO}, \mathrm{Al}_{2} \mathrm{O}$, and $\mathrm{Fe}_{2} \mathrm{O}_{3}$ are 12.0, 8.6, and 9.0, and hence should form aquosols in an acidic solution. The PZC for quadrivalent oxides is lower in general and therefore are not good candidates for forming CBPCs in a moderately acidic solution. For example, silica - with a PZC of 2.5-will not form aquosols in an acidic solution, unless the solution is highly acidic. The case for many other quadrivalent oxides is similar.

For ceramic formation to be uniform, it is necessary that the aquosol is well distributed in the solution. It is well known that condensed phosphates are excellent dispersants and hence, these aquosols are well dispersed in phosphate solution. In addition, constant mixing of the slurry during formation of the ceramics also helps in dispersing these sols.

As in the case of the sol-gel process (Brinker and Scherer 1989), dissolution of oxides in an acidic solution and their subsequent reaction leads to formation of a gel. Initially, isolated sols are formed and 
they remain in a colloidal state, but as more and more cations are released into the solution, further condensation occurs and these sols become connected. As chains of sols are formed, they percolate throughout the solution to form the gel.

In the case of the sol-gel process, the objective is to produce stable sols and its gel; however, in the case of CBPCs, an unstable sol is required. The desired outcome for CBPCs is for the acid-base reaction to be initiated between the sols and the phosphate anions to form the corresponding hydrophosphate salt. In the case of divalent oxides, such as $\mathrm{MgO}$, the acid-base reaction proceeds at room temperature and produces a room-temperature-setting ceramic. Thus, unstable sols will readily form a CBPC whereas stable ones do not. The gel is now converted to a saturated phosphate solution in which a significant amount of undissolved metal oxide particles remain and are uniformly distributed. The presence of undissolved metal oxide particles in the final ceramic is always detectable by XRD. As precipitation of the phosphates occur, these oxide particles form nuclei for crystallization and the entire gel condenses into a monolithic solid of CBPC. Thus, it is important that some unreacted particles are available to form a good stable ceramic. In addition to the crystalline phase, an amorphous phase is always detectable by $\mathrm{XRD}$ in these ceramics. Formation of this amorphous phase is dependent on the very fine particles that exist in the starter powders that dissolve completely in the acid solution, and also on the rate of dissolution of the oxide in the acid solution.

The dissolution rate of the oxides also plays a key role in the formation of ceramics. The rate of change of $\mathrm{pH}$ depends on the rate at which oxide powder is added to the solution during mixing; therefore, this is an external parameter that is controlled during operation. The rate will also depend on the surface morphology of the powder. Crystalline powders will dissolve more slowly than amorphous powders. Retardants (such as boric acid) have been used to reduce this rate. Retardants form unstable compounds that encapsulate the particles of the oxide powders and temporarily shield the grains from the acid solution, and retard the rate of availability of the oxides for dissolution (Sarkar 1991). Inasmuch as the condition for forming a ceramic requires that $2 \mathrm{n}(\mathrm{pH})$ is $\geq \mathrm{pKsp}$, most of the heat is generated at $\mathrm{pH}_{\min }$. At higher $\mathrm{pH}$, the heat evolution drops by a factor of 100 for each $\mathrm{pH}$ unit increase for divalent oxides, and by 1000 for trivalent oxides. Among the divalent oxides, $\mathrm{CaO}$ will produce the maximum heat, followed by $\mathrm{MgO}$. This explains why it has not been possible to make a ceramic of calcium hydrophosphate and why $\mathrm{MgO}$ needs pretreatment or reduction of the reaction to form a ceramic.

Because of their high solubility and dissolution rate, commercially available oxides of $\mathrm{Mg}$ tend to react spontaneously with acid phosphates and form precipitates rather than forming ceramics. However, these same oxides, when calcined at high temperatures (nearly $1300^{\circ} \mathrm{C}$ ), produce excellent ceramics. Eubank (1951) showed that calcination of $\mathrm{MgO}$ to $1300^{\circ} \mathrm{C}$ reduces porosity of individual grains and also increases particle size.

Further studies were conducted to determine the effect of calcination of $\mathrm{MgO}$ powder on its morphology and acid solubility (Wagh and Jeong 2003). Uncalcined commercial MgO powder was calcined at $1300^{\circ} \mathrm{C}$ for 3 hours and lightly crushed. Comparison of grain surfaces of the uncalcined powder with those of calcined MgO using SEM image analysis indicated that the uncalcined powder is covered with a powdery or microcrystalline substance whereas the same surface of the calcined powder is smooth, indicating reduction of the amorphous coating on the individual grains by crystallization. The particles of calcined powder also appeared bigger, indicating some grain growth due to the calcination process. The density of the calcined powders was increased from 3.36 to $3.57 \mathrm{~g} / \mathrm{cm}^{3}$, while the surface 
area was reduced from 33.73 to $0.34 \mathrm{~cm}^{2} / \mathrm{g}$. This significant reduction in surface area is the reason for the reduction in the solubility of the $\mathrm{MgO}$ powder. XRD analysis also indicated an increase in crystallinity for the calcined powders.

To investigate the effect of calcination of the $\mathrm{MgO}$ powder on its solubility, a dissolution study in $\mathrm{H}_{3} \mathrm{PO}_{4}$ solution was conducted (Wagh and Jeong 2003). The change in $\mathrm{pH}$ as a function of time for both calcined and uncalcined $\mathrm{MgO}$ powders is shown in Figure 3.3. During the first 10 minutes, the $\mathrm{pH}$ of the solution of uncalcined $\mathrm{MgO}$ increased from 1.5 to 5, whereas that of the calcined $\mathrm{MgO}$ increased from 1.5 to only 2. Initially, the rate of change of $\mathrm{pH}$ for uncalcined $\mathrm{MgO}$ is extremely sharp, but within minutes is reduced dramatically. The rate of change of $\mathrm{pH}$ for calcined $\mathrm{MgO}$ is small but significant and virtually constant. The very high initial rate of $\mathrm{pH}$ change for uncalcined powder is due to dissolution and subsequent reaction of amorphous $\mathrm{MgO}$. The reaction products in this case will coat individual grains and prevent further dissolution of the powder. Once calcined, this amorphous $\mathrm{MgO}$ crystallizes and reduces the early rate of dissolution, allowing a slow but constant rate of dissolution throughout the test period. These observations explain why the solubility of calcined $\mathrm{MgO}$ is reduced and why calcined powder reacts slowly during formation of the phosphate ceramic.

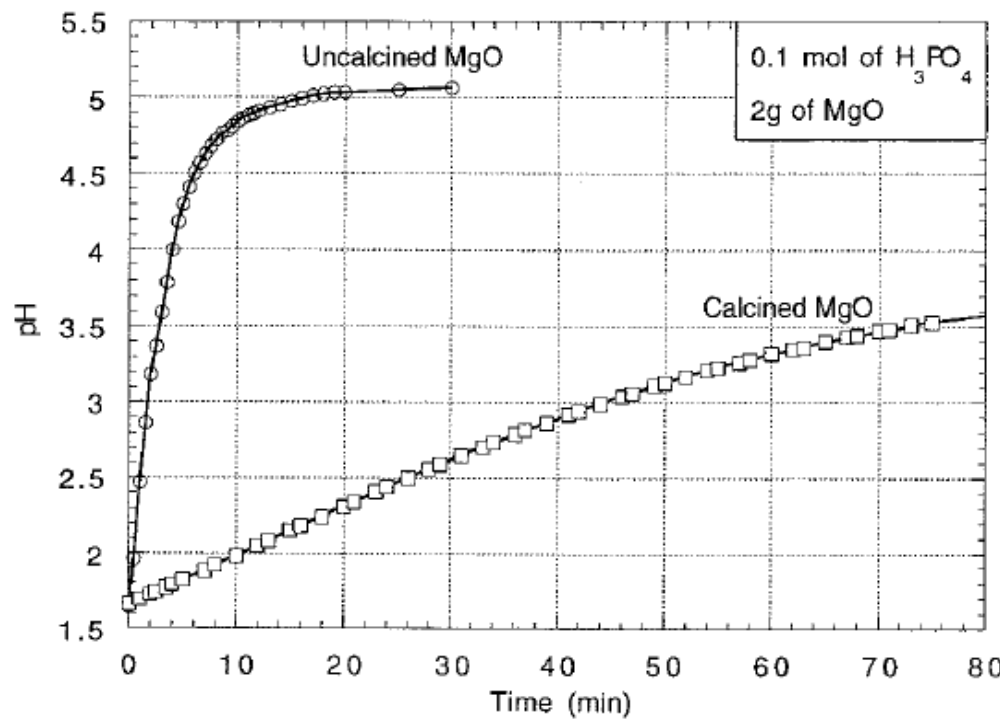

Figure 3.3. Increase in $\mathrm{pH}$ with Time During Neutralization of Calcined and Uncalcined $\mathrm{MgO}$ (from Wagh and Jeong 2003)

In large batches, the mixing time is only a few minutes before the exothermic acid-base reaction begins between $\mathrm{MgO}$ and $\mathrm{H}_{3} \mathrm{PO}_{4}$ or an acid phosphate, even with precalcined powders. Therefore, chemical retardants are needed in large-scale mixing operations (Sakar 1991). Boric acid is used for this purpose. When small quantities of boric acid $(<1 \%$ of $\mathrm{MgO})$ is added to the mixture, a coating develops on the $\mathrm{MgO}$ particles and retards early dissolution and delays the acid-base reaction. Sarkar (1991) studied the kinetics of reaction between $\mathrm{MgO}$ and ammonium phosphate in the presence of boric acid and reported that boric acid aids the development of a polymeric coating on the $\mathrm{MgO}$ grains and thus retards the setting rate. Wagh and Jeong (2003) conducted XRD and DTA to identify the phase of the coating on phosphate ceramics that formed during reaction between $\mathrm{MgO}$ and $\mathrm{H}_{3} \mathrm{PO}_{4}$ when 1 wt.\% boric acid was added. Addition of the boric acid retarded the reaction time from 1.5 to $4.5 \mathrm{~h}$. The polymeric coating on 
the $\mathrm{MgO}$ particles was identified as lunebergite $\left(\mathrm{Mg}_{3} \mathrm{~B}_{2}\left(\mathrm{PO}_{4}\right)_{2}(\mathrm{OH})_{6} \cdot 6 \mathrm{H}_{2} \mathrm{O}\right)$ using XRD and confirmed by DTA. Identification of this phase implies the following mechanism for retardation of the reaction. When boric acid-containing $\mathrm{MgO}$ is mixed into the phosphate solution, lunebergite forms on the grains of the $\mathrm{MgO}$ as a coating. This prevents dissolution of the grains in the acid solution. Subsequently, as the $\mathrm{pH}$ of the solution rises, the coating slowly dissolves back into the solution and exposes the grains to the acid solution. 


\subsection{Ceramicrete Production Description}

Ceramicrete fabrication steps and processing equipment needs are simple with low overall processing costs. Ceramicrete fabrication and processing equipment needs are very similar to those used for production of cement waste forms. Fabrication is conducted at room temperature and the entire stabilization reaction occurs within hours. The short setting time is particularly advantageous for radioactive wastes because it minimizes worker exposure. The raw materials required for fabricating the waste forms are readily available at comparatively low cost.

As input to the low-temperature immobilization study of potential secondary waste forms including Ceramicrete (Russell et al. 2006), CH2M HILL developed a concept for a standalone facility for implementing the Ceramicrete process for Hanford secondary liquid wastes. The following summarizes that concept.

\subsection{Ceramicrete Process Description}

The main steps in the Ceramicrete concept for Hanford secondary liquid wastes include

1. Liquid waste receipt

2. Partial neutralization

3. Getters and reducing agent addition

4. Partial dewatering by evaporation

5. Mixing waste solution and Ceramicrete dry materials

6. Waste form curing and storage

Figure 4.1 shows the conceptual flow diagram to implement this process. The liquid secondary wastes would be received into one of two tanks. One of the tanks is used to receive the wastes while the other is transferring its contents to the neutralization vessel.

In the neutralization tank, phosphoric acid is added to neutralize the caustic secondary wastes to a $\mathrm{pH}$ of approximately 5. The neutralization step is exothermic and the resulting heat will need to be dissipated. This neutralization step may or may not be necessary in the process. In more recent laboratory testing with simulated Hanford secondary wastes, the neutralization step is not included. Following the neutralization step, if used, stannous chloride $\left(\mathrm{SnCl}_{2}\right)$ is added to reduce technetium to the less mobile +4 oxidation state, and silver zeolite is added to capture iodine within the zeolite cage structure.

The next step is to dewater the aqueous waste solution using a vacuum evaporator. This step is intended to minimize the volume of the final Ceramicrete waste form. The extent of evaporation would have to be optimized with respect to equipment and energy costs relative to the savings in materials and disposal costs. Two evaporator condensate tanks are included to allow for one vessel to be sampled and discharged while the other is receiving the evaporator condensate. 


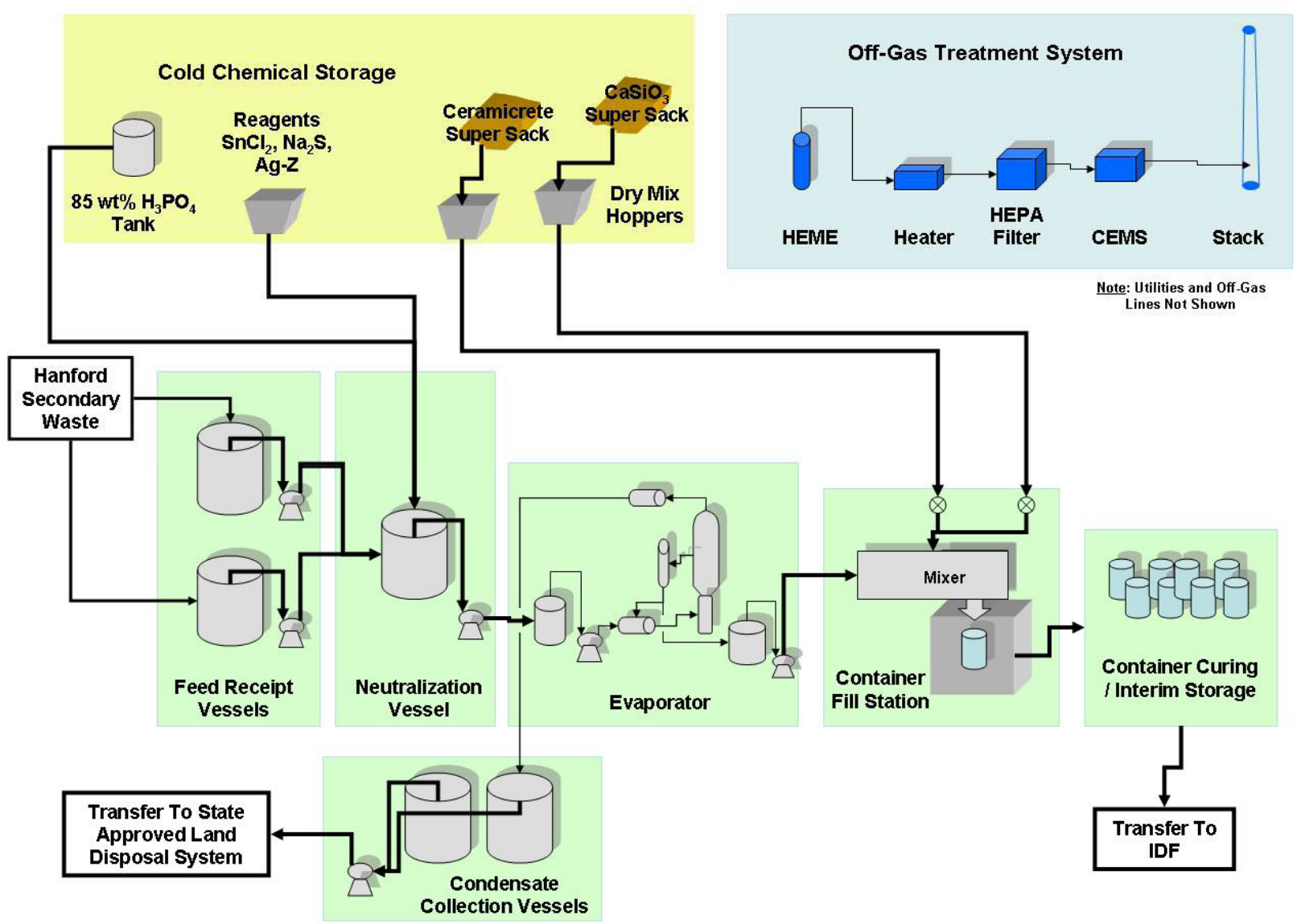

Figure 4.1. Conceptual Flow Diagram for Ceramicrete Process (from Russell et al. 2006)

The concentrated waste solution is then transferred to a mixer for blending the with the Ceramicrete dry materials including the magnesium oxide, mono potassium phosphate, and filler material. The ingredients are mixed in a batch in a mixer and are discharged into the waste form container. Mixing times are on the order of 20 to 30 minutes. The mixer is sized delivery to a single waste form container volume. A $2.04 \mathrm{~m}^{3}$ box is proposed as a compromise between minimizing the number of containers produced on a daily basis and allowing for heat dissipation during the Ceramicrete curing process.

The Ceramicrete should set within a couple of hours and should be cured within 24 hours although heat dissipation may take longer depending on the size of the containers. Storage will be needed for the curing process and interim storage will be needed until the containers can be received in IDF.

Ancillary systems include chemical storage for the dry materials including the getters and Ceramicrete ingredients and a storage tank for the phosphoric acid for neutralizing the caustic secondary wastes. An off gas treatment system would also be required.

\subsection{Equipment List and Sizing}

As part of their Ceramicrete facility concept, CH2MHILL provided an equipment list for the major equipment components (Russell et al. 2006). The equipment is sized to process a maximum volume of 
800,000 liters of $2 \mathrm{M}$ sodium secondary waste solution every 30 days with a 70 percent total operating efficiency. All vessels are sized to hold their contents at 85 percent capacity. Table 4.1 provides the equipment list and vessel sizes.

Table 4.1. Major Equipment List for Conceptual Ceramicrete Facility (from Russell et al. 2006)

\begin{tabular}{|c|c|c|}
\hline Equipment & Quantity & $\begin{array}{l}\text { Maximum } \\
\text { Capacity }\end{array}$ \\
\hline Waste Receipt Vessel (stainless steel) & 2 & $4000 \mathrm{gal}$ \\
\hline Transfer Pump & 2 & $100 \mathrm{gpm}$ \\
\hline Phosphoric Acid Storage Tank (carbon steel) & 1 & 200 gal \\
\hline Transfer Pump & 1 & 0 to $5 \mathrm{gpm}$ \\
\hline Neutralization/Getter Addition Vessel (stainless steel) & 1 & $2,200 \mathrm{gal}$ \\
\hline Transfer Pump & 1 & $100 \mathrm{gpm}$ \\
\hline Dry Getter Material Hopper (carbon steel) & 3 & 100 gal \\
\hline Pneumatic Transfer & 3 & 0.5 to $2 \mathrm{~kg} / \mathrm{mimute}$ \\
\hline Evaporator Feed Vessel (stainless steel) & 1 & 500 gal \\
\hline Transfer Pump & 1 & 0 to $10 \mathrm{gpm}$ \\
\hline Evaporator Concentrate Vessel (stainless steel) & 1 & 500 gal \\
\hline Transfer Pump & 1 & 0 to $10 \mathrm{gpm}$ \\
\hline Evaporator - Reboiler (stainless steel) & 1 & TBD BTU/hour \\
\hline Vapor-Liquid Separator Vessel & 1 & $1000 \mathrm{gal}$ \\
\hline Recirculation Pump & 1 & $\sim 10,000 \mathrm{gpm}$ \\
\hline Concentrate Pump & 1 & 0 to $10 \mathrm{gpm}$ \\
\hline Primary Condenser & 1 & TBD BTU/hour \\
\hline Secondary Condenser & 1 & TBD BTU/hour \\
\hline Process Condensate Vessel (stainless steel) & 2 & $5,300 \mathrm{gal}$ \\
\hline Transfer Pump & 2 & $100 \mathrm{gpm}$ \\
\hline Dry Filler Material Hopper (carbon steel) & 1 & 1,000 gal \\
\hline Pneumatic Transfer & 1 & 0 to $6 \mathrm{~kg} /$ minute \\
\hline Ceramicrete Pre-Mix Hopper (carbon steel) & 1 & 3,300 gal \\
\hline Pneumatic Transfer & 1 & 0 to $20 \mathrm{~kg} /$ minute \\
\hline Ceramicrete Ribbon-Type Mixer (carbon steel) & 1 & $2.04 \mathrm{~m}^{3} / \mathrm{batch}$ \\
\hline Container Storage Area with Overhead Crane & 1 & 36 containers \\
\hline Underground Pipeline & & $4,500 \mathrm{ft}$ \\
\hline Dust Bag House & 1 & TBD \\
\hline Process Off-Gas Treatment System & 1 & TBD \\
\hline Facility Off-Gas Treatment System & 1 & TBD \\
\hline Distributive Control System & 1 & $\mathrm{~N} / \mathrm{A}$ \\
\hline Office/Control Room Area & 1 & $1,000 \mathrm{ft}^{2}$ \\
\hline
\end{tabular}

\subsection{Existing Facilities and Cost Data}

Currently, there are no pilot-scale or full-scale Ceramicrete plants either under construction or in operation. Therefore operation costs are not available.

Schwinkendorf and Cooley (1999) conducted an economic evaluation of various treatment technologies available for mixed wastes in the DOE complex. It was concluded that Ceramicrete is one of the 
most economical methods currently available to treat these wastes. The material costs for Ceramicrete are about 50\% higher than Portland cement (Wagh et al. 1999a).

Construction costs for the conceptual process design for the Ceramicrete Treatment Facility (CTF) described in the previous section were estimated by CH2MHILL. Based on this conceptual design, the estimated cost for construction of the CTF for immobilizing HSW was estimated to be $\$ 48.5$ million (in 2005 dollars). Table 4.2 lists the major cost elements. Additional details are provided in the Russell document.

Table 4.2. Estimated Construction Costs for a Hanford Ceramicrete Facility (from Russell et al. 2006)

\begin{tabular}{lc}
\hline \multicolumn{1}{c}{ Cost Element } & Cost $(2005 \$)$ \\
\hline Other Project Costs & $\$ 7.852 \mathrm{M}$ \\
Engineering Support & $\$ 0.687 \mathrm{M}$ \\
Design & $\$ 2.410 \mathrm{M}$ \\
Procurement & $\$ 8.363 \mathrm{M}$ \\
Installation & $\$ 12.359 \mathrm{M}$ \\
Readiness / Startup & $\$ 0.669 \mathrm{M}$ \\
Subtotal & $\$ 32.340 \mathrm{M}$ \\
Contingency (50 Percent) & $\$ 16.170 \mathrm{M}$ \\
Total & $\$ \mathbf{4 8 . 5 1 0 M}$ \\
\hline
\end{tabular}




\subsection{Ceramicrete Physical Properties}

In this section, physical properties measurements of the Ceramicrete waste form are discussed. Properties discussed include heat of reaction, porosity, and density.

\subsection{Heat of Reaction}

The enthalpy of reaction for equation 1 is exothermic with $66.8 \mathrm{~kJ} / \mathrm{mol}\left(\mathrm{MgKPO}_{4} \cdot 6 \mathrm{H}_{2} \mathrm{O}\right)$ of heat released during the reaction (Singh et al. 2006). The release of heat as a result of this reaction must be considered when designing the size and geometry of the waste form such that excessive heating of the waste form does not occur during the ceramic setting process. As indicated in Section 4.0, Ceramicrete waste forms fabricated at the 55-gal scale resulted in a maximum temperature increase of $82^{\circ} \mathrm{C}$ (Wagh et al. 2001).

\subsection{Porosity and Density}

Selected density and porosity measurements conducted on Ceramicrete waste forms are shown in Table 5.1. Data in the table are from waste forms fabricated with liquid waste streams that have similar compositions, at least in some respects, to expected HSW compositions as well as recent data for waste forms fabricated with WTP secondary waste stream simulants (Singh et al. 2011). Data compiled in the table that have both density and porosity measurements include waste forms made with the MKP binder only (Wagh et al. 1999a), Hanford Site tank supernatant waste simulant (Wagh et al. 2003), and ${ }^{99}$ Tc eluent waste simulant (Singh et al. 2006). Additional data for which only density measurements are available include the following:

- waste forms made with surrogate salt waste (Wagh et al. 2001)

- WTP HSW simulant and Idaho Nuclear Technology and Engineering Center (INTEC) sodiumbearing waste (SBW) simulants (Russell et al. 2006)

- Hanford Site tank supernatant waste and Mayak supernatant waste simulant (Vinokurov et al. 2009)

- Waste forms fabricated with WTP secondary waste stream simulants (Singh et al. 2011).

The range in density observed for these waste forms ranged from 1.64 to $2.08 \mathrm{~g} / \mathrm{cm}^{3}$. The density of the MKP binder itself with no waste was $1.7 \mathrm{~g} / \mathrm{cm}^{3}$. The porosity range for the limited measurements made on the waste forms was $4.0 \%$ to $7.9 \%$. The porosity of the MKP binder itself was $2.9 \%$. These measurements indicate that addition of waste to the MKP binder results in an increase in both density and porosity. 
Table 5.1. Porosity and Density Measurements of Ceramicrete Waste Forms

\begin{tabular}{|c|c|c|c|c|}
\hline Waste Type/Loading & Actual Waste/Simulant/Spikes & Density $\left(\mathrm{g} / \mathrm{cm}^{3}\right)$ & Porosity \% & Reference \\
\hline None & $\mathrm{MgKPO}_{4} \cdot 6 \mathrm{H}_{2} \mathrm{O}$ binder only, no waste & 1.7 & 2.9 & Wagh et al. (1999a) \\
\hline $\begin{array}{l}\text { Surrogate salt waste }\left(\mathrm{NaNO}_{3} \text { and }\right. \\
\mathrm{NaCl}), 58 \text { and } 70 \text { wt.\% loading }\end{array}$ & $\begin{array}{l}\text { Both } \mathrm{NO}_{3}^{-} \text {and } \mathrm{Cl}^{-} \text {wastes contained } \mathrm{Fe}_{2} \mathrm{O}_{3}, \mathrm{Al}(\mathrm{OH})_{3} \text {, } \\
\mathrm{Na}_{3} \mathrm{PO}_{4}, \mathrm{Ca}_{2} \mathrm{SiO}_{4} \text {, and water as major components, } \mathrm{NaCl} \text {, } \\
\mathrm{CaSO}_{4}, \text { and } \mathrm{NaNO}_{3} \text { as salts; and } \mathrm{Pb} \mathrm{Cr}, \mathrm{Hg}, \mathrm{Cd} \text {, and } \mathrm{Ni} \\
\text { (up to } 800-900 \text { ppm) as heavy metals in each of the } \\
\text { contaminant oxides, tricloroethylene }\end{array}$ & $1.7-2.0$ & & Wagh et al. (2001) \\
\hline $\begin{array}{l}\text { Hanford tank supernatant waste } \\
\text { simulant, } 39.8 \text { wt.\% loading }\end{array}$ & $\begin{array}{l}17 \text { wt.\% } \mathrm{Na}, 11.5 \text { wt.\% } \mathrm{NO}_{3}{ }^{-}, \mathrm{pH}=13.7, \mathrm{Cs}, \mathrm{Ba}, \mathrm{Re}, \mathrm{Cd} \\
(2.3 \mathrm{ppm}), \mathrm{Cr}(938 \mathrm{ppm}), \mathrm{Ag}(11.5 \mathrm{ppm}), \mathrm{Pb}(37 \mathrm{ppm}), \\
\text { and } \mathrm{Zn}(7.04 \mathrm{ppm})\end{array}$ & 1.88 & 7.9 & Wagh et al. (2003) \\
\hline $\begin{array}{l}{ }^{99} \mathrm{Tc} \text { eluent waste simulant with } \\
\mathrm{SnCl}_{2} \text { stabilization, } 36 \text { wt.\% loading }\end{array}$ & $\begin{array}{l}1 \mathrm{M} \mathrm{NaOH}, 1 \mathrm{M} \text { ethylenediamine, } 0.005 \mathrm{M} \mathrm{Sn}(\mathrm{II}) \text {, } \\
20-150 \mathrm{ppm} \mathrm{Tc}\end{array}$ & 1.8 & 4 & Singh et al. (2006) \\
\hline WTP HSW simulant, 25.8 wt.\% & $\begin{array}{l}\mathrm{Na}(45.2 \mathrm{~g} / \mathrm{L}), \mathrm{CO}_{3}^{-2}(60 \mathrm{~g} / \mathrm{L}), \mathrm{NO}_{3}^{-}(1.12 \mathrm{~g} / \mathrm{L}), \mathrm{OH} \\
(1.6 \mathrm{~g} / \mathrm{L}), \mathrm{TOC}(13.9 \mathrm{~g} / \mathrm{L}), \mathrm{Al}(0.32 \mathrm{~g} / \mathrm{L}), \mathrm{Cr}, \mathrm{Ag}, \mathrm{Cd}, \mathrm{Re}, \\
\mathrm{I}, \mathrm{Hg}, \mathrm{Pb}\end{array}$ & 2.06 & & Russell et al. (2006) \\
\hline INTEC SBW simulant, 47.4 wt.\% & $\begin{array}{l}\mathrm{Na}(43.2 \mathrm{~g} / \mathrm{L}), \mathrm{NO}_{3}^{-}(269 \mathrm{~g} / \mathrm{L}), \mathrm{Al}(17.8 \mathrm{~g} / \mathrm{L}), \mathrm{SO}_{4}^{-2} \\
(5.15 \mathrm{~g} / \mathrm{L}), \mathrm{Ca}(1.46 \mathrm{~g} / \mathrm{L}), \mathrm{K}(6.8 \mathrm{~g} / \mathrm{L}), \mathrm{Cl}^{-}(1.15 \mathrm{~g} / \mathrm{L}), \mathrm{F}^{-} \\
(0.83 \mathrm{~g} / \mathrm{L}), \mathrm{B}, \mathrm{Mg}, \mathrm{Cr}, \mathrm{Mn}, \mathrm{Fe}, \mathrm{Cd}, \mathrm{Cs}, \mathrm{Ce}, \mathrm{Hg}, \mathrm{Pb}, \mathrm{Re}, \mathrm{I}\end{array}$ & 2.02 & & Russell et al. (2006) \\
\hline $\begin{array}{l}\text { Hanford tank supernatant waste } \\
\text { simulant, } 35 \text { wt. } \% \text { loading }\end{array}$ & $\begin{array}{l}256 \mathrm{~g} / \mathrm{l} \mathrm{Na}, 168 \mathrm{~g} / \mathrm{L} \mathrm{NO}_{3}^{-}, 113 \mathrm{~g} / \mathrm{L} \mathrm{NO}_{2}^{-}, 83.7 \mathrm{~g} / \mathrm{L} \mathrm{OH}^{-} \\
\mathrm{CO}_{3}^{-2}, \mathrm{Al}, \mathrm{Cl}^{\prime}, \mathrm{Cs}, \mathrm{Sr}, \mathrm{SO}_{4}^{-2}, \mathrm{Cr}, \mathrm{Pb}, \mathrm{Cd}, \mathrm{K}, \mathrm{Am}, \mathrm{Ce}, \mathrm{Pu} \\
\mathrm{Np}, \mathrm{Am}, \mathrm{Sr}, \mathrm{Cs}, \mathrm{Tc}, \mathrm{I}, \mathrm{Se}\end{array}$ & $1.6-1.7$ & & $\begin{array}{l}\text { Vinokurov et al. } \\
\text { (2009) }\end{array}$ \\
\hline $\begin{array}{l}\text { Mayak supernatant waste simulant, } \\
43 \text { wt.\% loading }\end{array}$ & $\begin{array}{l}296 \mathrm{~g} / 1 \mathrm{Na}, 99 \mathrm{~g} / \mathrm{L} \mathrm{NO}_{3}^{-}, 38 \mathrm{~g} / \mathrm{L} \mathrm{NO}_{2}^{-}, 91.5 \mathrm{~g} / \mathrm{L} \mathrm{OH}^{-}, \mathrm{Al} \\
\mathrm{Cl}^{-}, \mathrm{SO}_{4}^{-2}, \mathrm{Cr}, \mathrm{Cs}, \mathrm{Sr}, \mathrm{Tc}, \mathrm{I}, \mathrm{Se}\end{array}$ & 1.8 & & $\begin{array}{l}\text { Vinokurov et al. } \\
\text { (2009) }\end{array}$ \\
\hline $\begin{array}{l}\text { WTP secondary waste simulant, } \\
\text { baseline }\end{array}$ & $\begin{array}{l}1 \mathrm{M} \mathrm{Na}, 0.398 \mathrm{M} \mathrm{OH}^{-}, 0.328 \mathrm{M} \mathrm{NO}_{3}^{-}, 0.0939 \mathrm{M} \mathrm{Al}, \\
0.0939 \mathrm{TOC}, 0.0228 \mathrm{M} \mathrm{CO}_{3}^{-2}, 0.0225 \mathrm{M} \mathrm{Cl}^{-}, 0.012 \mathrm{M} \\
\mathrm{NO}_{2}^{-}, \mathrm{Si}, \mathrm{K}, \mathrm{PO}_{4}^{-3}, \mathrm{SO}_{4}^{-2}, \mathrm{~F}^{-}, \mathrm{Cr}, \mathrm{Ag}, \mathrm{As}, \mathrm{Cd}, \mathrm{Hg}, \mathrm{Pb}, \mathrm{Tc}, \mathrm{I}\end{array}$ & $1.84-2.07$ & & Singh et al. (2011) \\
\hline
\end{tabular}


Table 5.1. (contd)

\begin{tabular}{|c|c|c|c|c|}
\hline Waste Type/Loading & Actual Waste/Simulant/Spikes & Density $\left(\mathrm{g} / \mathrm{cm}^{3}\right)$ & Porosity $\%$ & Reference \\
\hline $\begin{array}{l}\text { WTP secondary waste simulant, } \\
\text { cluster } 1\end{array}$ & $\begin{array}{l}1 \mathrm{M} \mathrm{Na}, 0.435 \mathrm{M} \mathrm{OH}^{-}, 0.190 \mathrm{M} \mathrm{NO}_{3}^{-}, 0.114 \mathrm{M} \mathrm{Al}, 0.114 \\
\mathrm{M} \mathrm{TOC}, 0.0466 \mathrm{M} \mathrm{CO}_{3}^{-2}, 0.0217 \mathrm{M} \mathrm{Cl}^{-}, 0.0105 \mathrm{M} \mathrm{NO}_{2}^{-} \\
\mathrm{Si}, \mathrm{K}_{1} \mathrm{PO}_{4}^{-3}, \mathrm{SO}_{4}^{-2}, \mathrm{~F}^{-}, \mathrm{Cr}, \mathrm{Ag}, \mathrm{As}, \mathrm{Cd}, \mathrm{Hg}, \mathrm{Pb}, \mathrm{Tc}, \mathrm{I}\end{array}$ & $1.83-2.08$ & & Singh et al. (2011) \\
\hline $\begin{array}{l}\text { WTP secondary waste simulant, } \\
\text { cluster } 2\end{array}$ & $\begin{array}{l}1 \mathrm{M} \mathrm{Na}, 0.397 \mathrm{M} \mathrm{NO}_{3}^{-}, 0.245 \mathrm{M} \mathrm{OH}^{-}, 0.0922 \mathrm{M} \mathrm{Al} \\
0.0922 \mathrm{M} \mathrm{TOC}_{0} 0.0394 \mathrm{M} \mathrm{CO}_{3}^{-2}, 0.0383 \mathrm{M}, 0.0291 \mathrm{M} \mathrm{Cl}^{-} \\
\text {'Si, K, } \mathrm{PO}_{4}^{-3}, \mathrm{SO}_{4}^{-2}, \mathrm{~F}^{-}, \mathrm{Cr}, \mathrm{Ag}, \mathrm{As}, \mathrm{Cd}, \mathrm{Hg}, \mathrm{Pb}, \mathrm{Tc}, \mathrm{I}\end{array}$ & $1.72-2.08$ & & Singh et al. (2011) \\
\hline $\begin{array}{l}\text { WTP secondary waste simulant, } \\
\text { mixed waste }\end{array}$ & 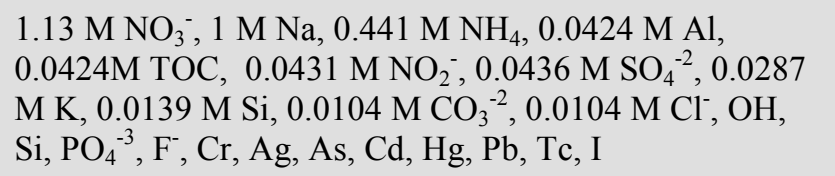 & $1.64-2.08$ & & Singh et al. (2011) \\
\hline
\end{tabular}




\subsection{Ceramicrete Performance}

Actual secondary waste streams will not be generated until the WTP is functioning. As a result, no waste forms with actual secondary wastes can be tested at this time. Recently, a study was completed on the performance of Ceramicrete waste form fabricated with WTP secondary waste stream simulants (Singh et al. 2011). In addition to this study, a number of studies have been published previously on the performance of Ceramicrete for stabilizing many waste constituents that will occur in secondary waste. Studies particularly useful for evaluating the performance of Ceramicrete with wastes streams that are similar to secondary waste streams are briefly summarized below.

Investigations of the effectiveness of Ceramicrete for various surrogate wastes, including one intended to represent the salt waste inventory within the DOE complex, have been reported by Wagh et al. (2001). The surrogate wastes used in these studies contained $\mathrm{Fe}_{2} \mathrm{O}_{3}, \mathrm{Al}(\mathrm{OH})_{3}, \mathrm{Na}_{3} \mathrm{PO}_{4}$, synthetic calcium silicate, and water as the major components; $\mathrm{NaCl}, \mathrm{CaSO}_{4}$, and $\mathrm{NaNO}_{3}$ as the salts; and $\mathrm{Pb}, \mathrm{Cr}$, $\mathrm{Hg}, \mathrm{Cd}$, and $\mathrm{Ni}$ (up to $800-900 \mathrm{ppm}$ ) as the heavy metals in each of the contaminant oxides.

Trichloroethylene was added to investigate if residual organics in the waste had any effect on the setting of the ceramic. The waste forms were fabricated at two waste loadings (58 and $70 \mathrm{wt} \%$ ) for each of the waste streams. TCLP leaching results demonstrated the hazardous contaminants were chemically immobilized and physically encapsulated within the Ceramicrete matrix. Density and compression strengths measured in the waste forms were also excellent.

Wagh et al. (2003) investigated stabilization of Hanford Site tank supernate simulants with Ceramicrete. The supernatant simulant contained $17 \% \mathrm{Na}, 11.5 \% \mathrm{NO}_{3}^{-}, \mathrm{Ag}, \mathrm{Cd}, \mathrm{Cr}, \mathrm{Cs}, \mathrm{Pb}, \mathrm{Zn}$, and $\mathrm{Re}$ as a surrogate for ${ }^{99} \mathrm{Tc}$, and a $\mathrm{pH}$ of 13.7 . At a waste loading of $40 \%$, it was demonstrated this waste stream was effectively stabilized.

Singh et al. (2006) studied the effectiveness of Ceramicrete for immobilizing ${ }^{99} \mathrm{Tc}$ in a waste stream that is generated by a process for separating ${ }^{99} \mathrm{Tc}$ from Hanford Site tank supernatant. A typical composition of this waste solution is $1 \mathrm{M} \mathrm{NaOH}, 1 \mathrm{M}$ ethylenediamine, $0.005 \mathrm{M} \mathrm{Sn}$ (II), and Tc as high as $150 \mathrm{ppm}$ or $0.0015 \mathrm{M}$. Two approaches were used to test Ceramicrete with this waste. In the first approach, the aqueous waste was stabilized directly by adding $38 \mathrm{wt} . \%$ fly ash and $2-3 \mathrm{wt} . \% \mathrm{SnCl}_{2}$ to the Ceramicrete binder. The optimal waste loading was 36 wt. $\%$. The concentrations of ${ }^{99} \mathrm{Tc}$ in these waste forms ranged from 20 to $150 \mathrm{ppm}$. In the second approach, the role of $\mathrm{SnCl}_{2}$ was investigated by adding $\mathrm{SnCl}_{2}$ to precipitate ${ }^{99} \mathrm{Tc}$ from the waste solution prior to fabricating the waste form. In this approach, the ${ }^{99} \mathrm{Tc}$ concentrations in the waste forms were as high as $900 \mathrm{ppm}$. The waste forms were prepared in an anoxic nitrogen atmosphere. The performance of the waste forms was determined through various strength, leaching, and durability tests. Test results indicated that ${ }^{99} \mathrm{Tc}$ was effectively stabilized in the Ceramicrete and the waste form was durable in an aqueous environment.

Russell et al. (2006) conducted a study to evaluate low-temperature technologies to immobilize mixed radioactive and hazardous waste. Specific target wastes for immobilization were 1) WTP HSW and 2) INTEC SBW. Three waste forms were studied including an alkali-aluminosilicate hydroceramic cement, Ceramicrete phosphate-bonded ceramic, and DuraLith alkali-aluminosilicate geopolymer. The waste forms were fabricated using simulants of a Hanford Site secondary waste and INTEC SBW. The resulting waste forms were characterized with respect to the TCLP, compressive strength tests (both irradiated [total exposure of $1 \times 10^{8} \mathrm{rad}$ ] and as-received samples), durability (American National Standards Institute [ANSI]/ANS) 16.1 leachability index [ANS 1986]), and modified PCT. 
Results reported in Russell et al. (2006) indicate that Ceramicrete met the TCLP Universal Treatment Standard in $40 \mathrm{CFR} 268.48$ for $\mathrm{Cr}, \mathrm{Cd}, \mathrm{Ag}, \mathrm{Hg}$, and $\mathrm{Pb}$ by more than an order of magnitude and the $3.45 \mathrm{MPa}$ compressive strength criteria by about an order of magnitude (radiation exposure made no difference in the strength). For the PCT using the standard sample preparation process, there was evidence the samples may be dissolving or otherwise breaking up during the wash step before the test itself was started. Russell et al. (2006) indicate that further work would be necessary to understand the waste-form behavior in the PCT, and to interpret the results with respect to waste-form performance in a disposal facility. Results of the ANSI/ANS 16.1 leachability index test method (ANS 1976) met the leachability index requirement for $\mathrm{Na}(\mathrm{LI}>6)$. Rhenium (used as a surrogate for $\mathrm{Tc}$ ) in waste forms fabricated with either of the two waste stream simulants did not meet the target index (LI>11), and no I was detected in the leachate. Additional waste forms prepared with HSW spiked at Re and I concentrations above the nominal simulant concentrations resulted in leachability indices of better than 11.0. It was concluded that based on the TCLP, compressive strength, and $\mathrm{Na}$ leachability index requirements that Ceramicrete showed potential as an effective low temperature immobilizing waste; however, its effectiveness for immobilizing relatively volatile radionuclides, including ${ }^{99} \mathrm{Tc}$ and ${ }^{129} \mathrm{I}$, could not be assessed without further testing. The ANSI/ANS 16.1 immersion test also revealed formulation issues that need to be addressed. Additional work has been performed to address these issues (Singh et al. 2011).

Performance of MKP waste forms fabricated with HLW simulants has been reported by Vinokurov et al. (2009). The wastes that were investigated include HLW simulants intended to represent liquid supernatants and sludges from Hanford Site tanks and Mayak (Russia). Novel procedures of solidification of HLW simulants were developed to increase stability of the MKP matrices to leaching radionuclides ( $\mathrm{Pu}, \mathrm{Np}, \mathrm{Am}, \mathrm{Cs}, \mathrm{Sr}, \mathrm{Tc}, \mathrm{I}$, and $\mathrm{Se})$, matrix-forming $\left(\mathrm{K}, \mathrm{Mg}\right.$, and $\left.\mathrm{PO}_{4}\right)$ and admixture components ( $\mathrm{NO}_{3}, \mathrm{NO}_{2}, \mathrm{Na}$, and others) as well as hazardous elements ( $\mathrm{Pb}, \mathrm{Cr}, \mathrm{Zn}$, and others) according to the ANS, PCT, and TCLP standards. Density $\left(\sim 1.7 \mathrm{~g} / \mathrm{cm}^{3}\right)$, compressive strength ( $\left.>20 \mathrm{MPa}\right)$, radiation resistance of the matrices, and chemical yield of radiolytic hydrogen $\left(0.004\right.$ molecule $\left.\mathrm{H}_{2} / 100 \mathrm{eV}\right)$ were determined.

In another study, Ceramicrete waste forms were fabricated using high concentrations $\left(25 \mathrm{~g} / \mathrm{dm}^{3}\right)$ of metal [Cd(II), $\mathrm{Cr}(\mathrm{III}), \mathrm{Cu}(\mathrm{II}), \mathrm{Ni}(\mathrm{II}), \mathrm{Pb}(\mathrm{II})$, and $\mathrm{Zn}(\mathrm{II})$ ] nitrate solutions (Buj et al. 2009, 2010). Metal leachability and waste form strength tests indicated that in all cases the metals were effectively stabilized.

In a recently published document (Singh et al. 2011), Ceramicrete waste forms were fabricated with four WTP secondary waste effluent simulants and tested for physical properties and performance. The four WTP secondary waste effluent simulants used were baseline caustic scrubber, low salt, high salt, and mixed (caustic scrubber blended with 10\% submerged bed scrubber waste stream). The baseline, cluster 1, cluster 2, and mixed waste streams are referred to as "B," "C1," "C2," and "M," respectively. Various Ceramicrete waste form formulations were produced by varying the quantities of the base ingredients, type, and quantities of powder fillers and additives, and waste loadings. Powder fillers used include class $\mathrm{C}$ fly ash, calcium silicate (wollastonite), and blast furnace slag. Additives used include boric acid, tin chloride $\left(\mathrm{SnCl}_{2}\right)$, Ag-loaded zeolite, and potassium sulfide $\left(\mathrm{K}_{2} \mathrm{~S}\right)$. Specific compositional details of the individual waste forms are available in Singh et al. (2011).

Further details of the results discussed above are provided in Sections 5.0 and 7.0. 


\subsection{Waste Acceptance Criteria}

\subsection{Void Space}

Void space measuremt data for scaled-up monoliths are not currently available. These data will be available once the engineering-scale monolith task is completed.

\subsection{Surface Dose Rate}

Proposed dose rate limits for wastes to be accepted into the IDF include a constraint that containers have surface dose rates less than or equal to $2 \mathrm{mSv}$ per hour (200 mrem per hour) at contact and less than $1 \mathrm{mSv}$ per hour (100 mrem per hour) at $30 \mathrm{~cm}$ (11.8 in.) (RPP-8402 2005). As part of a conceptual design report for a Supplemental Treatment Unit to be added to the ETF, a dose calculation was performed as input to design of the facility (Fluor Hanford 2005). The dose rate calculation considered waste streams from the WTP, DB3, supplemental treatment using bulk vitrification, and Basin 42 . The highest dose rate was from radionuclides in the DB3 waste stream. A 4- $\mathrm{ft} \times 4$ - $\mathrm{ft} \times 4$ - $\mathrm{ft}$ concrete block with a specific density of 1.5 was assumed as the waste form. The specific density is conservative because more dense materials provide more shielding. There is no indication whether or not the calculation included a container for the waste form block.

A dose rate of $1.25 \mathrm{mrem}$ per hour $(0.0125 \mathrm{mSv}$ per hour) was calculated at $1 \mathrm{in}$. from the block side, and 0.75 mrem per hour $(7.5 \mathrm{mSv}$ per hour) was calculated at $1 \mathrm{ft}$ from the side of the waste form block.

The ETF will not accept wastes for treatment with radionuclide concentrations above its design basis and administrative controls. Wastes treated and solidified in ETF will not exceed the IDF dose rate limits.

\subsection{Free Liquids}

One of the IDF WAC requirements is the waste form shall contain no detectable free liquids as defined in SW-846 Method 9095. Because water introduced in the formulation or waste is bound as water of hydration, the Ceramicrete fabrication process does not produce free liquids when correctly formulated. If excessive water occurs in the waste stream, dewatering can be used to reduce waste volume; this can be done at $70^{\circ} \mathrm{C}$ (Russell et al. 2006).

None of the waste forms fabricated with simulated WTP secondary waste had any observable free liquids (Singh et al. 2011). Free liquids were also not observed in any of the Ceramicrete waste forms fabricated with wastes that had compositions similar to secondary waste streams.

\subsection{Dangerous Waste Limitations - Toxicity Characteristic Leaching Procedure}

TCLP results for Ceramicrete waste forms fabricated with wastes relevant to secondary waste streams are shown in Table 7.1. These TCLP results include data compiled for waste forms made with Hanford Site tank supernatant waste simulant (Wagh et al. 2003); WTP HSW simulant and INTEC SBW simulants (Russell et al. 2006); and Hanford Site tank supernatant waste and Mayak supernatant waste simulant (Vinokurov et al. 2009). In all cases, the concentrations measured in the TCLP leachates were 
well below the Universal Treatment Standard limits. TCLP results for Ceramicrete waste forms fabricated with simulated WTP secondary waste streams are shown in Table 7.2 (Singh et al. 2011). Results with $<$ indicate concentrations below the detection limit. The waste form compositions, simulated WTP secondary waste stream compositions, and waste loadings are available in (Singh et al. 2011). In all cases, the concentrations measured in the TCLP leachates were well below the Universal Treatment Standard limits. TCLP results for waste forms with fly ash had detectable levels of $\mathrm{Cr}$ and Se. Results for waste forms fabricated with mixed waste simulants, where appropriate amounts of $\mathrm{Ag}$ and $\mathrm{Cd}$ were present in the simulant, were below the detection limit. $\mathrm{Pb}$ was also below detection limit values. These results indicate that containments of RCRA metals are effective for all Ceramicrete formulations studied at metal concentrations.

\subsection{Ignitibility}

Because nitrate waste is ignitable, it is required that waste forms be nonflammable for safe transport and storage. Wagh et al. (2001) conducted ignitability tests on waste forms fabricated with surrogate salt waste containing nitrate using a procedure recommended by EPA (1995) to demonstrate that CBPC waste forms comply with this requirement. Results of the testing implied that salt waste solidified with CBPCs will not require any special packaging because their inorganic ceramic composition inhibits the spread of flames, indicating they are excellent solidification media for flammable salt waste.

\subsection{Radiolysis}

Radioactive fission product isotopes emit $\beta$ and $\gamma$ radiation while actinides also emit $\alpha$ radiation. When radioactive components are solidified within a waste form, self-radiation of the matrix can result in radiolysis of water or organic compounds present in the waste form. This can cause production of gases, such as hydrogen, that can result in pressurization of waste form containers during storage.

Wagh et al. (1999b) conducted a feasibility study of Ceramicrete stabilization of Rocky Flats Pu-contaminated ash. As part of this work, hydrogen generation was measured in waste forms containing various waste types and wt.\% $\mathrm{Pu}$ (Table 7.3). Results indicate that the $\mathrm{G}$ value (quantity of $\mathrm{H}_{2}$ generated per $100 \mathrm{eV}$ of absorbed energy (assuming 100\% of the decay energy is absorbed in the waste form) ranged from 0.10 to 31.8. Based on these results, Wagh et al. (1999b) determined that gas yield was minimal and did not result in pressurization of the waste container, concluding that hydrogen generation resulting from radiolytic decomposition of water and organic compounds in the waste was not a significant issue.

In a study of HLW immobilization in Ceramicrete, Vinokurov et al. (2009) measured radiolytic generation of hydrogen. Measurements were conducted on a waste form fabricated with $1.1 \mathrm{wt} . \%{ }^{239} \mathrm{Pu}$. During a 4-week period, the radiation absorbed dose of the waste form was $5.0 \times 10^{8} \mathrm{rad}$. The quantity of radiolytic hydrogen released was $0.004 \mathrm{H}_{2}$ molecules $/ 100 \mathrm{eV}$.

Because significant quantities actinides are not expected to occur in the secondary waste stream, the impact of radiolysis on waste forms fabricated with secondary waste are expected to be much less than the above mentioned examples. Therefore, hydrogen generation resulting from radiolytic decomposition of water and organic compounds in Ceramicrete fabricated with secondary waste is not expected to be a significant issue. 
Table 7.1. TCLP Results for Ceramicrete Waste Forms Fabricated with Wastes Relevant to Secondary Waste Streams

\begin{tabular}{|c|c|c|c|c|c|c|}
\hline Waste Type/Loading & Actual Waste/Simulant/Spikes & Test Method & Component & $\begin{array}{l}\text { Leachate Concentration } \\
\qquad(\mathrm{mg} / \mathrm{L})\end{array}$ & $\begin{array}{l}\text { UTS Limit } \\
(\mathrm{mg} / \mathrm{L})\end{array}$ & Reference \\
\hline $\begin{array}{l}\text { Hanford tank } \\
\text { supernatant waste } \\
\text { simulant, } 39.8 \text { wt.\% } \\
\text { loading }\end{array}$ & $\begin{array}{l}17 \text { wt.\% } \mathrm{Na}, 11.5 \text { wt.\% } \mathrm{NO}_{3}^{-} \text {, } \\
\text { pH=13.7, } \mathrm{Cs}, \mathrm{Ba}, \mathrm{Re}, \mathrm{Cd} \\
(2.3 \mathrm{ppm}), \mathrm{Cr}(938 \mathrm{ppm}), \mathrm{Ag} \\
(11.5 \mathrm{ppm}), \mathrm{Pb}(37 \mathrm{ppm}) \text {, and } \\
\mathrm{Zn}(7.04 \mathrm{ppm})\end{array}$ & & $\begin{array}{l}\mathrm{Cd} \\
\mathrm{Cr} \\
\mathrm{Ag} \\
\mathrm{Pb} \\
\mathrm{Zn}\end{array}$ & $\begin{array}{r}<0.01 \\
0.01 \\
<0.05 \\
<0.05 \\
<0.05\end{array}$ & $\begin{array}{l}0.11 \\
0.6 \\
0.14 \\
0.75 \\
4.3\end{array}$ & $\begin{array}{l}\text { Wagh et al. } \\
(2003)\end{array}$ \\
\hline $\begin{array}{l}\text { WTP HSW simulant, } \\
25.8 \text { wt. } \%\end{array}$ & $\begin{array}{l}\mathrm{Na}(45.2 \mathrm{~g} / \mathrm{L}), \mathrm{CO}_{3}^{-2}(60 \mathrm{~g} / \mathrm{L}) \\
\mathrm{NO}_{3}^{-}(1.12 \mathrm{~g} / \mathrm{L}), \mathrm{OH}^{-}(1.6 \mathrm{~g} / \mathrm{L}) \\
\mathrm{TOC}(13.9 \mathrm{~g} / \mathrm{L}), \mathrm{Al}(0.32 \mathrm{~g} / \mathrm{L}) \\
\mathrm{Cr}, \mathrm{Ag}, \mathrm{Cd}, \mathrm{Re}, \mathrm{I}, \mathrm{Hg}, \mathrm{Pb}\end{array}$ & & $\begin{array}{l}\mathrm{Cr} \\
\mathrm{Cd} \\
\mathrm{Ag} \\
\mathrm{Hg} \\
\mathrm{Pb}\end{array}$ & $\begin{array}{r}0.0533 \\
<0.00028 \\
0.00779 \\
<0.00766 \\
0.00964\end{array}$ & $\begin{array}{l}0.60 \\
0.11 \\
0.14 \\
0.025 \\
0.75\end{array}$ & $\begin{array}{l}\text { Russell et al. } \\
(2006)\end{array}$ \\
\hline $\begin{array}{l}\text { INTEC SBW } \\
\text { simulant, } 47.4 \text { wt. } \%\end{array}$ & $\begin{array}{l}\mathrm{Na}(43.2 \mathrm{~g} / \mathrm{L}), \mathrm{NO}_{3}^{-}(269 \mathrm{~g} / \mathrm{L}) \\
\mathrm{Al}(17.8 \mathrm{~g} / \mathrm{L}), \mathrm{SO}_{4}^{-2}(5.15 \mathrm{~g} / \mathrm{L}) \\
\mathrm{Ca}(1.46 \mathrm{~g} / \mathrm{L}), \mathrm{K}(6.8 \mathrm{~g} / \mathrm{L}), \mathrm{Cl}^{-} \\
(1.15 \mathrm{~g} / \mathrm{L}), \mathrm{F}^{-}(0.83 \mathrm{~g} / \mathrm{L}), \mathrm{B}, \mathrm{Mg} \\
\mathrm{Cr}, \mathrm{Mn}, \mathrm{Fe}, \mathrm{Cd}, \mathrm{Cs}, \mathrm{Ce}, \mathrm{Hg}, \mathrm{Pb} \\
\mathrm{Re}, \mathrm{I}\end{array}$ & & $\begin{array}{l}\mathrm{Cr} \\
\mathrm{Cd} \\
\mathrm{Ag} \\
\mathrm{Hg} \\
\mathrm{Pb}\end{array}$ & $\begin{array}{r}<0.0018 \\
<0.00028 \\
0.00345 \\
<0.00766 \\
0.00147\end{array}$ & $\begin{array}{l}0.60 \\
0.11 \\
0.14 \\
0.025 \\
0.75\end{array}$ & $\begin{array}{l}\text { Russell et al. } \\
(2006)\end{array}$ \\
\hline $\begin{array}{l}\text { Hanford tank } \\
\text { supernatant waste } \\
\text { simulant, } 35 \text { wt. } \% \\
\text { loading }\end{array}$ & $\begin{array}{l}256 \mathrm{~g} / \mathrm{L} \mathrm{Na}, 168 \mathrm{~g} / \mathrm{L} \mathrm{NO}_{3}^{-} \\
113 \mathrm{~g} / \mathrm{L} \mathrm{NO}{ }^{-}, 83.7 \mathrm{~g} / \mathrm{L} \mathrm{OH}^{-} \\
\mathrm{CO}_{3}, \mathrm{Al}, \mathrm{Cl}, \mathrm{Cs}, \mathrm{Sr}, \mathrm{SO}_{4}^{-2}, \mathrm{Cr} \\
\mathrm{Pb}, \mathrm{Cd}, \mathrm{K}, \mathrm{Am}, \mathrm{Ce}, \mathrm{Pu}, \mathrm{Np}, \mathrm{Am}, \\
\mathrm{Sr}, \mathrm{Cs}, \mathrm{Tc}, \mathrm{I}, \mathrm{Se}\end{array}$ & $\begin{array}{l}24 \mathrm{~h} \text { agitation, } \\
\text { extraction fluid } \\
\text { no. } 1, \text { particle } \\
\text { size }<1 \mathrm{~cm}\end{array}$ & $\begin{array}{l}\mathrm{Cs} \\
\mathrm{Pb} \\
\mathrm{Cr} \\
\mathrm{Se} \\
\mathrm{Cd} \\
\mathrm{Zn} \\
\mathrm{Cu} \\
\mathrm{Co}\end{array}$ & $\begin{array}{l}<0.05 \\
0.005 \\
0.04 \\
0.01 \\
0.001 \\
0.05 \\
0.006 \\
0.001\end{array}$ & $\begin{array}{l}0.75 \\
0.60 \\
5.7 \\
0.11 \\
4.3\end{array}$ & $\begin{array}{l}\text { Vinokurov et al. } \\
\text { (2009) }\end{array}$ \\
\hline $\begin{array}{l}\text { Mayak supernatant } \\
\text { waste simulant, } \\
43 \text { wt.\% loading }\end{array}$ & $\begin{array}{l}296 \mathrm{~g} / \mathrm{L} \mathrm{Na}, 99 \mathrm{~g} / \mathrm{L} \mathrm{NO}_{3}^{-}, 38 \mathrm{~g} / \mathrm{L} \\
\mathrm{NO}_{2}^{-}, 91.5 \mathrm{~g} / \mathrm{L} \mathrm{OH}^{-}, \mathrm{Al}, \mathrm{Cl}^{-} \\
\mathrm{SO}_{4}^{-2}, \mathrm{Cr}, \mathrm{Cs}, \mathrm{Sr}, \mathrm{Tc}, \mathrm{I}, \mathrm{Se}\end{array}$ & $\begin{array}{l}24 \mathrm{~h} \text { agitation, } \\
\text { extraction fluid } \\
\text { no. } 1 \text {, particle } \\
\text { size }<1 \mathrm{~cm}\end{array}$ & $\begin{array}{l}\mathrm{Sr} \\
\mathrm{Cr} \\
\mathrm{Ni}\end{array}$ & $\begin{array}{l}0.07 \\
0.2 \\
0.5\end{array}$ & $\begin{array}{l}0.60 \\
11\end{array}$ & $\begin{array}{l}\text { Vinokurov et al. } \\
\text { (2009) }\end{array}$ \\
\hline
\end{tabular}


Table 7.2. TCLP Results on Ceramicrete Waste Forms Fabricated with WTP Secondary Waste Stream Simulants and Blank Samples (mg/l) (Singh et al. 2011)

\begin{tabular}{|c|c|c|c|c|c|c|c|c|}
\hline Composition & As & $\mathrm{Ba}$ & $\mathrm{Cd}$ & $\mathrm{Cr}$ & $\mathrm{Pb}$ & $\mathrm{Se}$ & $\mathrm{Ag}$ & $\mathrm{Hg}$ \\
\hline 45FA Blank & 0.183 & $<0.01$ & $<0.01$ & 0.375 & $<0.033$ & 0.172 & $<0.01$ & $<0.0007$ \\
\hline 45 CaSi Blank & $<0.05$ & 0.012 & $<0.01$ & 0.014 & $<0.033$ & 0.182 & $<0.01$ & $<0.0007$ \\
\hline 35FA+10Slag Blank & 0.074 & 0.011 & $<0.01$ & 0.011 & $<0.033$ & 0.268 & $<0.01$ & $<0.0007$ \\
\hline $45 \mathrm{FA}+20 \mathrm{WS}(\mathrm{B})$ & 0.15 & $<0.01$ & $<0.01$ & 0.013 & $<0.033$ & 0.303 & $<0.01$ & $<0.0007$ \\
\hline $45 \mathrm{FA}+15 \mathrm{WS}(\mathrm{B})$ & 0.13 & $<0.01$ & $<0.01$ & 0.015 & $<0.033$ & 0.129 & $<0.01$ & $<0.0007$ \\
\hline $45 \mathrm{CaSi}+20 \mathrm{WS}(\mathrm{B})$ & $<0.05$ & 0.31 & $<0.01$ & 0.016 & $<0.033$ & 0.227 & $<0.01$ & $<0.0007$ \\
\hline $45 \mathrm{CaSi}+15 \mathrm{WS}(\mathrm{B})$ & $<0.05$ & $<0.01$ & $<0.01$ & 0.019 & $<0.033$ & 0.182 & $<0.01$ & $<0.0007$ \\
\hline $35 \mathrm{FA}+10$ Slag+15WS(B) & 0.15 & $<0.01$ & $<0.01$ & 0.016 & $<0.033$ & 0.327 & $<0.01$ & $<0.0007$ \\
\hline 35FA+10Slag+10WS(B) & 0.14 & 0.01 & $<0.01$ & 0.019 & $<0.033$ & 0.397 & $<0.01$ & $<0.0007$ \\
\hline $45 \mathrm{FA}+20 \mathrm{WS}(\mathrm{C} 1)$ & 0.20 & $<0.01$ & $<0.01$ & 0.015 & $<0.033$ & 0.262 & $<0.01$ & $<0.0007$ \\
\hline $45 \mathrm{FA}+15 \mathrm{WS}(\mathrm{C} 1)$ & 0.12 & $<0.01$ & $<0.01$ & 0.018 & $<0.033$ & 0.457 & $<0.01$ & $<0.0007$ \\
\hline $45 \mathrm{CaSi}+20 \mathrm{WS}(\mathrm{C} 1)$ & $<0.05$ & $<0.01$ & $<0.01$ & $<0.01$ & $<0.033$ & 0.226 & $<0.01$ & $<0.0007$ \\
\hline $45 \mathrm{CaSi}+15 \mathrm{WS}(\mathrm{C} 1)$ & $<0.05$ & $<0.01$ & $<0.01$ & 0.011 & $<0.033$ & 0.208 & $<0.01$ & $<0.0007$ \\
\hline 35FA+10Slag+15WS(C1) & 0.076 & 0.012 & $<0.01$ & 0.020 & $<0.033$ & 0.260 & $<0.01$ & $<0.0007$ \\
\hline 35FA+10Slag+10WS(C1) & 0.060 & $<0.01$ & $<0.01$ & 0.014 & $<0.033$ & $<0.06$ & $<0.01$ & $<0.0007$ \\
\hline $45 \mathrm{FA}+20 \mathrm{WS}(\mathrm{C} 2)$ & 0.14 & 0.011 & $<0.01$ & 0.013 & $<0.033$ & 0.297 & $<0.01$ & $<0.0007$ \\
\hline $45 \mathrm{FA}+15 \mathrm{WS}(\mathrm{C} 2)$ & 0.15 & $<0.01$ & $<0.01$ & 0.015 & $<0.033$ & 0.173 & $<0.01$ & $<0.0007$ \\
\hline $45 \mathrm{CaSi}+20 \mathrm{WS}(\mathrm{C} 2)$ & 0.065 & $<0.01$ & $<0.01$ & $<0.01$ & $<0.033$ & 0.191 & $<0.01$ & $<0.0007$ \\
\hline $45 \mathrm{CaSi}+15 \mathrm{WS}(\mathrm{C} 2)$ & $<0.05$ & $<0.01$ & $<0.01$ & 0.012 & $<0.033$ & 0.085 & $<0.01$ & $<0.0007$ \\
\hline 35FA+10Slag+15WS(C2) & 0.31 & 0.019 & $<0.01$ & 0.028 & $<0.033$ & 0.398 & $<0.01$ & $<0.0007$ \\
\hline 35FA+10Slag+10WS(C2) & 0.25 & 0.013 & $<0.01$ & 0.016 & $<0.033$ & 0.283 & $<0.01$ & $<0.0007$ \\
\hline $45 \mathrm{FA}+20 \mathrm{WS}(\mathrm{M})$ & 0.096 & 0.011 & $<0.01$ & 0.017 & $<0.033$ & 0.267 & $<0.01$ & $<0.0007$ \\
\hline 45FA+15WS(M) & 0.182 & $<0.01$ & $<0.01$ & 0.011 & $<0.033$ & 0.257 & $<0.01$ & $<0.0007$ \\
\hline 45CaSi+20WS(M) & $<0.05$ & $<0.01$ & $<0.01$ & 0.0144 & $<0.033$ & 0.219 & $<0.01$ & $<0.0007$ \\
\hline $45 \mathrm{CaSi}+15 \mathrm{WS}(\mathrm{M})$ & $<0.05$ & $<0.01$ & $<0.01$ & $<0.01$ & $<0.033$ & $<0.06$ & $<0.01$ & $<0.0007$ \\
\hline $35 \mathrm{FA}+10$ Slag $+10 \mathrm{WS}(\mathrm{M})$ & $<0.05$ & $<0.01$ & $<0.01$ & 0.011 & $<0.033$ & $<0.06$ & $<0.01$ & $<0.0007$ \\
\hline $35 \mathrm{FA}+10$ Slag $+15 \mathrm{WS}(\mathrm{M})$ & 0.072 & $<0.01$ & $<0.01$ & 0.013 & $<0.033$ & 0.138 & $<0.01$ & $<0.0007$ \\
\hline $\begin{array}{l}\text { Universal Treatment } \\
\text { Standard } \\
\end{array}$ & 5 & 21 & 0.11 & 0.6 & 0.75 & 5.7 & 0.14 & 0.025 \\
\hline
\end{tabular}

Table 7.3. Radiolytic Hydrogen Generation in Ceramicrete Containing Various Concentrations of Pu (Wagh et al. 1999b)

\begin{tabular}{lcc}
\hline \multicolumn{1}{c}{ Sample } & Wt. $\% \mathrm{Pu}$ & G Value (molecular $\left.\mathrm{H}_{2} / 100 \mathrm{eV}\right)$ \\
\hline CBPC containing U-Pu oxide mixture & 5.245 & 0.13 \\
CBPC containing TRU combustible residue & 7.87 & 0.10 \\
CBPC containing TRU combustible residue & 5.00 & 0.23 \\
$\begin{array}{l}\text { CBPC containing TRU combustible residue and Bakelite } \\
\text { compound }\end{array}$ & 31.8 & 31.8 \\
\hline
\end{tabular}




\subsection{Pyrophoricity}

Pyrophoricity is a property of metals and oxides of lower oxidation states, including radioactive elements, in which they spontaneously ignite during or after stabilization. An example of a pyrophoric component is $\mathrm{Pu}_{2} \mathrm{O}_{3}$. Oxidation to $\mathrm{PuO}_{2}$ renders this element nonpyrophoric. It is not expected that any pyrophoric components of concern will occur at levels of concern in the secondary waste stream.

\subsection{Compressive Strength}

Compressive strength results for Ceramicrete waste forms fabricated with wastes relevant to secondary waste streams are shown in Table 7.4. The IDF WAC requirement for compressive strength is that the compressive strength of the waste form shall be at least $3.54 \times 10^{6} \mathrm{~Pa}(500 \mathrm{psi})$ when tested in accordance with ASTM C39/C39M.

These compressive strength results include data compiled for waste forms made with surrogate salt waste (Wagh et al. 2001); Hanford Site tank supernatant waste simulant (Wagh et al. 2003); ${ }^{99} \mathrm{Tc}$ eluent waste simulant (Singh et al. 2006); WTP HSW simulant and INTEC SBW simulants (Russell et al. 2006); Hanford Site tank supernatant waste and Mayak supernatant waste simulant (Vinokurov et al. 2009); and metal nitrate solutions (Buj et al. 2009). In all cases, the measured compressive strength exceeded the $3.54 \times 10^{6} \mathrm{~Pa}(500 \mathrm{psi})$ requirement.

Compressive strength data for Ceramicrete waste forms fabricated with simulated WTP secondary waste streams that were cured for periods of 16 to 96 days are shown in Tables 7.5-7.8 (Singh et al. 2011). The waste form compositions, simulated WTP secondary waste stream compositions, and waste loadings are available in (Singh et al. 2011). The only Ceramicrete waste form composition that did not meet the minimum compressive strength requirement for IDF waste acceptance (3.54E6 Pa, 500 psi) was $25 \mathrm{FA}+25 \mathrm{~W}+1 \mathrm{~B}$.A fabricated with the mixed simulant. Compressive strengths of waste forms fabricated with baseline simulants at waste loadings of up to $20 \mathrm{wt} . \%$ had compressive strengths that were greater than 2500 psi. Compressive strengths generally increased with increasing cure times. Significantly lower compressive strengths were observed for waste forms containing $25 \mathrm{wt} . \%$ filler (fly ash or $\mathrm{CaSiO}_{3}$ ) relative to $45 \mathrm{wt} . \%$ filler. Waste forms fabricated with cluster 1, cluster 2 , and mixed wastes exhibited trends that were simular to those for the baseline wasteforms; however, the mixed waste forms exhibited a somewhat higher degree of scatter than the other wasteforms. 
Table 7.4. Compressive Strength Results for Ceramicrete Waste Forms

\begin{tabular}{|c|c|c|c|c|}
\hline Waste Type/Loading & Actual Waste/Simulant/Spikes & Preparation & Compressive Strength & Reference \\
\hline $\begin{array}{l}\text { Surrogate salt waste }\left(\mathrm{NaNO}_{3} \text { and }\right. \\
\mathrm{NaCl}), 58 \text { and } 70 \text { wt. } \%\end{array}$ & $\begin{array}{l}\text { Both } \mathrm{NO}_{3}{ }^{-} \text {and } \mathrm{Cl}^{-} \text {wastes contained } \mathrm{Fe}_{2} \mathrm{O}_{3} \text {, } \\
\mathrm{Al}(\mathrm{OH})_{3}, \mathrm{Na}_{3} \mathrm{PO}_{4}, \mathrm{Ca}_{2} \mathrm{SiO}_{4} \text {, and water as major } \\
\text { components, } \mathrm{NaCl}, \mathrm{CaSO}_{4} \text {, and } \mathrm{NaNO}_{3} \text { as } \\
\text { salts; and } \mathrm{Pb} \mathrm{Cr}, \mathrm{Hg}, \mathrm{Cd} \text {, and } \mathrm{Ni} \text { (up to } \\
800-900 \text { ppm) as heavy metals in each of the } \\
\text { contaminant oxides, trichloroethylene }\end{array}$ & & $\begin{array}{l}1900 \text { psi }(13 \mathrm{MPa}) \\
\mathrm{NO}_{3} \text { waste } \\
1400 \text { psi }(9.7 \mathrm{MPa}) \mathrm{Cl} \\
\text { waste }\end{array}$ & Wagh et al. (2001) \\
\hline $\begin{array}{l}\text { Hanford tank supernatant waste } \\
\text { simulant, } 39.8 \text { wt. } \% \text { loading }\end{array}$ & $\begin{array}{l}17 \text { wt.\% Na, } 11.5 \text { wt.\% } \mathrm{NO}_{3}^{-}, \mathrm{pH}=13.7, \mathrm{Cs}, \\
\mathrm{Ba}, \mathrm{Re}, \mathrm{Cd}(2.3 \mathrm{ppm}), \mathrm{Cr}(938 \mathrm{ppm}), \mathrm{Ag} \\
\text { (11.5 ppm), } \mathrm{Pb}(37 \mathrm{ppm}) \text {, and } \mathrm{Zn}(7.04 \mathrm{ppm})\end{array}$ & & $12-24 \mathrm{MPa}$ & Wagh et al. (2003) \\
\hline $\begin{array}{l}{ }^{99} \mathrm{Tc} \text { eluent waste simulant with } \\
\mathrm{SnCl}_{2} \text { stabilization, } 36 \mathrm{wt} . \% \\
\text { loading }\end{array}$ & $\begin{array}{l}1 \mathrm{M} \mathrm{NaOH}, 1 \mathrm{M} \text { ethylenediamine, } 0.005 \mathrm{M} \\
\mathrm{Sn}(\mathrm{II}), 20-150 \mathrm{ppm} \mathrm{Tc}\end{array}$ & & $30 \pm 7 \mathrm{MPa}$ & Singh et al. (2006) \\
\hline WTP HSW simulant, 25.8 wt.\% & $\begin{array}{l}\mathrm{Na}(45.2 \mathrm{~g} / \mathrm{L}), \mathrm{CO}_{3}^{-2}(60 \mathrm{~g} / \mathrm{L}), \mathrm{NO}_{3}^{-}(1.12 \mathrm{~g} / \mathrm{L}) \\
\mathrm{OH}^{-}(1.6 \mathrm{~g} / \mathrm{L}), \mathrm{TOC}(13.9 \mathrm{~g} / \mathrm{L}), \mathrm{Al}(0.32 \mathrm{~g} / \mathrm{L}) \\
\mathrm{Cr}, \mathrm{Ag}, \mathrm{Cd}, \mathrm{Re}, \mathrm{I}, \mathrm{Hg}, \mathrm{Pb}\end{array}$ & $\begin{array}{l}\text { 21-day as-prepared (ANL) } \\
\text { freeze-thaw cycling (ANL) } \\
\text { no } \mathrm{rad}(\mathrm{PNNL}) \\
10^{8} \mathrm{rad}(\mathrm{PNNL})\end{array}$ & $\begin{array}{l}4076 \mathrm{psi}(28.1 \mathrm{MPa}) \\
2057 \mathrm{psi}(14.2 \mathrm{MPa}) \\
4870 \mathrm{psi}(33.6 \mathrm{MPa}) \\
5020 \mathrm{psi}(34.6 \mathrm{MPa})\end{array}$ & Russell et al. (2006) \\
\hline INTEC SBW simulant, 47.4 wt.\% & $\begin{array}{l}\mathrm{Na}(43.2 \mathrm{~g} / \mathrm{L}), \mathrm{NO}_{3}^{-}(269 \mathrm{~g} / \mathrm{L}), \mathrm{Al}(17.8 \mathrm{~g} / \mathrm{L}) \\
\mathrm{SO}_{4}(5.15 \mathrm{~g} / \mathrm{L}), \mathrm{Ca}(1.46 \mathrm{~g} / \mathrm{L}), \mathrm{K}(6.8 \mathrm{~g} / \mathrm{L}), \mathrm{Cl}^{-} \\
(1.15 \mathrm{~g} / \mathrm{L}), \mathrm{F}^{-}(0.83 \mathrm{~g} / \mathrm{L}), \mathrm{B}, \mathrm{Mg}, \mathrm{Cr}, \mathrm{Mn}, \mathrm{Fe} \\
\mathrm{Cd}, \mathrm{Cs}, \mathrm{Ce}, \mathrm{Hg}, \mathrm{Pb}, \mathrm{Re}, \mathrm{I}\end{array}$ & $\begin{array}{l}\text { 21-day as-prepared (ANL) } \\
\text { freeze-thaw cycling (ANL) } \\
\text { no rad (PNNL) } \\
10^{8} \mathrm{rad}(\mathrm{PNNL})\end{array}$ & $\begin{array}{l}4603 \mathrm{psi}(31.7 \mathrm{MPa}) \\
2230 \mathrm{psi}(15.4 \mathrm{MPa}) \\
5160 \mathrm{psi}(35.6 \mathrm{MPa}) \\
4910 \mathrm{psi}(33.8 \mathrm{MPa})\end{array}$ & Russell et al. (2006) \\
\hline $\begin{array}{l}\text { Hanford tank supernatant waste } \\
\text { simulant, } 35 \mathrm{wt} . \% \text { loading }\end{array}$ & $\begin{array}{l}256 \mathrm{~g} / \mathrm{L} \mathrm{Na}, 168 \mathrm{~g} / \mathrm{L} \mathrm{NO}_{3}^{-}, 113 \mathrm{~g} / \mathrm{L} \mathrm{NO}_{2}^{-} \\
83.7 \mathrm{~g} / \mathrm{L} \mathrm{OH}^{-}, \mathrm{CO}_{3}, \mathrm{Al}, \mathrm{Cl}, \mathrm{Cs}, \mathrm{Sr}, \mathrm{SO}_{4}, \mathrm{Cr}, \mathrm{Pb} \\
\mathrm{Cd}, \mathrm{K}, \mathrm{Am}, \mathrm{Ce}, \mathrm{Pu}, \mathrm{Np}, \mathrm{Am}, \mathrm{Sr}, \mathrm{Cs}, \mathrm{Tc}, \mathrm{I}, \mathrm{Se}\end{array}$ & $\begin{array}{l}\text { No irradiation and } 2.8 \times 10^{8} \mathrm{rad} \\
\left({ }^{60} \mathrm{Co}\right)\end{array}$ & $25-55 \mathrm{MPa}$ & Vinokurov et al. (2009) \\
\hline $\begin{array}{l}\text { Mayak supernatant waste } \\
\text { simulant, } 43 \text { wt.\% loading }\end{array}$ & $\begin{array}{l}296 \mathrm{~g} / \mathrm{L} \mathrm{Na}, 99 \mathrm{~g} / \mathrm{L} \mathrm{NO}_{3}^{-}, 38 \mathrm{~g} / \mathrm{L} \mathrm{NO}_{2}^{-}, 91.5 \\
\mathrm{~g} / \mathrm{L} \mathrm{OH}, \mathrm{Al}, \mathrm{Cl}^{-}, \mathrm{SO}_{4}, \mathrm{Cr}, \mathrm{Cs}, \mathrm{Sr}, \mathrm{Tc}, \mathrm{I}, \mathrm{Se}\end{array}$ & $\begin{array}{l}\text { No irradiation and } 2.8 \times 10^{8} \mathrm{rad} \\
\left({ }^{60} \mathrm{Co}\right)\end{array}$ & $>20 \mathrm{MPa}$ & Vinokurov et al. (2009) \\
\hline Metal nitrate solutions & $\mathrm{Cd}, \mathrm{Cr}(\mathrm{III}), \mathrm{Cu}, \mathrm{Ni}, \mathrm{Pb}$, or $\mathrm{Zn}$ at $25 \mathrm{~g} / \mathrm{dm}^{3}$ & $\begin{array}{l}\text { Water-to-solid (W/S) ratio of } 0.3 \\
\text { to } 0.6 \mathrm{dm}^{3} / \mathrm{kg}\end{array}$ & $\begin{array}{l}>3.45 \mathrm{MPa} \text { for all } \\
\text { metals at W/S of } 0.3 \\
\text { and } 0.4 \mathrm{dm}^{3} / \mathrm{kg}\end{array}$ & Buj et al. (2009) \\
\hline
\end{tabular}


Table 7.5. Compressive Strength (psi) for Ceramicrete Waste Forms Fabricated with WTP Simulated Secondary Waste (Baseline) (Singh et al. 2011)

\begin{tabular}{lcc|cc|cr}
\hline \multirow{2}{*}{$\begin{array}{c}\text { Sample } \\
\text { Composition }\end{array}$} & \multicolumn{2}{c|}{$16-20$ days } & \multicolumn{2}{c|}{ 30-35 days } & \multicolumn{2}{c}{60 days } \\
\cline { 2 - 6 } & $\begin{array}{c}\text { Average } \\
\text { Compressive } \\
\text { Strength (psi) }\end{array}$ & STDEV & $\begin{array}{c}\text { Average } \\
\text { Compressive } \\
\text { Strength (psi) }\end{array}$ & STDEV & \multicolumn{2}{c}{$\begin{array}{c}\text { Average } \\
\text { Compressive } \\
\text { Strength (psi) }\end{array}$} \\
45FA+20W & 2698 & 1032 & 3203 & 691 & 4260 & 542 \\
45FA+15W & 2595 & 560 & 3755 & 1753 & 5583 & 347 \\
45FA+5W & 3239 & 175 & 4332 & 132 & 4568 & 857 \\
45FABlank & 4479 & 616 & 4150 & 602 & 5555 & 1034 \\
25FA+25W & 3680 & 1584 & 4582 & 1546 & 4189 & 376 \\
25FABlank & 1113 & 415 & 1321 & 398 & 1582 & 292 \\
25FA+25W+1B.A. & 1317 & 420 & 2351 & 438 & 1236 & 28 \\
\hline 45CaSi+20W & 1215 & 134 & 1358 & 42 & 1819 & 34 \\
\hline 45CaSi+15W & 4794 & 126 & 6196 & 1342 & 5901 & 192 \\
45CaSiBlank & 3968 & 300 & 5473 & 811 & 4994 & 92 \\
25CaSi+25W & 4423 & 651 & 5760 & 1029 & 5037 & 197 \\
25CaSiBlank & 2768 & 553 & 3152 & 968 & 2525 & 547 \\
\hline 35FA+10Slg+10W & 3044 & 760 & 4454 & 1077 & 3218 & 442 \\
35FA+10SlgBlank & 3623 & 703 & 4834 & 1035 & 3727 & 1315 \\
35FA+10Slg+15W & 5378 & 266 & 7376 & 0 & 5682 & 2162 \\
\hline
\end{tabular}

Table 7.6. Compressive Strength (psi) for Ceramicrete Waste Forms Fabricated with WTP Simulated Secondary Waste (Cluster 1) (Singh et al. 2011)

\begin{tabular}{lcc|cc|cc}
\hline & \multicolumn{2}{c|}{$16-19$ days } & \multicolumn{2}{c|}{$30-39$ days } & \multicolumn{2}{c}{$90-96$ days } \\
\cline { 2 - 7 } & $\begin{array}{c}\text { Average } \\
\text { Compressive } \\
\text { Strength (psi) }\end{array}$ & STDEV & $\begin{array}{c}\text { Average } \\
\text { Compressive } \\
\text { Strength (psi) }\end{array}$ & STDEV & $\begin{array}{c}\text { Average } \\
\text { Compressive } \\
\text { Strength (psi) }\end{array}$ & STDEV \\
\hline 45FA+20W & 2275 & 485 & 4259 & 639 & 3799 & 1900.41 \\
45FA+15W & 3193 & 562 & 6477 & 0 & 3910 & 2201 \\
45FA+10W & 3960 & 1230 & 4820 & 687 & 4837.65 & 2366 \\
45FA+5W & 3075 & 733 & 4018 & 1395 & 3765 & 1297 \\
45FABlank & 3680 & 1584 & 4582 & 1546 & NT & NT \\
25FA+25W & 1631 & 180 & 1376 & 571 & 1533 & 465 \\
25FABlank & 1317 & 420 & 2351 & 439 & NT & NT \\
25FA+25W+1B.A. & 2242 & 702 & 2181 & 712 & 2122 & 171 \\
\hline 45CaSi+20W & 4712 & 615 & 3632 & 154 & 4391 & 954 \\
45CaSi+15W & 4381 & 985 & 4932 & 736 & 4672 & 790 \\
45CaSiBlank & 4423 & 651 & 5760 & 1029 & NT & NT \\
25CaSi+25W & 2873 & 268 & 3540 & 1477 & 3548 & 90 \\
25CaSiBlank & 3044 & 760 & 4454 & 1076 & NT & NT \\
\hline 35FA+10Slg+10W & 4806 & 585 & 5005 & 1146 & 4959 & 1131 \\
\hline 35FA+10SlgBlank & 5378 & 266 & 7376 & 0 & NT & NT \\
35FA+10Slg+15W & 2760 & 360 & 3503 & 791 & 2378 & 836 \\
\hline
\end{tabular}


Table 7.7. Compressive Strength (psi) for Ceramicrete Waste Forms Fabricated with WTP Simulated Secondary Waste (Cluster 2) (Singh et al. 2011)

\begin{tabular}{lcc}
\hline & \multicolumn{2}{c}{$21-30$ days } \\
\cline { 2 - 3 } \multicolumn{1}{c}{ Sample Composition } & $\begin{array}{c}\text { Average } \\
\text { Compressive } \\
\text { Strength (psi) }\end{array}$ & STDEV \\
\hline 45FA+20W & 4005 & 167 \\
45FA+15W & 4483 & 569 \\
45FA+10W & 3269 & 368 \\
45FA+5W & 2186 & 579 \\
45FABlank & 4582 & 1546 \\
25FA+25W & 1370 & 431 \\
25FABlank & 2351 & 439 \\
25FA+25W+1B.Acid & 840 & 224 \\
\hline 45CaSi+20W & 4950 & 355 \\
45CaSi+15W & 4230 & 868 \\
45CaSiBlank & 5760 & 1029 \\
25CaSi+25W & 2618 & 115 \\
25CaSiBlank & 4454 & 1076 \\
\hline 35FA+10Slg+10W & 4039 & 304 \\
35FA+10SlgBlank & 7376 & 0 \\
35FA+10Slg+15W & 2201 & 426 \\
\hline
\end{tabular}

Table 7.8. Compressive Strength (psi) for Ceramicrete Waste Forms Fabricated with WTP Simulated Secondary Waste (Mixed) (Singh et al. 2011)

\begin{tabular}{lcc|cc}
\hline & \multicolumn{2}{c|}{$16-20$ days } & \multicolumn{2}{c}{$30-40$ days } \\
\cline { 2 - 5 } Sample Composition & $\begin{array}{c}\text { Average } \\
\text { Compressive } \\
\text { Strength (psi) }\end{array}$ & STDEV & $\begin{array}{c}\text { Average } \\
\text { Compressive } \\
\text { Strength (psi) }\end{array}$ & STDEV \\
\hline 45FA+20W & 2403 & 720.64 & 4561 & 1907 \\
45FA+15W & 3577 & 1622 & 3892 & 1873 \\
45FA+10W & 3130 & 415 & 4299 & 1587 \\
45FA+5W & 3101 & 520 & 2626 & 756 \\
45FABlank & 3680 & 1584 & 4582 & 1547 \\
25FA+25W & 1874 & 249 & - & - \\
25FABlank & 1316 & 419 & - & - \\
25FA+25W+1B.Acid & 147 & 66 & - & - \\
\hline 45CaSi+20W & 3296 & 573 & - & - \\
45CaSi+15W & 4469 & 602 & - & - \\
45CaSiBlank & 4422 & 651 & - & - \\
25CaSi+25W & 2792 & 170 & - & - \\
25CaSiBlank & 3043 & 760 & - & - \\
\hline 35FA+10Slg+10W & 2631 & 1712 & - & - \\
\hline 35FA+10SlgBlank & 5378 & 266 & - & - \\
35FA+10Slg+15W & 1875 & 997 & & - \\
\hline
\end{tabular}


Compressive strength data for Ceramicrete waste forms fabricated with simulated WTP secondary waste streams that were immersed in water for periods of 16 to 90 days are shown in Tables 7.9-7.12 (Singh et al. 2011). For the un-immersed waste forms, the only waste form composition that did not meet the minimum compressive strength requirement for IDF waste acceptance (3.54E6 Pa, 500 psi) was $25 \mathrm{FA}+25 \mathrm{~W}+1 \mathrm{~B}$.A fabricated with the mixed simulant and cluster 2 (30 day immersion only, 60 day and 90 day immersion tests were $>500 \mathrm{psi}$ ). Compressive strengths of water immersed samples were similar or even increased with immersion as compared to the as-fabricated samples for the same filler and waste loading for baseline, cluster 1 and mixed wastes. Cluster 2 waste forms exhibited a drop in strength with immersion time compared to the as-fabricated samples. Similar to the un-immersed samples, wastes forms with $25 \mathrm{wt} . \%$ filler and $25 \mathrm{wt} . \%$ waste loading exhibited low compressive strength.

Table 7.9. Compressive Strength (psi) for Ceramicrete Waste Forms Fabricated with WTP Simulated Secondary Waste (Baseline) Immersed in Water (Singh et al. 2011)

\begin{tabular}{|c|c|c|c|c|c|c|}
\hline \multirow[b]{2}{*}{ Sample Composition } & \multicolumn{2}{|c|}{ (30 days $\mathrm{H}_{2} \mathrm{O}$ Immersion) } & \multicolumn{2}{|c|}{ (60 days $\mathrm{H}_{2} \mathrm{O}$ Immersion) } & \multicolumn{2}{|c|}{ (90 days $\mathrm{H}_{2} \mathrm{O}$ Immersion) } \\
\hline & $\begin{array}{c}\text { Average } \\
\text { Compressive } \\
\text { Strength (psi) }\end{array}$ & STDEV & $\begin{array}{c}\text { Average } \\
\text { Compressive } \\
\text { Strength (psi) }\end{array}$ & STDEV & $\begin{array}{c}\text { Average } \\
\text { Compressive } \\
\text { Strength (psi) }\end{array}$ & STDEV \\
\hline $45 \mathrm{FA}+20 \mathrm{~W}$ & 3095 & 652 & 3354 & 376 & 3948 & 1645 \\
\hline $45 \mathrm{FA}+15 \mathrm{~W}$ & 2974 & 51 & 3330 & 1238.92 & 3205 & 1868 \\
\hline $45 \mathrm{FA}+10 \mathrm{~W}$ & 4102 & 666 & 4210 & 309 & 4173 & 663 \\
\hline $45 \mathrm{FA}+5 \mathrm{~W}$ & 3049 & 676 & 2802 & 792 & 2944 & 702 \\
\hline 45FABlank & 3582 & 326 & 3088 & 839 & 3083 & 911 \\
\hline $25 \mathrm{FA}+25 \mathrm{~W}$ & 1138 & 115 & 941 & 191 & 1325 & 308 \\
\hline 25FABlank & 900 & 160 & 1201 & 411 & 1401 & 85 \\
\hline $25 \mathrm{FA}+25 \mathrm{~W}+1 \mathrm{~B} . \mathrm{A}$. & 748 & 180 & 1431 & 276 & NT & NT \\
\hline $45 \mathrm{CaSi}+20 \mathrm{~W}$ & 4299 & 578 & 3000 & 464 & 5051 & 537 \\
\hline $45 \mathrm{CaSi}+15 \mathrm{~W}$ & 3943 & 333 & 4102 & 1110 & 4337 & 276 \\
\hline 45CaSiBlank & 3743 & 410 & 4412 & 611 & 4846 & 1124 \\
\hline $25 \mathrm{CaSi}+25 \mathrm{~W}$ & 3434 & 170 & 3104 & 849 & 2995 & 1220 \\
\hline 25CaSiBlank & 2977 & 714 & 3709 & 877 & 2187 & 681 \\
\hline $35 \mathrm{FA}+10 \mathrm{Slg}+10 \mathrm{~W}$ & 3784 & 1758 & 4531 & 927 & NT & NT \\
\hline $35 \mathrm{FA}+10$ SlgBlank & 2878 & 483 & 6117 & 853 & 4742 & 700 \\
\hline $35 \mathrm{FA}+10 \mathrm{Slg}+15 \mathrm{~W}$ & 3393 & 87 & 2946 & 69 & 3084 & 1926 \\
\hline
\end{tabular}


Table 7.10. Compressive Strength (psi) for Ceramicrete Waste Forms Fabricated with WTP Simulated Secondary Waste (Cluster 1) Immersed in Water (Singh et al. 2011)

\begin{tabular}{|c|c|c|c|c|c|c|}
\hline \multirow[b]{2}{*}{ Sample Composition } & \multicolumn{2}{|c|}{ (30 days $\mathrm{H}_{2} \mathrm{O}$ Immersion) } & \multicolumn{2}{|c|}{ (60 days $\mathrm{H}_{2} \mathrm{O}$ Immersion) } & \multicolumn{2}{|c|}{ (90 days $\mathrm{H}_{2} \mathrm{O}$ Immersion) } \\
\hline & $\begin{array}{c}\text { Average } \\
\text { Compressive } \\
\text { Strength (psi) }\end{array}$ & STDEV & $\begin{array}{c}\text { Average } \\
\text { Compressive } \\
\text { Strength (psi) }\end{array}$ & STDEV & $\begin{array}{c}\text { Average } \\
\text { Compressive } \\
\text { Strength (psi) }\end{array}$ & STDEV \\
\hline $45 \mathrm{FA}+20 \mathrm{~W}$ & 3167 & 924 & 2501 & 236 & 3307 & 465 \\
\hline $45 \mathrm{FA}+15 \mathrm{~W}$ & 3840 & 1700 & 3788 & 838 & 3228 & 625 \\
\hline $45 \mathrm{FA}+10 \mathrm{~W}$ & 3244 & 383 & 5349 & 642 & 4997 & 2114 \\
\hline $45 \mathrm{FA}+5 \mathrm{~W}$ & 2500 & 3 & 3524 & 1432 & 2974 & 843 \\
\hline 45FABlank & 3582 & 326 & 3088 & 839 & 3083 & 911 \\
\hline $25 \mathrm{FA}+25 \mathrm{~W}$ & 825 & 1 & 1093 & 210 & 603 & 293 \\
\hline 25FABlank & 900 & 160 & 1201 & 411 & 1401 & 85 \\
\hline $25 \mathrm{FA}+25 \mathrm{~W}+1 \mathrm{~B} . \mathrm{A}$. & 1465 & 263 & 2317 & 164 & NT & NT \\
\hline $45 \mathrm{CaSi}+20 \mathrm{~W}$ & 3625 & 1656 & 2992 & 209 & 4371 & 1066 \\
\hline $45 \mathrm{CaSi}+15 \mathrm{~W}$ & 2925 & 264 & 3874 & 754 & 3220 & 648 \\
\hline 45CaSiBlank & 3743 & 410 & 4412 & 611 & 4845 & 1124 \\
\hline $25 \mathrm{CaSi}+25 \mathrm{~W}$ & 3170 & 918 & 2815 & 679 & 2550 & 294 \\
\hline 25CaSiBlank & 2977 & 714 & 3709 & 877 & 2187 & 681 \\
\hline $35 \mathrm{FA}+10 \mathrm{Slg}+10 \mathrm{~W}$ & 3617 & 148 & 6734 & 1226 & 5597 & 2185 \\
\hline 35FA+10SlgBlank & 2878 & 483 & 6117 & 853 & 4742 & 700 \\
\hline $35 \mathrm{FA}+10 \mathrm{Slg}+15 \mathrm{~W}$ & 3222 & 886 & 1808 & 1359 & 3523 & 777 \\
\hline
\end{tabular}

Table 7.11. Compressive Strength (psi) for Ceramicrete Waste Forms Fabricated with WTP Simulated Secondary Waste (Cluster 2) Immersed in Water (Singh et al. 2011)

\begin{tabular}{|c|c|c|c|c|c|c|}
\hline \multirow[b]{2}{*}{ Sample Composition } & \multicolumn{2}{|c|}{ (30 days $\mathrm{H}_{2} \mathrm{O}$ Immersion) } & \multicolumn{2}{|c|}{ (60 days $\mathrm{H}_{2} \mathrm{O}$ Immersion $)$} & \multicolumn{2}{|c|}{ (90 days $\mathrm{H}_{2} \mathrm{O}$ Immersion) } \\
\hline & $\begin{array}{c}\text { Average } \\
\text { Compressive } \\
\text { Strength (psi) }\end{array}$ & STDEV & $\begin{array}{c}\text { Average } \\
\text { Compressive } \\
\text { Strength (psi) }\end{array}$ & STDEV & $\begin{array}{c}\text { Average } \\
\text { Compressive } \\
\text { Strength (psi) }\end{array}$ & STDEV \\
\hline $45 \mathrm{FA}+20 \mathrm{~W}$ & 2441 & 320 & 1612 & 299.27 & 2297 & 257 \\
\hline $45 \mathrm{FA}+15 \mathrm{~W}$ & 3467 & 559 & 2695 & 126 & 2759 & 537 \\
\hline $45 \mathrm{FA}+10 \mathrm{~W}$ & 1519 & 312 & 2124 & 35 & 2515 & 570 \\
\hline $45 \mathrm{FA}+5 \mathrm{~W}$ & 2377 & 517 & 2272 & 264 & 2203 & 281 \\
\hline 45FABlank & 3582 & 326 & 3088 & 839 & 3083 & 911 \\
\hline $25 \mathrm{FA}+25 \mathrm{~W}$ & 1180 & 120 & 1207 & 167 & 1178 & 97 \\
\hline 25FABlank & 900 & 160 & 1201 & 411 & 1401 & 85 \\
\hline 25FA+25W+1B.Acid & 456 & 155 & 615 & 204 & 841 & 223 \\
\hline $45 \mathrm{CaSi}+20 \mathrm{~W}$ & 3868 & 290 & 3807 & 202 & 3234 & 643 \\
\hline $45 \mathrm{CaSi}+15 \mathrm{~W}$ & 3594 & 489 & 4147 & 1098 & 4053 & 324 \\
\hline 45CaSiBlank & 3743 & 410 & 4412 & 611 & 4845 & 1124 \\
\hline $25 \mathrm{CaSi}+25 \mathrm{~W}$ & 2400 & 891 & 1927 & 224 & 2402 & 800 \\
\hline 25CaSiBlank & 2977 & 714 & 4412 & 611 & 2187 & 681 \\
\hline $35 \mathrm{FA}+10 \mathrm{Slg}+10 \mathrm{~W}$ & 2364 & 430 & 1973 & 783 & 2178 & 238 \\
\hline 35FA+10SlgBlank & 2878 & 483 & 6117 & 853 & 4742 & 700 \\
\hline $35 \mathrm{FA}+10 \mathrm{Slg}+15 \mathrm{~W}$ & 1413 & 420 & 1477 & 403 & 1537 & 475 \\
\hline
\end{tabular}


Table 7.12. Compressive Strength (psi) for Ceramicrete Waste Forms Fabricated with WTP Simulated Secondary Waste (Mixed) Immersed in Water (Singh et al. 2011)

\begin{tabular}{|c|c|c|c|c|c|c|}
\hline \multirow[b]{2}{*}{ Sample Composition } & \multicolumn{2}{|c|}{ (30 days $\mathrm{H}_{2} \mathrm{O}$ Immersion) } & \multicolumn{2}{|c|}{ (60 days $\mathrm{H}_{2} \mathrm{O}$ Immersion) } & \multicolumn{2}{|c|}{ (90 days $\mathrm{H}_{2} \mathrm{O}$ Immersion } \\
\hline & $\begin{array}{c}\text { Average } \\
\text { Compressive } \\
\text { Strength (psi) } \\
\end{array}$ & STDEV & $\begin{array}{c}\text { Average } \\
\text { Compressive } \\
\text { Strength (psi) } \\
\end{array}$ & STDEV & $\begin{array}{c}\text { Average } \\
\text { Compressive } \\
\text { Strength (psi) } \\
\end{array}$ & STDEV \\
\hline $45 \mathrm{FA}+20 \mathrm{~W}$ & 2598 & 586 & 3078 & 586 & 3174 & 1204 \\
\hline $45 \mathrm{FA}+15 \mathrm{~W}$ & 2431 & 1590 & 3353 & 1590 & 2586 & 1100 \\
\hline $45 \mathrm{FA}+10 \mathrm{~W}$ & 4030 & 1073 & 4625 & 1073 & 3266 & 484 \\
\hline $45 \mathrm{FA}+5 \mathrm{~W}$ & 2879 & 797 & 2740 & 797 & 3966 & 1148 \\
\hline 45FABlank & 3582 & 326 & 3088 & 839 & 3083 & 911 \\
\hline $25 \mathrm{FA}+25 \mathrm{~W}$ & 1976 & 376 & 4155 & 597 & 2472 & 548 \\
\hline 25FABlank & 900 & 160 & 1201 & 411 & 1401 & 85 \\
\hline $25 \mathrm{FA}+25 \mathrm{~W}+1 \mathrm{~B}$. Acid & 19 & 33 & 242 & 113 & 196 & 63 \\
\hline $45 \mathrm{CaSi}+20 \mathrm{~W}$ & 4062 & 7545 & 3912 & 782 & 3173 & 184 \\
\hline $45 \mathrm{CaSi}+15 \mathrm{~W}$ & 3672 & 560 & 3551 & 923 & 3334 & 1443 \\
\hline 45CaSiBlank & 3743 & 410 & 4412 & 611 & 4845 & 1124 \\
\hline $25 \mathrm{CaSi}+25 \mathrm{~W}$ & 1909 & 1110 & 1940 & 6 & 1774 & 1043 \\
\hline 25CaSiBlank & 2977 & 714 & 3709 & 877 & 2188 & 681 \\
\hline $35 \mathrm{FA}+10 \mathrm{Slg}+10 \mathrm{~W}$ & 3315 & 153 & 1950 & 891 & 2672 & 648 \\
\hline $35 \mathrm{FA}+10 \mathrm{SlgBlank}$ & 2878 & 483 & 6117 & 853 & 4742 & 700 \\
\hline $35 \mathrm{FA}+10 \mathrm{Slg}+15 \mathrm{~W}$ & 1896 & 903 & 2598 & 1082 & 1187 & 225 \\
\hline
\end{tabular}

\subsection{Leachability Index}

Leachability data for Ceramicrete waste forms fabricated with wastes relevant to secondary waste streams are shown in Table 7.13. The leachability data are presented in terms of leachability index, diffusivity (ANSI/ANS-16.1, ANS [1986]), and leaching rate (PCT, ASTM [1997]).

The leachability index (LI) is defined as follows:

$$
\mathrm{LI}=-\log (\mathrm{D})
$$

where $\mathrm{D}$ is the effective diffusivity $\left(\mathrm{cm}^{2} / \mathrm{s}\right)$.

Leachability index and diffusivity data available in Table 7.13 include results for waste forms made with surrogate salt waste (Wagh et al. 2001) and ${ }^{99}$ Tc eluent waste simulant (Singh et al. 2006). Note that the ${ }^{99} \mathrm{Tc}$ eluent waste simulant samples were prepared in an anoxic (nitrogen) atmosphere and the leach tests were also conducted in an anoxic (nitrogen) atmosphere. Additional leachability index data in Table 7.5 include results for waste forms made with WTP HSW simulant and INTEC SBW simulants (Russell et al. 2006), and Hanford Site tank supernatant waste and Mayak supernatant waste simulant (Vinokurov et al. 2009).

PCT data available in Table 7.13 include results for waste forms made with Hanford Site tank supernatant waste simulant (Wagh et al. 2003); ${ }^{99}$ Tc eluent waste simulant (Singh et al. 2006); WTP HSW simulant and INTEC SBW simulants (Russell et al. 2006); and Hanford Site tank supernatant waste and Mayak supernatant waste simulant (Vinokurov et al. 2009). In all cases, the leachability index and 
diffusivity results met or exceeded applicable standards. Applicable standards are not currently available for PCTs and results are included for information only.

Leachability data for Ceramicrete waste forms fabricated with simulated WTP secondary waste streams are shown in Table 7.14 (Singh et al. 2011). The results in Table 7.14 are for tests conducted for 60 days, except for the baseline samples (bold) that were conducted for 90 days. The waste form compositions, simulated WTP secondary waste stream compositions, and waste loadings are available in Singh (2011). The leachability data are presented in terms of leachability index (ANSI/ANS-16.1 [ANS 1986]). Leachant solutions were analyzed for the radioactive surrogates, I and $\mathrm{Re}$, and $\mathrm{Mg}, \mathrm{Na}, \mathrm{P}, \mathrm{Si}$, and Ag. In most cases, these results met or exceeded applicable standards. Iodine was below the detection limit in all leachates. Using the detection limit of $5 \mathrm{ppb}$, the worst-case LI values for I ranged from $>5.8$ to $>8.2$. The LI values calculated for Re ranged from 7.9 to 9.0 with no specific trend found with waste simulant or filler type. LI values for $\mathrm{Mg}, \mathrm{P}$, and $\mathrm{Si}$ ranged from 8.3 to 12.6, indicating good durability for all the waste forms. The LI calculated for Na ranged from 7.6 to 10.4. The ANS 16.1 test results indicate that the waste forms effectively contain the radionuclide surrogates Re and I at simulant waste loadings as high as $20 \mathrm{wt} . \%$.

It is noteworthy that that some degradation of the waste forms was observed in the samples post ANS 16.1 tests. Fine cracks were observed in samples with fly ash and $\mathrm{CaSiO}_{3}$ filler. Samples with fly ash + slag filler showed the most pronounced cracking. Several explanations were given as possible reasons for the occurance of this cracking. The first possible explanation was that swelling of the zeolite beads over time may have caused cracking. It was also indicated that unreacted $\mathrm{MgO}$ powder in the waste could hydrate to form $\mathrm{Mg}(\mathrm{OH})_{2}$ during the ANS 16.1 or water immersion tests causing swelling and cracking. Another possibility indicated was that because the waste simulants are rich in $\mathrm{Na}$ a reaction between the zerolite and the pore fluid could form hydous amorphous sodium silicate resulting in expansion and cracking. In spite of the cracks, release of radionuclide surrogates did not increase indicating chemical binding of the species in the waste form was effective.

\subsection{Weight Loss Measurements}

As part of the water immersion testing, weight loss measurements of Ceramicrete waste forms fabricated with simulated WTP secondary waste streams were made (Singh et al. 2011). These data, shown in Table 7.15, are not part of the IDF waste acceptance criteria but are included for data completeness. Weight loss for the samples was determined at 1,2, and 3 month intervals. Results indicate the greatest weight loss occurs during the first month, with losses ranged from $5 \%$ to $15 \%$. Subsequent weight losses were significantly less. Depending on the sample composition, the additional weight losses that occurred during the subsequent two months ranged from $2 \%$ to $3 \%$. It appears that the waste forms fabricated with the $\mathrm{CaSiO}_{3}$ filler exhibited slightly higher weight loss compared to other filler compositions. It was suggested that the weight loss was due to removal of unreacted binder powders at the surfaces of the waste forms (Singh et al. 2011). 
Table 7.13. Leachability Index, Diffusivity (ANSI/ANS-16.1), and Leaching Rate Results (PCT, $90^{\circ} \mathrm{C}$ except where noted) for Ceramicrete Waste Forms

\begin{tabular}{|c|c|c|c|c|c|}
\hline $\begin{array}{l}\text { Waste Type/ } \\
\text { Loading }\end{array}$ & $\begin{array}{l}\text { Actual Waste/ } \\
\text { Simulant/Spikes }\end{array}$ & $\begin{array}{l}\text { Leachability Index (LI) } \\
\text { ANSI/ANS-16.1 }\end{array}$ & $\begin{array}{l}\text { Diffusivity } \\
\left(\mathrm{cm}^{2} / \mathrm{s}\right)\end{array}$ & $\begin{array}{c}\text { Normalized Leaching Rate } \\
\left(\mathrm{g} / \mathrm{m}^{2} \text { day) PCT }\right.\end{array}$ & Reference \\
\hline $\begin{array}{l}\text { Surrogate salt waste } \\
\left(\mathrm{NaNO}_{3} \text { and } \mathrm{NaCl}\right) \text {, } \\
58 \text { and } 70 \text { wt.\% }\end{array}$ & $\begin{array}{l}\text { Both } \mathrm{NO}_{3}{ }^{-} \text {and } \mathrm{Cl}^{-} \text {wastes } \\
\text { contained } \mathrm{Fe}_{2} \mathrm{O}_{3}, \mathrm{Al}(\mathrm{OH})_{3} \text {, } \\
\mathrm{Na}_{3} \mathrm{PO}_{4}, \mathrm{Ca}_{2} \mathrm{SiO}_{4} \text {, and water } \\
\text { as major components, } \mathrm{NaCl} \text {, } \\
\mathrm{CaSO}_{4} \text {, and } \mathrm{NaNO}_{3} \text { as salts; } \\
\text { and } \mathrm{Pb} \mathrm{Cr}, \mathrm{Hg}, \mathrm{Cd} \text {, and } \mathrm{Ni} \\
\text { (up to } 800-900 \text { ppm) as } \\
\text { heavy metals in each of the } \\
\text { contaminant oxides, } \\
\text { tricloroethylene }\end{array}$ & $\begin{array}{c}7.2-\mathrm{NO}_{3}^{-} \\
\left(\mathrm{NO}_{3} \text { waste, } 58 \text { wt.\% loading) }\right. \\
8.9-\mathrm{Cl}^{-} \\
\text {(Cl waste, } 58 \text { wt.\% loading) }\end{array}$ & $\begin{array}{l}6.31 \times 10^{-8} \mathrm{NO}_{3}^{-} \text {waste }(58 \text { wt. } \% \\
\text { loading) } \\
\begin{array}{l}1.26 \times 10^{-9} \mathrm{Cl}^{-} \text {waste }(60 \text { wt. } \% \\
\text { loading) }\end{array}\end{array}$ & & $\begin{array}{l}\text { Wagh et al. } \\
(2001)\end{array}$ \\
\hline $\begin{array}{l}\text { Hanford tank } \\
\text { supernatant waste } \\
\text { simulant, } 39.8 \text { wt.\% } \\
\text { loading }\end{array}$ & $\begin{array}{l}17 \text { wt.\% } \mathrm{Na}, 11.5 \text { wt.\% } \mathrm{NO}_{3}^{-} \text {, } \\
\text { pH=13.7, } \mathrm{Cs}, \mathrm{Ba}, \mathrm{Re}, \mathrm{Cd} \\
(2.3 \mathrm{ppm}), \mathrm{Cr}(938 \mathrm{ppm}), \mathrm{Ag} \\
(11.5 \mathrm{ppm}), \mathrm{Pb}(37 \mathrm{ppm}), \text { and } \\
\mathrm{Zn}(7.04 \mathrm{ppm})\end{array}$ & & & $\begin{array}{c}\mathrm{Mg}-1.4 \times 10^{-6} \\
\mathrm{~K}-0.009 \\
\mathrm{P}-0.006 \\
\mathrm{Na}-0.008 \\
\mathrm{NO}_{3}^{-}-0.077\end{array}$ & $\begin{array}{l}\text { Wagh et al. } \\
(2003)\end{array}$ \\
\hline $\begin{array}{l}{ }^{99} \mathrm{Tc} \text { eluent waste } \\
\text { simulant with and } \\
\text { without } \mathrm{SnCl}_{2} \\
\text { stabilization, } \\
36 \text { wt.\% loading }\end{array}$ & $\begin{array}{l}1 \mathrm{M} \mathrm{NaOH}, 1 \mathrm{M} \\
\text { ethylenediamine, } 0.005 \mathrm{M} \\
\mathrm{Sn}(\mathrm{II}), 20-150 \mathrm{ppm} \mathrm{Tc} . \\
\text { Prepared in anoxic (nitrogen) } \\
\text { atmosphere and leach tests } \\
\text { conducted in anoxic } \\
\text { (nitrogen) atmosphere }\end{array}$ & $\begin{array}{c}\text { 8.92-Tc }(20 \mathrm{ppm} \mathrm{Tc}) \\
8.53-\mathrm{Tc}(40 \mathrm{ppm} \mathrm{Tc}) \\
11.54-\mathrm{Tc}(20 \mathrm{ppm} \mathrm{Tc}+\mathrm{Sn}) \\
11.27-\mathrm{Tc}(40 \mathrm{ppm} \mathrm{Tc}+\mathrm{Sn}) \\
14.42-\mathrm{Tc}(124 \mathrm{ppm} \mathrm{Tc}+\mathrm{Sn}) \\
14.6-\mathrm{Tc}\left(41 \mathrm{ppm} \mathrm{Tc} \mathrm{pct}_{\mathrm{pct}}+\mathrm{Sn}\right) \\
13.3-\mathrm{Tc}\left(164 \mathrm{ppm} \mathrm{Tc} \mathrm{pct}_{\mathrm{pr}}+\mathrm{Sn}\right) \\
14.6-\mathrm{Tc}\left(903 \mathrm{ppm} \mathrm{Tc} \mathrm{pct}_{\mathrm{pct}}+\mathrm{Sn}\right)\end{array}$ & $\begin{array}{c}1.2 \times 10^{-9}-\mathrm{Tc}(20 \mathrm{ppm} \mathrm{Tc}) \\
2.95 \times 10^{-9}-\mathrm{Tc}(40 \mathrm{ppm} \mathrm{Tc}) \\
2.9 \times 10^{-12}-\mathrm{Tc}(20 \mathrm{ppm} \mathrm{Tc}+\mathrm{Sn}) \\
5.4 \times 10^{-12}-\mathrm{Tc}(40 \mathrm{ppm} \mathrm{Tc}+\mathrm{Sn}) \\
3.8 \times 10^{-15}-\mathrm{Tc}(124 \mathrm{ppm} \mathrm{Tc}+\mathrm{Sn}) \\
2.2 \times 10^{-14}-\mathrm{Tc}\left(41 \mathrm{ppm} \mathrm{Tc} \mathrm{pct}_{\mathrm{pct}}+\mathrm{Sn}\right) \\
2.3 \times 10^{-13}-\mathrm{Tc}\left(164 \mathrm{ppm} \mathrm{Tc} \mathrm{pct}_{\mathrm{pct}}+\mathrm{Sn}\right) \\
7.2 \times 10^{-15}-\mathrm{Tc}\left(903 \mathrm{ppm} \mathrm{Tc} \mathrm{c}_{\mathrm{pct}}+\mathrm{Sn}\right)\end{array}$ & $\begin{array}{c}25^{\circ} \mathrm{C} \\
0.0039-\mathrm{Tc}\left(40 \mathrm{ppm} \mathrm{Tc} c_{\mathrm{pct}}+\mathrm{Sn}\right) \\
0.0085-\mathrm{Tc}\left(164 \mathrm{ppm} \mathrm{Tc} \mathrm{pct}_{\mathrm{pct}}+\mathrm{Sn}\right) \\
0.0011-\mathrm{Tc}\left(903 \mathrm{ppm} \mathrm{Tc} \mathrm{pct}_{\mathrm{pct}}+\mathrm{Sn}\right) \\
90^{\circ} \mathrm{C} \\
0.072-\mathrm{Tc}\left(40 \mathrm{ppm} \mathrm{Tc} \mathrm{pct}_{\mathrm{pct}}+\mathrm{Sn}\right) \\
0.11-\mathrm{Tc}\left(164 \mathrm{ppm} \mathrm{Tc} \mathrm{pct}_{\mathrm{pct}}+\mathrm{Sn}\right) \\
0.036-\mathrm{Tc}(903 \mathrm{ppm} \mathrm{Tc} \mathrm{pct}+\mathrm{Sn})\end{array}$ & $\begin{array}{l}\text { Singh et al. } \\
(2006)\end{array}$ \\
\hline $\begin{array}{l}\text { WTP HSW } \\
\text { simulant, } 25.8 \text { wt.\% }\end{array}$ & $\begin{array}{l}\mathrm{Na}(45.2 \mathrm{~g} / \mathrm{L}), \mathrm{CO}_{3}^{-2}(60 \mathrm{~g} / \mathrm{L}) \\
\mathrm{NO}_{3}^{-}(1.12 \mathrm{~g} / \mathrm{L}), \mathrm{OH}^{-}(1.6 \\
\mathrm{g} / \mathrm{L}), \mathrm{TOC}(13.9 \mathrm{~g} / \mathrm{L}), \mathrm{Al} \\
(0.32 \mathrm{~g} / \mathrm{L}), \mathrm{Cr}, \mathrm{Ag}, \mathrm{Cd}, \mathrm{Re}, \mathrm{I} \\
\mathrm{Hg}, \mathrm{Pb}\end{array}$ & $\begin{array}{c}8.08,8.20-\mathrm{Na} \\
7.02,7.36-\mathrm{Re} \\
>3.60,>3.60-\mathrm{I} \\
12.7-\mathrm{Re}(\mathrm{CH} 2 \mathrm{MHILL}) \\
11.2-\mathrm{I}(\mathrm{CH} 2 \mathrm{MHILL}) \\
\text { (CH2MHILL work at } 7 \text { days } \\
\text { and higher initial Re and I } \\
\text { concentrations) }\end{array}$ & & $\begin{array}{c}\mathrm{Na}-14.76,14.76,250,284 \\
\mathrm{~K}-44.06,42.62,403,427 \\
\mathrm{Si}-0.240,0.257,8.81,6.64 \\
\mathrm{Mg}-0.003,0.002,0.228,0.119 \\
\mathrm{P}-16.84,16.51,202,203\end{array}$ & $\begin{array}{l}\text { Russell et al. } \\
\text { (2006) }\end{array}$ \\
\hline
\end{tabular}


Table 7.13. (contd)

\begin{tabular}{|c|c|c|c|c|c|}
\hline $\begin{array}{l}\text { Waste Type/ } \\
\text { Loading }\end{array}$ & $\begin{array}{l}\text { Actual Waste/ } \\
\text { Simulant/Spikes }\end{array}$ & $\begin{array}{l}\text { Leachability Index (LI) } \\
\text { ANSI/ANS-16.1 }\end{array}$ & $\begin{array}{l}\text { Diffusivity } \\
\left(\mathrm{cm}^{2} / \mathrm{s}\right)\end{array}$ & $\begin{array}{l}\text { Normalized Leaching Rate } \\
\qquad\left(\mathrm{g} / \mathrm{m}^{2} \text { day }\right) \text { PCT }\end{array}$ & Reference \\
\hline $\begin{array}{l}\text { INTEC SBW } \\
\text { simulant, } 47.4 \text { wt. } \%\end{array}$ & $\begin{array}{l}\mathrm{Na}(43.2 \mathrm{~g} / \mathrm{L}), \mathrm{NO}_{3}{ }^{-}(269 \\
\mathrm{g} / \mathrm{L}), \mathrm{Al}(17.8 \mathrm{~g} / \mathrm{L}), \mathrm{SO}_{4}^{-2} \\
(5.15 \mathrm{~g} / \mathrm{L}), \mathrm{Ca}(1.46 \mathrm{~g} / \mathrm{L}), \mathrm{K} \\
(6.8 \mathrm{~g} / \mathrm{L}), \mathrm{Cl}^{-}(1.15 \mathrm{~g} / \mathrm{L}), \mathrm{F}^{-} \\
(0.83 \mathrm{~g} / \mathrm{L}), \mathrm{B}, \mathrm{Mg}, \mathrm{Cr}, \mathrm{Mn}, \\
\mathrm{Fe}, \mathrm{Cd}, \mathrm{Cs}, \mathrm{Ce}, \mathrm{Hg}, \mathrm{Pb}, \mathrm{Re}, \mathrm{I}\end{array}$ & $\begin{array}{c}7.59,7.56-\mathrm{Na} \\
7.41,7.42-\mathrm{Re} \\
>5.55,>5.54-\mathrm{I}\end{array}$ & & $\begin{array}{c}\mathrm{Na}-26.56,28.08,358,360 \\
\mathrm{~K}-44.40,45.11,547,539 \\
\mathrm{Si}-0.335,0.048,1.20,1.28 \\
\mathrm{Mg}-0.008,0.008,0.538,0.474 \\
\mathrm{P}-7.08,7.32,92.5,94.0\end{array}$ & $\begin{array}{l}\text { Russell et al. } \\
\text { (2006) }\end{array}$ \\
\hline $\begin{array}{l}\text { Hanford tank } \\
\text { supernatant waste } \\
\text { simulant, } 35 \text { wt.\% } \\
\text { loading }\end{array}$ & $\begin{array}{l}256 \mathrm{~g} / \mathrm{L} \mathrm{Na}, 168 \mathrm{~g} / \mathrm{L} \mathrm{NO}_{3}, \\
113 \mathrm{~g} / \mathrm{L} \mathrm{NO}, 83.7 \mathrm{~g} / \mathrm{L} \mathrm{OH}_{2} \\
\mathrm{CO}_{3}^{-2}, \mathrm{Al}, \mathrm{Cl}, \mathrm{Cs}, \mathrm{Sr}, \mathrm{SO}_{4}^{-2} \\
\mathrm{Cr}, \mathrm{Pb}, \mathrm{Cd}, \mathrm{K}, \mathrm{Am}, \mathrm{Ce}, \mathrm{Pu} \\
\mathrm{Np}, \mathrm{Am}, \mathrm{Sr}, \mathrm{Cs}, \mathrm{Tc}, \mathrm{I}, \mathrm{Se}\end{array}$ & $\begin{array}{c}{ }^{237} \mathrm{~Np}-12.8 \\
{ }^{239} \mathrm{Pu}-13.5 \\
{ }^{90} \mathrm{Sr}-10.9 \\
{ }^{137} \mathrm{Cs}-11.4 \\
{ }^{99} \mathrm{Tc}-9.9 \\
{ }^{131} \mathrm{I}-11.2 \\
{ }^{75} \mathrm{Se}-9.6\end{array}$ & & $\begin{array}{c}\mathrm{Mg}-6.6 \times 10^{-5} \\
\mathrm{~K}-0.024 \\
\mathrm{P}-0.0072 \\
\mathrm{Na}-0.024 \\
\mathrm{NO}_{3}^{-}-0.038 \\
\mathrm{Zn}-<0.012 \\
\mathrm{Cr}-8.5 \times 10^{-5} \\
\mathrm{Ni}-7.0 \times 10^{-5} \\
\mathrm{Cd}-0.0018 \\
\mathrm{~Pb}-7.3 \times 10^{-4}\end{array}$ & $\begin{array}{l}\text { Vinokurov } \\
\text { et al. (2009) }\end{array}$ \\
\hline $\begin{array}{l}\text { Mayak supernatant } \\
\text { waste simulant, } \\
43 \text { wt.\% loading }\end{array}$ & $\begin{array}{l}296 \mathrm{~g} / \mathrm{L} \mathrm{Na}^{-}, 99 \mathrm{~g} / \mathrm{L} \mathrm{NO}_{3}^{-} \\
38 \mathrm{~g} / \mathrm{L} \mathrm{NO}_{2}^{-}, 91.5 \mathrm{~g} / \mathrm{L} \mathrm{OH}^{-} \\
\mathrm{Al}, \mathrm{Cl}^{-}, \mathrm{SO}_{4}^{-2}, \mathrm{Cr}, \mathrm{Cs}, \mathrm{Sr}, \mathrm{Tc} \\
\text { I, Se }\end{array}$ & $\begin{array}{l}{ }^{90} \mathrm{Sr}-11.1 \\
{ }^{137} \mathrm{Cs}-13.0 \\
{ }^{131} \mathrm{I}-7.9\end{array}$ & & $\begin{array}{l}\mathrm{Mg}-4.1 \times 10^{-6} \\
\mathrm{~K}-0.019 \\
\mathrm{P}-0.0063 \\
\mathrm{Na}-0.017 \\
\mathrm{NO}_{3}^{-}-0.031\end{array}$ & $\begin{array}{l}\text { Vinokurov } \\
\text { et al. (2009) }\end{array}$ \\
\hline
\end{tabular}


Table 7.14. Leaching Index Results from ANS 16.1 Tests Conducted on Ceramicrete Waste Forms Fabricated with WTP Secondary Waste Stream Simulants and Blank Samples (Singh et al. 2011)

\begin{tabular}{|c|c|c|c|c|c|c|c|c|}
\hline Sample & $\begin{array}{c}\text { Waste } \\
\text { Simulant }\end{array}$ & $\mathrm{Mg}$ & $\mathrm{Na}$ & $\mathrm{P}$ & $\mathrm{Si}$ & $\mathrm{Ag}$ & $\operatorname{Re}$ & $I^{(a)}$ \\
\hline 45FA+Blank & Blank & 10.5 & - & 8.4 & 12.5 & 16.3 & - & - \\
\hline 45FA+Blank & Blank & 10.5 & - & 8.4 & 12.5 & 16.2 & - & - \\
\hline 45FA+20WS(B) & B & 11.0 & 8.1 & 8.5 & 12.4 & 16.6 & 8.6 & $>6.5$ \\
\hline 45FA+20WS(B) & B & 10.8 & 8.1 & 8.3 & 12.2 & 14.5 & 8.6 & $>6.5$ \\
\hline 45FA+15WS(B) & B & 10.6 & 8.2 & 8.3 & 12.2 & 16.1 & 8.6 & $>6.2$ \\
\hline 45FA+15WS(B) & B & 10.7 & 8.2 & 8.4 & 12.3 & 16.4 & 8.6 & $>6.2$ \\
\hline $45 \mathrm{CaSi}+20 \mathrm{WS}(\mathrm{B})$ & B & 10.9 & 7.6 & 8.4 & 11.3 & 17.2 & 8.4 & $>6.6$ \\
\hline 45CaSi+20WS(B) & B & 11.0 & 7.6 & 8.5 & 11.3 & 17.7 & 8.4 & $>6.6$ \\
\hline 45CaSi+15WS(B) & B & 11.0 & 7.7 & 8.5 & 11.3 & 16.9 & 8.3 & $>6.2$ \\
\hline 45CaSi+15WS(B) & B & 11.0 & 7.7 & 8.5 & 11.4 & 17.8 & 8.3 & $>6.3$ \\
\hline 45CaSi+Blank & Blank & 11.8 & 10.2 & 9.0 & 11.9 & 17.7 & - & - \\
\hline 45CaSi+Blank & Blank & 11.9 & 10.4 & 9.1 & 11.7 & 17.7 & - & - \\
\hline 35FA+10Slag+15WS(B) & B & 11.3 & 8.0 & 8.5 & 12.2 & 17.2 & 8.5 & $>6.3$ \\
\hline 35FA+10Slag+15WS(B) & B & 11.3 & 8.0 & 8.5 & 12.2 & 17.1 & 8.5 & $>6.3$ \\
\hline 35FA+10Slag+Blank & Blank & 11.5 & 9.6 & 8.8 & 12.2 & 17.2 & - & - \\
\hline 35FA+10Slag+Blank & Blank & 11.6 & 9.7 & 8.9 & 12.6 & 17.2 & - & - \\
\hline 45FA+20WS(C1) & $\mathrm{C} 1$ & 9.4 & 8.0 & 8.4 & 12.3 & 16.0 & 8.7 & $>6.2$ \\
\hline 45FA+20WS(C1) & $\mathrm{C} 1$ & 11.1 & 8.0 & 8.4 & 12.3 & 16.1 & 8.8 & $>6.2$ \\
\hline $45 \mathrm{FA}+15 \mathrm{WS}(\mathrm{C} 1)$ & $\mathrm{C} 1$ & 10.7 & 8.0 & 8.3 & 12.2 & 16.1 & 8.6 & $>5.8$ \\
\hline $45 \mathrm{FA}+15 \mathrm{WS}(\mathrm{C} 1)$ & $\mathrm{C} 1$ & 10.7 & 8.0 & 8.3 & 12.2 & 16.8 & 8.6 & $>5.8$ \\
\hline $45 \mathrm{CaSi}+20 \mathrm{WS}(\mathrm{C} 1)$ & $\mathrm{C} 1$ & 11.2 & 7.6 & 8.5 & 11.8 & 17.4 & 8.1 & $>6.2$ \\
\hline $45 \mathrm{CaSi}+20 \mathrm{WS}(\mathrm{C} 1)$ & $\mathrm{C} 1$ & 11.2 & 7.6 & 8.5 & 11.6 & 17.5 & 8.1 & $>6.2$ \\
\hline $45 \mathrm{CaSi}+15 \mathrm{WS}(\mathrm{C} 1)$ & $\mathrm{C} 1$ & 11.3 & 7.6 & 8.6 & 11.7 & 17.7 & 8.0 & $>5.9$ \\
\hline $45 \mathrm{CaSi}+15 \mathrm{WS}(\mathrm{C} 1)$ & $\mathrm{C} 1$ & 11.3 & 7.6 & 8.5 & 11.6 & 17.7 & 8.1 & $>5.9$ \\
\hline $35 \mathrm{FA}+10$ Slag $+15 \mathrm{WS}(\mathrm{C} 1)$ & $\mathrm{C} 1$ & 11.4 & 10.0 & 8.5 & 12.3 & 17.7 & 8.6 & $>8.0$ \\
\hline 35FA+10Slag+15WS(C1) & $\mathrm{C} 1$ & 11.6 & 8.1 & 8.6 & 12.4 & 17.7 & 8.5 & $>5.8$ \\
\hline $45 \mathrm{CaSi}+20 \mathrm{WS}(\mathrm{C} 2)$ & $\mathrm{C} 2$ & 11.3 & 7.6 & 8.5 & 11.6 & 17.0 & 8.1 & $>6.4$ \\
\hline $45 \mathrm{CaSi}+20 \mathrm{WS}(\mathrm{C} 2)$ & $\mathrm{C} 2$ & 11.4 & 7.6 & 8.6 & 11.7 & 17.0 & 7.9 & $>6.4$ \\
\hline $45 \mathrm{CaSi}+15 \mathrm{WS}(\mathrm{C} 2)$ & $\mathrm{C} 2$ & 11.3 & 7.6 & 8.6 & 11.6 & 17.0 & 8.0 & $>6.1$ \\
\hline $45 \mathrm{CaSi}+15 \mathrm{WS}(\mathrm{C} 2)$ & $\mathrm{C} 2$ & 11.4 & 7.7 & 8.7 & 11.8 & 17.0 & 7.9 & $>6.1$ \\
\hline 45FA+20WS(M) & M & 10.6 & 8.1 & 8.5 & 12.3 & 17.0 & 8.9 & $>8.1$ \\
\hline 45FA+20WS(M) & M & 10.6 & 8.1 & 8.5 & 12.3 & 15.0 & 9.0 & $>8.2$ \\
\hline 45FA+15WS(M) & $\mathrm{M}$ & 10.7 & 8.1 & 8.5 & 12.3 & 16.7 & 8.7 & $>7.9$ \\
\hline 45FA+15WS(M) & $\mathrm{M}$ & 10.6 & 8.1 & 8.5 & 12.3 & 16.8 & 8.7 & $>7.9$ \\
\hline $45 \mathrm{CaSi}+20 \mathrm{WS}(\mathrm{M})$ & M & 11.0 & 7.7 & 8.5 & 11.5 & 17.4 & 8.2 & $>8.2$ \\
\hline $45 \mathrm{CaSi}+20 \mathrm{WS}(\mathrm{M})$ & M & 11.1 & 7.7 & 8.5 & 11.5 & 17.3 & 8.1 & $>8.2$ \\
\hline 35FA+10Slag +15WS(M) & $\mathrm{M}$ & 10.9 & 8.1 & 8.7 & 12.5 & 17.1 & 8.8 & $>7.9$ \\
\hline 35FA+10Slag+15WS(M) & $\mathrm{M}$ & 10.9 & 8.1 & 8.6 & 12.4 & 17.1 & 8.9 & $>7.9$ \\
\hline
\end{tabular}

(a) Iodine was found below the detection level $(<5 \mathrm{ppb})$. Detection level value was used to determine the LI. 
Table 7.15. Weight Loss Results Determined in Water Immersion Tests for Ceramicrete Waste Forms Fabricated with WTP Secondary Waste Stream Simulants and Blank Samples (Singh et al. 2011)

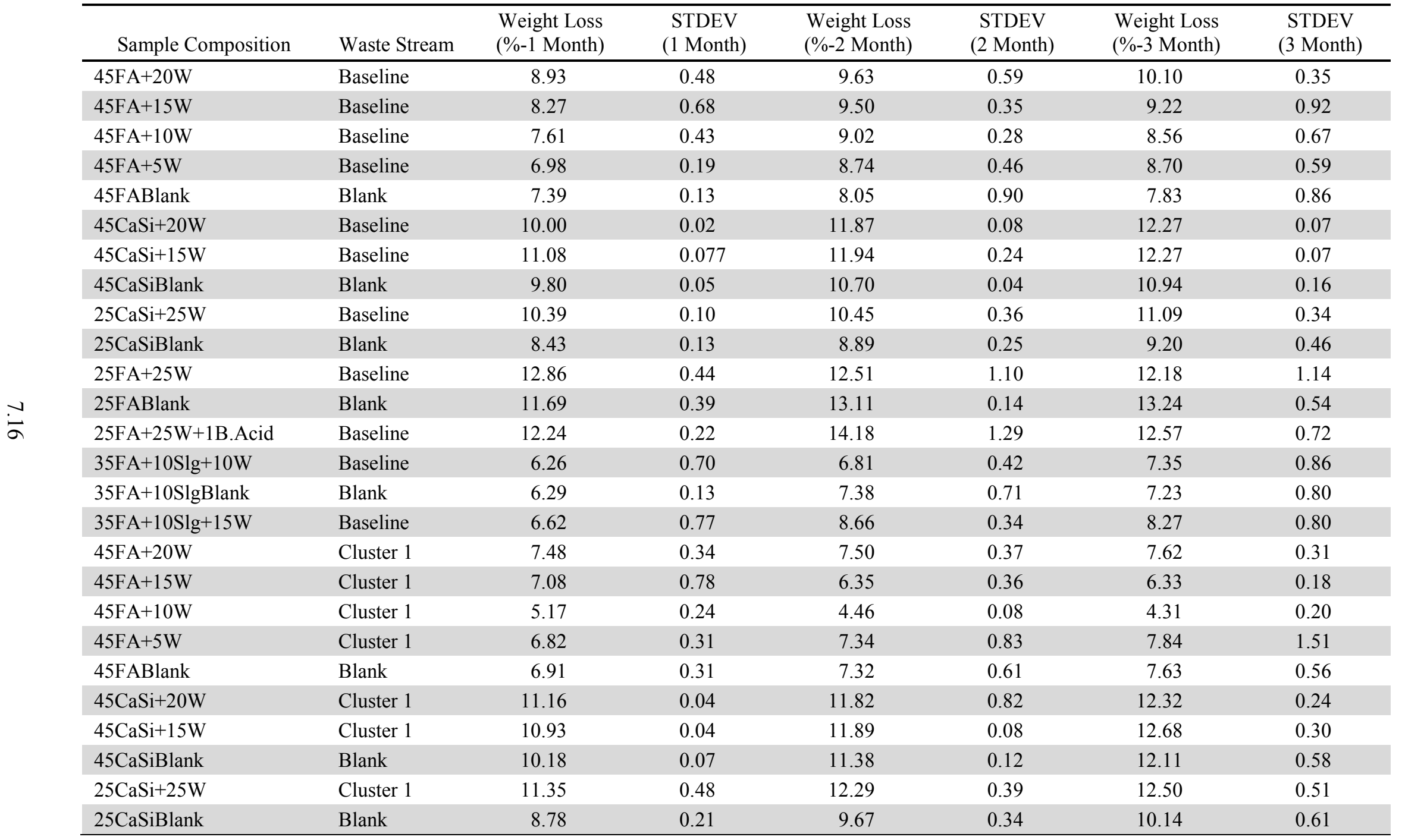


Table 7.15. (contd)

\begin{tabular}{|c|c|c|c|c|c|c|c|}
\hline Sample Composition & Waste Stream & $\begin{array}{l}\text { Weight Loss } \\
\text { (\%-1 Month) }\end{array}$ & $\begin{array}{c}\text { STDEV } \\
\text { (1 Month) }\end{array}$ & $\begin{array}{l}\text { Weight Loss } \\
\text { (\%-2 Month) }\end{array}$ & $\begin{array}{c}\text { STDEV } \\
\text { (2 Month) }\end{array}$ & $\begin{array}{l}\text { Weight Loss } \\
\text { (\%-3 Month) }\end{array}$ & $\begin{array}{l}\text { STDEV } \\
\text { (3 Month) }\end{array}$ \\
\hline $25 \mathrm{FA}+25 \mathrm{~W}$ & Cluster 1 & 13.77 & 0.74 & 14.71 & 0.20 & 14.89 & 0.22 \\
\hline 25FABlank & Blank & 12.23 & 0.52 & 11.37 & 1.37 & 12.13 & 0.82 \\
\hline $25 \mathrm{FA}+25 \mathrm{~W}+1 \mathrm{~B} . \mathrm{Acid}$ & Cluster 1 & 14.30 & 0.49 & 15.32 & 0.79 & 15.06 & 0.24 \\
\hline $35 \mathrm{FA}+10 \mathrm{Slg}+10 \mathrm{~W}$ & Cluster 1 & 4.93 & 0.98 & 5.51 & 0.42 & 5.66 & 0.60 \\
\hline 35FA+10SlgBlank & Blank & 6.29 & 0.13 & 7.38 & 0.71 & 7.23 & 0.80 \\
\hline $35 \mathrm{FA}+10 \mathrm{Slg}+15 \mathrm{~W}$ & Cluster 1 & 6.12 & 0.20 & 7.31 & 0.44 & 6.81 & 0.09 \\
\hline $45 \mathrm{FA}+20 \mathrm{~W}$ & Cluster 2 & 9.81 & 0.61 & 8.70 & 0.18 & 8.47 & 0.82 \\
\hline $45 \mathrm{FA}+15 \mathrm{~W}$ & Cluster 2 & 8.87 & 0.34 & 7.82 & 0.33 & 8.02 & 0.08 \\
\hline $45 \mathrm{FA}+10 \mathrm{~W}$ & Cluster 2 & 9.02 & 1.84 & 9.06 & 0.30 & 8.20 & 1.35 \\
\hline $45 \mathrm{FA}+5 \mathrm{~W}$ & Cluster 2 & 8.85 & 1.79 & 7.32 & 0.66 & 6.56 & 1.02 \\
\hline 45FABlank & Blank & 7.39 & 0.13 & 8.05 & 0.59 & 7.83 & 0.86 \\
\hline $45 \mathrm{CaSi}+20 \mathrm{~W}$ & Cluster 2 & 11.97 & 0.06 & 12.04 & 0.16 & 12.59 & 0.13 \\
\hline $45 \mathrm{CaSi}+15 \mathrm{~W}$ & Cluster 2 & 11.83 & 0.86 & 12.00 & 0.38 & 12.67 & 0.05 \\
\hline 45CaSiBlank & Blank & 9.80 & 0.05 & 10.70 & 0.04 & 10.94 & 0.16 \\
\hline $25 \mathrm{CaSi}+25 \mathrm{~W}$ & Cluster 2 & 11.74 & 0.23 & 11.43 & 0.67 & 13.61 & 2.77 \\
\hline 25CaSiBlank & Blank & 8.43 & 0.13 & 8.89 & 0.08 & 9.20 & 0.46 \\
\hline $25 \mathrm{FA}+25 \mathrm{~W}$ & Cluster 2 & 11.62 & 1.82 & 14.94 & 5.96 & 13.44 & 0.84 \\
\hline 25FABlank & Blank & 11.69 & 0.39 & 13.11 & 0.08 & 13.24 & 0.54 \\
\hline $25 \mathrm{FA}+25 \mathrm{~W}+1 \mathrm{~B}$. Acid & Cluster 2 & 11.32 & 3.83 & 10.65 & 5.10 & 17.42 & 7.41 \\
\hline $35 \mathrm{FA}+10 \mathrm{Slg}+10 \mathrm{~W}$ & Cluster 2 & 5.99 & 1.33 & 6.89 & 0.35 & 5.78 & 0.93 \\
\hline 35FA+10SlgBlank & Blank & 6.29 & 0.13 & 7.38 & 0.71 & 7.23 & 0.80 \\
\hline $35 \mathrm{FA}+10 \mathrm{Slg}+15 \mathrm{~W}$ & Cluster 2 & 7.62 & 0.59 & 7.30 & 0.27 & 7.89 & 0.54 \\
\hline $45 \mathrm{FA}+20 \mathrm{~W}$ & Mixed & 10.35 & 0.47 & 8.67 & 0.49 & 9.63 & 0.69 \\
\hline $45 \mathrm{FA}+15 \mathrm{~W}$ & Mixed & 10.20 & 0.63 & 9.09 & 1.08 & 8.65 & 1.34 \\
\hline $45 \mathrm{FA}+10 \mathrm{~W}$ & Mixed & 9.33 & 0.54 & 8.28 & 0.15 & 8.79 & 0.92 \\
\hline $45 \mathrm{FA}+5 \mathrm{~W}$ & Mixed & 9.46 & 0.41 & 8.45 & 0.82 & 8.79 & 0.72 \\
\hline
\end{tabular}


Table 7.15. (contd)

\begin{tabular}{|c|c|c|c|c|c|c|c|}
\hline Sample Composition & Waste Stream & $\begin{array}{l}\text { Weight Loss } \\
\text { (\%-1 Month) }\end{array}$ & $\begin{array}{c}\text { STDEV } \\
\text { (1 Month) }\end{array}$ & $\begin{array}{l}\text { Weight Loss } \\
\text { (\%-2 Month) }\end{array}$ & $\begin{array}{c}\text { STDEV } \\
\text { (2 Month) }\end{array}$ & $\begin{array}{l}\text { Weight Loss } \\
\text { (\%-3 Month) }\end{array}$ & $\begin{array}{c}\text { STDEV } \\
\text { (3 Month) }\end{array}$ \\
\hline $45 \mathrm{CaSi}+20 \mathrm{~W}$ & Mixed & 13.01 & 0.18 & 14.87 & 0.11 & 14.38 & 0.12 \\
\hline 45CaSiBlank & Blank & 9.80 & 0.05 & 10.70 & 0.04 & 10.94 & 0.16 \\
\hline $25 \mathrm{CaSi}+25 \mathrm{~W}$ & Mixed & 12.55 & 1.30 & 14.27 & 1.24 & 12.21 & 1.33 \\
\hline 25CaSiBlank & Blank & 8.43 & 0.13 & 8.89 & 0.08 & 9.20 & 0.46 \\
\hline $25 \mathrm{FA}+25 \mathrm{~W}+1 \mathrm{~B}$. Acid & Mixed & 20.67 & 1.63 & 17.13 & 4.34 & 20.80 & 0.24 \\
\hline $35 \mathrm{FA}+10 \mathrm{Slg}+10 \mathrm{~W}$ & Mixed & 9.19 & 0.73 & 10.14 & 1.04 & 8.61 & 0.24 \\
\hline 35FA+10SlgBlank & Blank & 6.29 & 0.13 & 7.38 & 0.71 & 7.23 & 0.80 \\
\hline $35 \mathrm{FA}+10 \mathrm{Slg}+15 \mathrm{~W}$ & Mixed & 10.00 & 1.27 & 10.33 & 0.84 & 10.89 & 0.45 \\
\hline
\end{tabular}




\subsection{Summary of Key Ceramicrete Attributes}

Ceramicrete is a relatively new engineering material developed at Argonne National Laboratory to treat radioactive and hazardous waste streams (e.g., Wagh 2004; Wagh et al. 1999a, 2003; Singh et al. 2000). This cement-like waste form can be used to treat solids, liquids, and sludges by chemical immobilization, microencapsulation, and/or macroencapsulation. The Ceramicrete technology is based on chemical reactions between phosphate anions and metal cations to form a strong, dense, durable, and low porosity matrix that immobilizes hazardous and radioactive contaminants as insoluble phosphates and microencapsulates insoluble radioactive components. Ceramicrete is a type of phosphate-bonded ceramic, which are also known as CBPCs. The Ceramicrete binder is formed through an acid-base reaction between calcined magnesium oxide ( $\mathrm{MgO}$; a base) and potassium hydrogen phosphate $\left(\mathrm{KH}_{2} \mathrm{PO}_{4}\right.$; an acid) in aqueous solution. The reaction product sets at room temperature to form a highly crystalline material. During the reaction, the hazardous and radioactive contaminants also react with $\mathrm{KH}_{2} \mathrm{PO}_{4}$ to form highly insoluble phosphates. Small amounts of additives are added to reduce Tc(VII) to less soluble Tc (IV) [ $\mathrm{SnCl}_{2}$ and $\mathrm{Na}_{2} \mathrm{~S}$ ] and to precipitate radioiodine (silver zeolite). The salient characteristics and the results of performance testing of the Ceramicrete waste form are summarized below:

\section{- Waste Loading}

Based on process demonstration testing (Singh et al. 2011), solid waste loading of $\sim 1.2 \mathrm{wt} . \%$ and $\sim 2.2 \mathrm{wt} . \%$ has been achieved using the Hanford secondary waste S1 and S4 simulants, respectively. The $\mathrm{Na}$ loading in both cases was equivalent to $\sim 1 \mathrm{M}$.

\section{- The Critical Parameters for the Ceramicrete Process}

1. There was degradation of the waste forms observed in the samples post ANS 16.1 tests. Fine cracks were observed in samples with fly ash and $\mathrm{CaSiO}_{3}$ filler. Samples with fly ash + slag filler showed the most pronounced cracking. Several explanations were given as possible reasons for the occurance of this cracking. The first possible explanation was that swelling of the zeolite beads over time may have caused cracking. It was also indicated that unreacted $\mathrm{MgO}$ powder in the waste could hydrate to form $\mathrm{Mg}(\mathrm{OH})_{2}$ during the ANS 16.1 or water immersion tests causing swelling and cracking. Another possibility indicated was that because the waste simulants are rich in $\mathrm{Na}$ a reaction between the zerolite and the pore fluid could form hydous amorphous sodium silicate resulting in expansion and cracking. In spite of the cracks, release of radionuclide surrogates did not increase indicating chemical binding of the species in the waste form was effective.

2. Hydrogen generation resulting from radiolytic decomposition of water and organic compounds in Ceramicrete fabricated with secondary waste is not expected to be a significant issue.

3. Preliminary scale-up of the process was conducted up to 2 gallons size waste forms. Use of minimal amounts of boric acid as a set retarder was used to control the mixing time to as much as 35 minutes.

4. The Ceramicrete should set within a couple of hours and should be cured within 24 hours although heat dissipation may take longer depending on the size of the containers.

5. Ceramicrete waste forms fabricated at the lowest fly ash concentration, using the mixed simulant (S4) at the highest waste concentration, and boric acid as a set retarder (sample composition 
$25 \mathrm{FA}+25 \mathrm{~W}+1 \mathrm{~B} . \mathrm{A})$, did not meet the minimum compressive strength requirement for IDF waste acceptance (3.54E6 Pa, 500psi).

\section{- Ceramicrete Flow Sheet}

CH2M HILL developed a concept for a standalone facility for implementing the Ceramicrete process for Hanford secondary liquid wastes (Russell et al. 2006). As part of their Ceramicrete facility concept, an equipment list for the major equipment components was provided. The equipment is sized to process a maximum volume of 800,000 liters of $2 \mathrm{M}$ sodium secondary waste solution every 30 days with a 70 percent total operating efficiency. All vessels were sized to hold their contents at 85 percent capacity. Based on this conceptual design, the estimated cost for construction of the CTF for immobilizing HSW was estimated to be $\$ 48.5$ million (in 2005 dollars).

\section{- Regulatory Leach Tests}

TCLP (EPA Method 1311) results conducted on ceramicrete specimens fabricated with all waste simulants indicated that the concentrations of RCRA metals ( $\mathrm{Ag}, \mathrm{As}, \mathrm{Ba}, \mathrm{Cd}, \mathrm{Cr}, \mathrm{Hg}, \mathrm{Pb}$, and $\mathrm{Se}$ ) in the leachates were well below the UTS 40 CFR 268.48 standards). ANSI/ANS 16.1 leach test results for Re (as a Tc surrogate) and I met the required standards. LI values calculated for Re ranged from 7.9 to 9.0 , with no specific trend found with waste simulant or filler type. Iodine was below the detection limit in all leachates. Using the detection limit of $5 \mathrm{ppb}$, the worst-case LI values for I ranged from $>5.8$ to $>8.2$.

\section{- Compressive Strength}

The only Ceramicrete waste form composition that did not meet the minimum compressive strength requirement for IDF waste acceptance (3.54E6 Pa, 500psi) was 25FA+25W+1B.A (mixed simulant). 


\subsection{References}

ANS. 1986. "American National Standard Measurement of the Leachability in Solidified Low-Level Radioactive Wastes by a Short-Term Test Procedure, Method ANSI/ANS 16.1-1986." American Nuclear Society, La Grange Park, Illinois.

ASTM. 1997. "Standard Test Methods for Determining Chemical Durability of Nuclear, Hazardous, and Mixed Waste Glasses: The Product Consistency Test (PCT), ASTM C 1285-97.” American Society for Testing and Materials, West Conshohocken, Pennsylvania.

Brinker CJ and GW Scherer. 1989. Chapters 1 and 4. In Sol-Gel Science, Academic Press, San Diego, California.

Brown WE and LC Chow. 1986. “A New Calcium Phosphate, Water-Setting Cement.” In Cements Research Progress, PW Brown, ed, Westerville, Ohio, American Ceramic Society, pp. 352-379.

Buj I, J Torras, D Casellas, M Rovira, and J Pablo. 2009. "Effect of Heavy Metals and Water Content on the Strength of Magnesium Phosphate Cements.” Journal of Hazardous Materials 170:345-350.

Buj I, J Torras, M Rovira, and J Pablo. 2010. "Leaching Behaviour of Magnesium Phosphate Cements Containing High Quantities of Heavy Metals.” Journal of Hazardous Materials 175:789-794.

DOE Order 435.1. 1999. "Radioactive Waste Management." U.S. Department of Energy, Washington, D.C.

EPA. 1992. "Method 1311: Toxicity Characteristic Leaching Procedure." In Response, Office of Solid Waste and Emergency, Test Methods for Evaluating Solid Waste, SW-846. U.S. Environmental Protection Agency, Washington, D.C.

EPA. 1995. Guidelines for Classification and Packing Group Assignment of Division 5.1, Materials. CFR CH1 (10-1-95 Ed.), Appendix F to Part 173, U.S. Environmental Protection Agency, Washington, D.C.

Eubank WR. 1951. "Calcination Studies of Magnesium Oxide." Journal of the American Ceramic Society 34(8):225-229.

Fluor Hanford. 2005. Conceptual Design Report for Effluent Treatment Facility Solidification Treatment Unit. HNF-26914, Fluor Hanford, Richland, Washington.

Hunter J. 1981. Zero Potential in Colloid Science. Academic Press, New York.

Josephson GB, LM Bagaasen, JGH Geeting, PA Gauglitz, GJ Lumetta, JS Tixier. 2003. Hanford Mission Acceleration Initiative - Preliminary Testing Recommendations for Supplemental Treatment. PNNL-14005, Rev. 1, Pacific Northwest National Laboratory, Richland, Washington.

NRC. 1991. Technical Position on Waste Form. U.S. Nuclear Regulatory Commission, Washington, D.C. 
Pierce EM, SV Mattigod, RJ Serne, JP Icenhower, RD Scheele, W Um, N Qafoku, and JH Westsik, Jr. 2010a. Review of Potential Candidate Stabilization Technologies for Liquid and Solid Secondary Waste Streams. PNNL-19122, Pacific Northwest National Laboratory, Richland, Washington.

Pierce EM, W Um, KJ Cantrell, MM Valenta, JH Westsik, Jr., RJ Serne, KE Parker. 2010b. Secondary Waste Form Screening Test Results - Cast Stone and Alkali Alumino-Silicate Geopolymer. PNNL-19505, Pacific Northwest National Laboratory, Richland, Washington.

Pourbaix M. 1974. Atlas of Electrochemical Equilibria in Aqueous Solutions. Pergamon Press, New York.

Raymond RE, RW Powell, DW Hamilton, WA Kitchen, BM Mauss, TM Brouns. 2004. Initial Selection of Supplemental Treatment Technologies for Hanford's Low-Activity Tank Waste. RPP-19763, WM-04 Conference, February 29-March 4, 2004, Tucson, Arizona.

Resource Conservation and Recovery Act of 1976. 1976. Public Law 94-580, as amended, 42 USC 6901 et seq. and 42 USC 6927(c) et seq.

RPP-8402. 2005. Integrated Disposal Facility Waste Acceptance Criteria. RPP-8402, Rev. 1, February 23, 2005.

Russell RL, MJ Schweiger, JH Westisk, Jr., PR Hrma, DE Smith, AB Gallegos, MR Telander, and SG Pitman. 2006. Low Temperature Waste Immobilization Testing. PNNL-16052, Rev. 1, Pacific Northwest National Laboratory, Richland, Washington.

Sakar AK. 1991. "Hydration/Dehydration Characteristics of Struvite and Dittmarite Pertaining to Magnesium Ammonium Phosphate Cement System.” Journal of Materials Science 26:2314-2318.

Schwinkendorf WE and CE Cooley. 1999. "Cost of Mixed Low-Level Waste Stabilization Options.” Proceeding of Waste Management 1998, Tucson, Arizona.

Singh D, AS Wagh, JC Cunnane, and JL Mayberry. 1997. "Chemically Bonded Phosphate Ceramics for Low-Level Mixed-Waste Stabilization." Journal of Environmental Science and Health A32(2): 27-541.

Singh D, AS Wagh, M Tlustochowicz, and SY Jeong. 1998. "Phosphate Ceramic Process for Macroencapsulation and Stabilization of Low-Level Debris Wastes.” Waste Management 18:135-143.

Singh D, SY Jeong, K Dwyer and T Abesadze. 2000. "Ceramicrete: A Novel Ceramic Packaging System for Spent-Fuel Transport and Storage." Proceedings of Waste Management $2 \mathrm{~K}$ Conference, Tucson, Arizona, February 27-March 2, 2000.

Singh D, VR Mandalika, SJ Parulekar, and AS Wagh. 2006. "Magnesium Potassium Phosphate Ceramic for ${ }^{99}$ Tc Immobilization.” Journal of Nuclear Materials 348:272-282.

Singh D, R Ganga, J Gaviria, and Y Ysufoglu. 2011. Secondary Waste Form Testing Ceramicrete Phosphate Bonded Ceramics. ANL-11/16, Argonne National Laboratory, Argonne, Illinois. 
Sivaprasad P, K Ramesh, and YP Reddy. 1990. “Optical Absorption Spectrum of Nickel Doped $\mathrm{MgKPO}_{4} \cdot 6 \mathrm{H}_{2} \mathrm{O}$.” Solid State Communications 73(3):239-241.

Spence RD and C Shi. 2005. Stabilization and Solidification of Radioactive and Mixed Waste. CRC Press, Boca Raton, Florida.

Taylor AW, AW Frazier, and EL Gurney. 1963. "Solubility Products of Magnesium Ammonium and Magnesium Potassium Phosphates." Transactions of the Faraday Society 59:1580-1589.

THOR Treatment Technologies. 2009. Report for Treating Hanford LAW and WTP SW Simulants: Pilot Plant Mineralizing Flowsheet., RT-21-002, Rev 1, THOR Treatment Technologies, LLC, Denver, Colorado.

U.S. Department of Energy, Office of River Protection (DOE-ORP). 2010. River Protection Project System Plan. ORP-11242, Revision 5, U.S. Department of Energy, Office of River Protection, Richland, Washington.

U.S. Department of Energy, Office of River Protection (DOE-ORP). 2011. Justification of Mission Need for the Secondary Liquid Waste Treatment Project. U.S. Department of Energy, Office of River Protection, Richland, Washington.

Vinokurov SE, YM Kulyako, OM Slyuntchex, SI Rovny, and BF Myasoedov. 2009. "Low-Temperature Immobilization of Actinides and Other Components of High-Level Waste in Magnesium Potassium Phosphate Matrices." Journal of Nuclear Materials 385:189-192.

Wagh AS. 2004. Chemically Bonded Phosphate Ceramics. Elsevier, New York.

Wagh AS and SY Jeong. 2003. "Chemically Bonded Phosphate Ceramics: I, A Dissolution Model of Formation.” Journal of the American Ceramic Society 86(11):1838-1844.

Wagh AS, SY Jeong, D Singh, RV Strain, H No, and J Wescott. 1997. "Stabilization of Contaminated Soil and Wastewater with Chemically Bonded Phosphate Ceramics." ANL/ET/CP-91063, Proceedings of Waste Management 1997 Conference, March 2-7, 1997, Tucson, Arizona.

Wagh AS, SY Jeong, and D Singh. 1999a. "High Strength Phosphate Cement Using Industrial Byproduct Ashes." Proceedings of the 1st International Engineering Foundation Conference on High Strength Concrete, July 13-18, 1997, Kona, Hawaii.

Wagh AS, D, R Strain, SY Jeong, D Reed, T Krause and D Singh. 1999b. "Stabilization of Rocky Flats Pu-Contaminated Ash within Chemically Bonded Phosphate Ceramics." Journal of Nuclear Materials 265:295-307.

Wagh A, D Singh, and SY Jeong. 2001. "Chemically Bonded Phosphate Ceramics for Stabilization and Solidification of Mixed Waste." Encyclopedia of Environmental Technology, CRC Press, pp. 6.3-1 to 6.3-18. 
Wagh AS, MD Maloney, GH Thomson, and A Antink. 2003. "Investigations in Ceramicrete

Stabilization of Hanford Tank Wastes." Proceedings of Waste Management 2003 Conference, eds R Post and M Wacks, February 23-27, 2003, Tucson, Arizona.

Washington State Department of Ecology, U.S. Environmental Protection Agency and U.S. Department of Energy (Ecology, EPA, and DOE). 1989. Hanford Facility Agreement and Consent Order, As Amended. Washington State Department of Ecology, U.S. Environmental Protection Agency, and U.S. Department of Energy, Olympia, Washington. 


\section{Appendix A}

Supplemental Treatment Technology Selection Decision Goals, Criteria, Measures, Technology Issues, and Testing Objectives 
Supplemental Treatment Technology Selection Decision Goals, Criteria, and Measures ${ }^{(a)}$

\begin{tabular}{|c|c|c|c|}
\hline Goal & Criterion & Measures & Data Package Contents \\
\hline Ensure worker and public safety & Achieve inherently safe system & Independent safety expert assessment & $\begin{array}{l}\text { Process description, equipment } \\
\text { description, process temperatures, } \\
\text { hazardous chemicals, worker dose, } \\
\text { hydrogen generation, process } \\
\text { effluents, flammable gases }\end{array}$ \\
\hline \multirow{3}{*}{$\begin{array}{l}\text { Provide environmental protection } \\
\text { comparable to current vitrified waste } \\
\text { disposal plan }\end{array}$} & Waste form performance & $\begin{array}{l}\text { Flux at points of undisturbed soil and } \\
\text { bottom of the waste packages }\end{array}$ & See next table. \\
\hline & Disposal space required & Acres of land for disposal site & $\begin{array}{l}\text { Waste loading, density, package } \\
\text { design }\end{array}$ \\
\hline & Secondary wastes produced & $\begin{array}{l}\text { Potential to emit (PTE) constituents: } \\
\text { solid waste volume, liquid waste } \\
\text { volume }\end{array}$ & $\begin{array}{l}\text { Process description, flowsheet } \\
\text { description, off gas generation, and } \\
\text { secondary wastes expected }\end{array}$ \\
\hline \multirow[t]{2}{*}{ Maximize schedule acceleration } & Confidence in meeting 2028 date & $\begin{array}{l}50 \% \text { probability data for achieving } 10 \\
\text { GPM throughput }\end{array}$ & Unknown \\
\hline & Process robustness & $\begin{array}{l}\text { Metric tons of sodium }(\mathrm{Na}) \text { processed } \\
\text { by } 2028\end{array}$ & $\begin{array}{l}\text { Range of wastes compositions tested, } \\
\text { waste loading range, concentration } \\
\text { (water content), sodium molarity }\end{array}$ \\
\hline \multirow[t]{2}{*}{ Maximize cost effectiveness } & Life cycle cost & Life cycle cost & $\begin{array}{l}\text { Process description, flowsheet } \\
\text { description, off gas generation, and } \\
\text { secondary wastes expected, dry } \\
\text { materials description. Reference/cite } \\
\text { cost data if located in literature. }\end{array}$ \\
\hline & Peak year cost & Peak year cost & $\begin{array}{l}\text { Process description, flowsheet } \\
\text { description, off gas generation, and } \\
\text { secondary wastes expected, dry } \\
\text { materials description }\end{array}$ \\
\hline Maximize operability & Operability risk & $\begin{array}{l}\text { Independent expert assessment to } \\
\text { include number of unit operations, } \\
\text { equipment count, etc. }\end{array}$ & $\begin{array}{l}\text { Process description, flowsheet } \\
\text { description }\end{array}$ \\
\hline
\end{tabular}


Supplemental Treatment Technology Selection Decision Goals, Criteria, and Measures ${ }^{(a)}$

\begin{tabular}{llll}
\hline \multicolumn{1}{c}{ Goal } & \multicolumn{1}{c}{ Criterion } & \multicolumn{1}{c}{ Measures } & \multicolumn{1}{c}{ Data Package Contents } \\
\hline $\begin{array}{l}\text { Minimize overall system interface } \\
\text { impacts }\end{array}$ & System interface impacts & $\begin{array}{l}\text { Liquid effluent greater that Effluent } \\
\text { Treatment Facility (ETF) capacity }\end{array}$ & $\begin{array}{l}\text { Secondary waste is at back end. ETF } \\
\text { upgrade to provide capacity. }\end{array}$ \\
& & $\begin{array}{l}\text { Dose of waste package (impacting } \\
\text { handling within disposal system }\end{array}$ & NA \\
& $\begin{array}{l}\text { Volume returned to double-shell } \\
\text { tanks (DSTs) (impacting stored waste } \\
\text { volume) }\end{array}$ & NA \\
\hline
\end{tabular}

(a) Raymond RE, RW Powell, DW Hamilton, WA Kitchen, BM Mauss, TM Brouns. 2004. Initial Selection of Supplemental Treatment Technologies for Hanford's Low-Activity Tank Waste. RPP-19763, WM-04 Conference, February 29-March 4, 2004, Tucson, Arizona. 
Summary of Testing Recommendations for Containerized Grout Technology-Waste Form Performance ${ }^{(a)}$

\begin{tabular}{|c|c|c|c|}
\hline Technical Issue/Uncertainty & Testing Objective & Specific Testing & Data Package Content \\
\hline \multirow[t]{2}{*}{$\begin{array}{l}\text { Data on nitrate/nitrite and } \mathrm{Cr} \text { release } \\
\text { rates from test samples to meet PA } \\
\text { data needs }\end{array}$} & $\begin{array}{l}\text { Optimize grout formulation to } \\
\text { provide highest waste loading with } \\
\text { lowest release rate. Performance on } \\
\text { nitrate/nitrite likely to be limiting } \\
\text { factor on waste loading. }\end{array}$ & $\begin{array}{l}\text { Prepare grout samples and conduct } \\
\text { leach tests (ANSI/ANS 16.1) with } \\
\text { samples that have cured for a } \\
\text { maximum of } 28 \text { days. Report leach } \\
\text { rates for nitrate/nitrite and } \mathrm{Cr} \text { at } 5 \\
\text { days, but continue to collect data for } \\
\text { full } 90 \text { days. }\end{array}$ & $\begin{array}{l}\text { Leach Data including } \\
\text { ANSI/ANS16.1, EPA 1315, ASTM } \\
\text { 1308. Location of contaminants } \\
\text { within waste form phases, } \\
\text { mechanisms of containment, } \\
\text { mechanisms of release, dissolution of } \\
\text { waste form phases, diffusion } \\
\text { coefficients/LI for Cr, nitrate, nitrite. }\end{array}$ \\
\hline & $\begin{array}{l}\text { Determine waste } \\
\text { loading/performance relationship } \\
\text { (until a target for release rate is set, } \\
\text { the relationship is more important } \\
\text { than determining a waste loading that } \\
\text { meets a criterion). }\end{array}$ & $\begin{array}{l}\text { Prepare grout samples from simulants } \\
\text { with waste loadings that vary over at } \\
\text { minimum of } 3 \times(\text { e.g., } 10 \text { to } 30 \% \text { or } 1 \\
\text { to } 3 \%) \text {. Conduct leach tests as per } \\
\text { above. }\end{array}$ & $\begin{array}{l}\text { Impact of waste loading on leaching. } \\
\text { Identify constituents impacting waste } \\
\text { loading and waste form setting. }\end{array}$ \\
\hline \multirow[t]{2}{*}{$\begin{array}{l}\text { Retention of Tc, } \mathrm{U} \text {, and I as a } \\
\text { function of waste loading }\end{array}$} & $\begin{array}{l}\text { Gather enough } \mathrm{Tc}, \mathrm{U} \text {, and I release } \\
\text { rate data to meet PA data needs. }\end{array}$ & $\begin{array}{l}\text { Prepare grout samples and conduct } \\
\text { leach tests (ANSI/ANS 16.1) with } \\
\text { samples that have cured for a } \\
\text { maximum of } 28 \text { days. Report leach } \\
\text { rates for Tc, U, and I at } 5 \text { days, but } \\
\text { continue to collect data for full } 90 \\
\text { days. }\end{array}$ & $\begin{array}{l}\text { Leach Data including } \\
\text { ANSI/ANS16.1, EPA 1315, ASTM } \\
\text { 1308. Location of contaminants } \\
\text { within waste form phases, } \\
\text { mechanisms of containment, } \\
\text { mechanisms of release, dissolution of } \\
\text { waste form phases, diffusion } \\
\text { coefficients/LI for Tc, I, and Re. }\end{array}$ \\
\hline & $\begin{array}{l}\text { Determine waste } \\
\text { loading/performance relationship } \\
\text { (until a target for release rate is set, } \\
\text { the relationship is more important } \\
\text { than determining a waste loading that } \\
\text { meets a criterion.) }\end{array}$ & $\begin{array}{l}\text { Prepare grout samples from simulants } \\
\text { with waste loadings that vary over at } \\
\text { minimum of } 3 \times(\text { e.g., } 10 \text { to } 30 \% \text { or } 1 \\
\text { to } 3 \%) \text {. Conduct leach tests as per } \\
\text { above. }\end{array}$ & $\begin{array}{l}\text { Impact of waste loading on leaching. } \\
\text { Identify constituents impacting waste } \\
\text { loading and waste form setting. }\end{array}$ \\
\hline
\end{tabular}


Summary of Testing Recommendations for Containerized Grout Technology-Waste Form Performance ${ }^{(a)}$

Technical Issue/Uncertainty

Identification of constituents that might be poorly retained by grout and may impact permitting

Validity of simulant testing

Testing Objective

Determine other key risk drivers and make suitable measurements to support calculations/models. RCRA metals, other radionuclides (e.g., Cs), all listed waste constituents (series of codes for solvents F001-F005), LDR organics and inorganics, and criteria metrics-fish bioassay.

\section{Demonstrate that simulant and actual} waste release rates match.

Verify that solidification materials locally available at the Hanford Site produce desired results.

Specific Testing

Data Package Content

Take leachate solutions from the testing on waste forms generated with actual waste and analyze for all constituents shown to be in the waste at levels of concern. Both

ANSI/ANS 16.1 and TCLP leachates will be tested.

At a loading suggested by the vendor, produce three waste form samples from simulated waste and three from actual waste. Conduct leach tests (ANSI/ANS 16.1) on each simulant and actual waste set cured under identical conditions. Samples must cure for a maximum of 28 days.

Report leach rates for nitrate/nitrite, $\mathrm{Cr}, \mathrm{Tc}, \mathrm{U}$, and I at 5 days but continue to collect data for full 90 days.

At a loading suggested by the vendor, produce a fourth waste form sample from simulated waste and another from actual waste. Conduct TCLP tests on a sample from the simulant and a sample from actual waste cured under identical conditions.

Studies with formulations that use routine solidification agents, such as cement and fly ash, should use samples obtained from local sources to help verify that regional differences in solidification agents will not introduce potential consistency problems.
RCRA metals, nitrates, nitrites, chlorides, fluorides, organics, etc. in wastes and in waste form dry materials. TCLP, fish test.

\section{Do not expect to see any data on} actual secondary wastes. Look at work done with actual LAW wastes.

\begin{tabular}{lll} 
Verify that solidification materials & $\begin{array}{l}\text { Studies with formulations that use } \\
\text { locally available at the Hanford Site } \\
\text { produce desired results. }\end{array}$ & $\begin{array}{l}\text { routine solidification agents, such as } \\
\text { cement and fly ash, should use } \\
\text { samples obtained from local sources } \\
\text { materials. } \\
\text { to help verify that regional alternative sources of dry } \\
\text { differences in solidification agents } \\
\text { will not introduce potential } \\
\text { consistency problems. }\end{array}$ \\
\hline
\end{tabular}


Summary of Testing Recommendations for Containerized Grout Technology-Waste Form Performance ${ }^{(a)}$

Technical Issue/Uncertainty

Effects of mitigating features on environmental performance

\author{
Determine efficacy of proposed \\ "getters."
} features for preventing contaminants from leaving the disposal system.

Estimate expected efficacy of proposed feature for long-term Hanford application.

\section{Data to support grout facility design Collect grout curing and strength} data.

Specific Testing

Data Package Content

Prepare grout samples and conduct proposed process.

container.

Collect data on amount of leachate generated as grout cures (or use existing data with engineering analysis if sufficient to address issue). leach tests (ANSI/ANS 16.1) with samples cured for a maximum of 28 days. Report leach rates for nitrate/nitrite and target COC (e.g., Tc) at 5 days; continue to collect data for full 90 days.

Conduct accelerated disposal tests at conditions representative of the

Hanford disposal site to show mitigated release of contaminants.

Conduct accelerated disposal tests to identify operable range limits for

Perform engineering evaluation on laboratory data from accelerated disposal test demonstration.

\section{Determine the heat release per} volume of grout and thermal conductivities of the proposed grouts.

Measure grout strength as a function of curing temperature.

Measure the $\mathrm{H}_{2}$ generation for the final proposed grout formulation.

Summarize data on testing with getter reductants, $\mathrm{SnCl}_{2}$, etc. Compare with and without getters, short term data and long term performance.

Any long term test data. PCT, SPFT, PUF, EPA 1313, 1314, 1316.

Any Hanford-specific long-term data. Otherwise out of scope (disposal facility design).

\section{Estimate amount of leachate that is} released during the curing process. materials. BFS, Ag zeolite,
Heat of curing, thermal conductivity, source of heat

Impact of curing temperature on waste form performance

Not an issue for secondary waste

Identify any free liquids.

Provide any data or calculated values.

Valuable data but may not directly impact down-selection.

(a) Josephson, GB, LM Bagaasen, JGH Geeting, PA Gauglitz, GJ Lumetta, JS Tixier. 2003. Hanford Mission Acceleration Initiative - Preliminary Testing Recommendations for Supplemental Treatment. PNNL-14005 Rev.1. Pacific Northwest National Laboratory, Richland, Washington. 
Appendix B

Initial Draft Waste Form Selection/Waste Acceptance Criteria for Hanford WTP Secondary Waste Form 


\section{Appendix B}

\section{Initial Draft Waste Form Selection/Waste Acceptance Criteria for Hanford WTP Secondary Waste Form}

The attached table provides initial draft waste acceptance criteria and waste form selection criteria for secondary liquid wastes from the Hanford Tank Waste Treatment and Immobilization Plant (WTP). It is assumed that the secondary wastes will be treated and solidified in the Effluent Treatment Facility (ETF) before disposal in the Integrated Disposal Facility (IDF). The criteria were developed originally in 2004 and were based on the Hanford Site Solid Waste Acceptance Criteria as well as the waste acceptance criteria for the immobilized low-activity waste glass waste form to be prepared in WTP for disposal in IDF. In 2004 and 2005, Integrated Disposal Facility Waste Acceptance Criteria (RPP-8402) were drafted. The latest available version for this exercise is a draft Rev 1, dated February 23, 2005.

The first three columns provide the original secondary waste form requirements, including the title of the requirement, the requirement itself, and the technical basis for the requirement. The fourth column

provides the corresponding requirement from the IDF WAC. The fifth column identifies the data package content to address the requirement. 


\section{Initial Draft Waste Form Selection/Waste Acceptance Criteria for Hanford WTP Secondary Waste Form}

\begin{tabular}{|c|c|c|c|c|}
\hline Property & Requirement & Basis & Idf Waste Acceptance Criteria ${ }^{(a)}$ & Data Package Content \\
\hline $\begin{array}{l}1.2 .2 .1 \\
\text { Return Streams }\end{array}$ & $\begin{array}{l}\text { There shall be no return streams } \\
\text { from the secondary waste } \\
\text { stabilization facilities. }\end{array}$ & $\begin{array}{l}\text { The process should not generate } \\
\text { off-gas effluents. Any "bleed" } \\
\text { water from curing or set-up of the } \\
\text { stabilizing material (e.g., grout or } \\
\text { other material) can be mitigated by } \\
\text { design. }\end{array}$ & & $\begin{array}{l}\text { Process description, } \\
\text { flowsheet description }\end{array}$ \\
\hline $\begin{array}{l}1.2 .2 .2 \\
\text { Package } \\
\text { Description }\end{array}$ & $\begin{array}{l}\text { The constituent parts of each } \\
\text { package are a sealed metal container } \\
\text { enclosing the stabilized secondary } \\
\text { waste form and an optional filler } \\
\text { material. }\end{array}$ & $\begin{array}{l}\text { The disposal infrastructure planned } \\
\text { in conjunction with the Integrated } \\
\text { Disposal Facility (IDF) includes } \\
\text { systems for handling cylindrical } \\
\text { WTP canisters, solid waste drums } \\
\text { and boxes, and potentially large ( } 8 \\
\mathrm{ft} \times 8 \mathrm{ft} \times 20 \mathrm{ft} \text { ) roll-off boxes for } \\
\text { the supplemental treatment waste } \\
\text { form. The preferred option for } \\
\mathrm{SSW} \text { is to use one of the currently } \\
\text { planned disposal system packages } \\
\text { and corresponding interfaces. The } \\
\text { use of a different container may be } \\
\text { more efficient, but will have to be } \\
\text { evaluated against the disposal } \\
\text { system impacts. }\end{array}$ & $\begin{array}{l}\text { 4.3.1 Package Construction } \\
\text { Containers must be made of or lined } \\
\text { with materials that will not react } \\
\text { with, and are otherwise compatible } \\
\text { with, the dangerous waste during } \\
\text { handling and storage before disposal } \\
\text { such that the capability of the } \\
\text { container to contain the waste is not } \\
\text { impaired. } \\
\text { Waste containers are limited to } \\
\text { those constructed of noncombustible } \\
\text { or fire retardant materials. } \\
\text { Container materials will be limited } \\
\text { to the following: } \\
\text { - Metal, concrete, masonry } \\
\text { - Other not listed here }\end{array}$ & $\begin{array}{l}\text { Range of packages } \\
\text { defined in IDF WAC. } \\
\text { Provide description of } \\
\text { waste form including } \\
\text { chemical form. }\end{array}$ \\
\hline
\end{tabular}


Initial Draft Waste Form Selection/Waste Acceptance Criteria for Hanford WTP Secondary Waste Form

\begin{tabular}{|c|c|c|c|c|}
\hline Property & Requirement & Basis & Idf Waste Acceptance Criteria ${ }^{(a)}$ & Data Package Content \\
\hline $\begin{array}{l}1.2 .2 .3 \\
\text { Size and } \\
\text { Configuration }\end{array}$ & $\begin{array}{l}\text { Package size and configuration } \\
\text { should be selected considering the } \\
\text { disposal infrastructure at IDF and } \\
\text { performance requirements and } \\
\text { objectives. IDF will include } \\
\text { capability to handle WTP canisters } \\
\text { (304 stainless-steel right circular } \\
\text { cylinder, } 2.3 \mathrm{~m} \text { high, and } 1.22 \mathrm{~m} \text { in } \\
\text { diameter), standard } 55 \text { gal and } 85 \\
\text { gal drums, and may include other } \\
\text { larger containers. }\end{array}$ & See 1.2.2.2 Package Description & $\begin{array}{l}\text { 4.3.2 Size } \\
\text { Only containers meeting the type, } \\
\text { size and construction specified in } \\
\text { this section have been evaluated for } \\
\text { criticality safety. No other } \\
\text { container types are approved for } \\
\text { disposal at the IDF unless a } \\
\text { criticality safety evaluation is } \\
\text { performed. } \\
\text { Type } 2 \text { : LLW waste packaged in } \\
\text { 208L (55-gal) drums } \\
\text { Type } 3 \text { : LLW waste packaged in } \\
322 \mathrm{~L} \text { ( } 85 \text {-gal) drums } \\
\text { Type } 4: \mathrm{LWW} \text { waste packaged in } \\
\text { MB-V boxes measuring } 1.2 \mathrm{~m} \text { wide } \\
\mathrm{x} 1.2 \mathrm{~m} \text { high } \mathrm{x} 2.4 \mathrm{~m} \text { long ( } 4 \text {-ft } \mathrm{x} 4- \\
\mathrm{ft} \times \mathrm{ft} \text { ) } \\
\text { Type } 5 \text { : LLW waste packaged in } \\
\text { medium boxes greater than or equal } \\
\text { to } 3.95 \mathrm{~m}^{3} \text { but less than } 15 \mathrm{~m}^{3} \text {. The } \\
\text { dimensions are not fixed. } \\
\text { Type } 6 \text { : LLW waste packaged in } \\
\text { small boxes less than } 3.95 \mathrm{~m}^{3} \text {. The } \\
\text { dimensions are not fixed. }\end{array}$ & $\begin{array}{l}\text { Package size and } \\
\text { configuration not } \\
\text { expect to impact waste } \\
\text { form selection. }\end{array}$ \\
\hline $\begin{array}{l}1.2 .2 .4 \\
\text { Mass }\end{array}$ & $\begin{array}{l}\text { The mass of each loaded package } \\
\text { shall not exceed } 85 \text { metric tons. }\end{array}$ & $\begin{array}{l}\text { The maximum mass is calculated } \\
\text { considering the limitations (force } \\
\text { per unit surface area) of the IDF } \\
\text { liner system and transportation } \\
\text { system. The } 85 \text { metric ton limit is } \\
\text { specific to the footprint of the large } \\
\text { metal roll-off boxes, and it is } \\
\text { assumed that they were fully } \\
\text { loaded with supplemental ILAW } \\
\text { glass. }\end{array}$ & & Waste load and density \\
\hline
\end{tabular}


Initial Draft Waste Form Selection/Waste Acceptance Criteria for Hanford WTP Secondary Waste Form

\begin{tabular}{|c|c|c|c|c|}
\hline Property & Requirement & Basis & Idf Waste Acceptance Criteria ${ }^{(a)}$ & Data Package Content \\
\hline $\begin{array}{l}1.2 .2 .5 \\
\text { Closure and } \\
\text { Sealing }\end{array}$ & $\begin{array}{l}\text { A means of mitigating hydrogen } \\
\text { generation shall be provided in the } \\
\text { package closure design. A Nucfil } \\
013^{\mathrm{TM}} \text { filter (or equivalent) shall be } \\
\text { used in combination with a } \\
\text { hydrogen recombination catalyst to } \\
\text { prevent loss of radionuclides from } \\
\text { the container or hydrogen } \\
\text { accumulation in the disposal } \\
\text { configuration. Pouring a non- } \\
\text { radioactive cold cap as a filler } \\
\text { material is recommended. }\end{array}$ & $\begin{array}{l}\text { Provide equivalence to HNF-EP- } \\
0063 \text {, Rev 10, Section } 3.36 \text {, Gas } \\
\text { Generation. Some level of } \\
\text { radiolytic decomposition may } \\
\text { occur in the SSW and hydrogen } \\
\text { may evolve. }\end{array}$ & $\begin{array}{l}\text { 4.1.11 Gas Generation } \\
\text { When waste is packaged, vents or } \\
\text { other measures shall be provided if } \\
\text { the potential exists for pressurizing } \\
\text { or generating flammable or } \\
\text { explosive concentrations of gases } \\
\text { within the waste container. }\end{array}$ & $\begin{array}{l}\text { Package closure and } \\
\text { sealing not expected to } \\
\text { be a factor in waste } \\
\text { form selection. }\end{array}$ \\
\hline $\begin{array}{l}\text { 1.2.2.6 } \\
\text { Labeling }\end{array}$ & $\begin{array}{l}\text { Each package shall be labeled in } \\
\text { accordance with the requirements of } \\
\text { the Integrated Disposal Facility } \\
\text { Waste Acceptance Criteria. (RPP- } \\
8402 \text { ) }\end{array}$ & See 1.2.2.2 Package Description & $\begin{array}{l}\text { 4.3.5 Marking and Labeling } \\
\text { Containers of low-level waste shall } \\
\text { be marked such that their contents } \\
\text { can be identified. Packages shall be } \\
\text { labeled according to the instructions } \\
\text { in Appendix C. }\end{array}$ & $\begin{array}{l}\text { Package labeling not } \\
\text { expected to be a factor } \\
\text { in waste form } \\
\text { selection. }\end{array}$ \\
\hline $\begin{array}{l}1.2 .2 .7 \\
\text { Void Space }\end{array}$ & $\begin{array}{l}\text { The void space in the container shall } \\
\text { not exceed } 10 \text { percent of the total } \\
\text { internal volume at the time of filling } \\
\text { with the SSW and optional filler } \\
\text { material. }\end{array}$ & $\begin{array}{l}\text { Meets the requirements of } \\
\text { Dangerous Waste Regulation } \\
\text { WAC 173-303-665 (12); i.e., the } \\
\text { container shall be at least } 90 \\
\text { percent full when placed in the } \\
\text { landfill. }\end{array}$ & $\begin{array}{l}\text { 4.1.4 Solidification and Stabilization } \\
\text { All containerized waste must fill at } \\
\text { least } 90 \text { percent of the internal } \\
\text { volume of the container when } \\
\text { placed in the disposal unit. }\end{array}$ & $\begin{array}{l}\text { Describe process } \\
\text { demonstrations, bench, } \\
\text { engineering, pilot, and } \\
\text { full-scale. }\end{array}$ \\
\hline
\end{tabular}


Initial Draft Waste Form Selection/Waste Acceptance Criteria for Hanford WTP Secondary Waste Form

\begin{tabular}{|c|c|c|c|c|}
\hline Property & Requirement & Basis & Idf Waste Acceptance Criteria ${ }^{(a)}$ & Data Package Content \\
\hline $\begin{array}{l}1.2 .2 .8 \\
\text { Radionuclide } \\
\text { Concentration } \\
\text { Limitations }\end{array}$ & $\begin{array}{l}\text { The radionuclide concentration of } \\
\text { the SSW shall not exceed levels } \\
\text { corresponding to a waste category } 3 \\
\text { as defined in the IDF WAC. }\end{array}$ & $\begin{array}{l}\text { Meets the requirements of } \\
10 \text { CFR } 61.55 \text { and Hanford site solid } \\
\text { waste acceptance criteria. }\end{array}$ & $\begin{array}{l}\text { 1.5 Waste Types Accepted for } \\
\text { Disposal } \\
\text { The IDF will accept low-level waste } \\
\text { and mixed waste. LLW is } \\
\text { radioactive waste that is not high- } \\
\text { level radioactive waste, spent } \\
\text { nuclear fuel, transuranic waste, } \\
\text { byproduct material, or naturally } \\
\text { occurring radioactive material. } \\
\text { 4.2.1 Radiological Concentration } \\
\text { Radiological concentrations must } \\
\text { meet all of the following conditions: } \\
\text { - TRU content shall not exceed } \\
\quad 100 \text { nanocuries } \\
\quad \text { (3,700 becquerels) per gram of } \\
\quad \text { waste. } \\
\quad \text { Waste category shall not exceed } \\
\quad \text { Category } 3 \text {. } \\
4.2 .2 \text { Dose-Equivalent Curie Limits } \\
\text { The dose-equivalent curie (DE-Ci) } \\
\text { for Category } 1 \text { waste cannot exceed } \\
1 \text { DE-Ci/m }{ }^{3} \text {. The De-Ci for } \\
\text { Category } 3 \text { waste cannot exceed } 107 \\
\text { DE-Ci/m }{ }^{3} \text {. } \\
4.2 .3 \text { Fissile Material Content } \\
\text { The fissionable material limit of any } \\
\text { one container is restricted to } 10 \\
\text { fissile gram equivalents per cubic } \\
\text { foot of container volume. }\end{array}$ & Waste loading \\
\hline
\end{tabular}


Initial Draft Waste Form Selection/Waste Acceptance Criteria for Hanford WTP Secondary Waste Form

\begin{tabular}{|c|c|c|c|c|}
\hline Property & Requirement & Basis & Idf Waste Acceptance Criteria ${ }^{(a)}$ & Data Package Content \\
\hline $\begin{array}{l}1.2 .2 .9 \\
\text { Radiological } \\
\text { Composition } \\
\text { Documentation }\end{array}$ & $\begin{array}{l}\text { The radionuclide composition of the } \\
\text { waste form shall be documented. } \\
\text { Radionuclides shall be identified } \\
\text { that are significant as defined in } \\
\text { NUREG/BR-0204 and } \\
\text { 49CFR } 172.101 \text { (Table } 2 \text { ). } \\
\text { Technetium-99 ( }{ }^{99} \mathrm{Tc} \text { ) shall be } \\
\text { considered to be significant at } \\
\text { concentrations greater than } \\
0.003 \mathrm{Ci} / \mathrm{m}^{3} \text { in the SSW form. The } \\
\text { inventories shall be indexed to } \\
\text { December } 31,2002 \text {. The } \\
\text { documentation shall be consistent } \\
\text { with the radiological description } \\
\text { format described in NUREG/BR- } \\
0204 \text {. }\end{array}$ & $\begin{array}{l}\text { Equivalent to WTP approach for } \\
\text { ILAW }\end{array}$ & $\begin{array}{l}\frac{4.2 .1 \text { Radiological Concentration }}{\text { Radionuclide concentrations must }} \\
\text { be reported in accordance with } \\
\text { Appendix A. }\end{array}$ & $\begin{array}{l}\text { Project record. Not } \\
\text { part of data package. }\end{array}$ \\
\hline $\begin{array}{l}\text { 1.2.2.10 } \\
\text { Surface Dose } \\
\text { Rate Limitations }\end{array}$ & $\begin{array}{l}\text { The dose rate at any point on the } \\
\text { external surface of the package shall } \\
\text { not exceed } 2 \text { milliSieverts per hour } \\
\text { ( } 200 \text { millirem per hour) at contact } \\
\text { and } 1 \text { milliSievert per hour ( } 100 \\
\text { millirem per hour ) at } 30 \mathrm{~cm}(11.8 \\
\text { inches). }\end{array}$ & Interface with the disposal system & $\begin{array}{l}\text { 4.2.6 Dose Rate Limits } \\
\text { Containers with dose rates less than } \\
\text { or equal to } 2 \text { milliSieverts per hour } \\
\text { ( } 200 \text { millirem per hour) at contact } \\
\text { and less than } 1 \text { milliSievert per hour } \\
\text { (100 millirem per hour ) at } 30 \mathrm{~cm} \\
(11.8 \text { inches) are acceptable. }\end{array}$ & $\begin{array}{l}\text { Get WRPS hazard } \\
\text { analysis. Waste } \\
\text { loading. }\end{array}$ \\
\hline $\begin{array}{l}1.2 .2 .11 \\
\text { Surface } \\
\text { Contamination } \\
\text { Limitations }\end{array}$ & $\begin{array}{l}\text { Removable contamination on the } \\
\text { external surfaces of the package } \\
\text { shall not exceed } 367 \mathrm{~Bq} / \mathrm{m}^{2} \text { for alpha } \\
\text { and } 3670 \mathrm{~Bq} / \mathrm{m}^{2} \text { for beta-gamma } \\
\text { contamination when measured using } \\
\text { the method described in } \\
\text { 49CFR173.443(a). }\end{array}$ & Interface with the disposal system & $\begin{array}{l}\text { 4.2.4 Package Removable } \\
\text { Contamination } \\
\text { Removable contamination on } \\
\text { accessible surfaces of waste } \\
\text { packages shall not exceed the limits } \\
\text { of HNF-5183, Tank Farm } \\
\text { Radiological Control Manual. }\end{array}$ & $\begin{array}{l}\text { Process description, } \\
\text { flowsheet description }\end{array}$ \\
\hline
\end{tabular}


Initial Draft Waste Form Selection/Waste Acceptance Criteria for Hanford WTP Secondary Waste Form

\begin{tabular}{|c|c|c|c|c|}
\hline Property & Requirement & Basis & Idf Waste Acceptance Criteria ${ }^{(a)}$ & Data Package Content \\
\hline $\begin{array}{l}1.2 .2 .12 \\
\text { External } \\
\text { Temperature }\end{array}$ & $\begin{array}{l}\text { The temperature of the accessible } \\
\text { external surfaces of the package } \\
\text { shall not exceed } 50^{\circ} \mathrm{C} \text { when returned } \\
\text { to DOE. This temperature } \\
\text { constraint shall assume a shaded, } \\
\text { still air environment at an ambient } \\
\text { temperature of } 38^{\circ} \mathrm{C} \text {. }\end{array}$ & Interface with the disposal system & $\begin{array}{l}\text { 4.1.13 Heat Generation } \\
\text { Waste must not generate excess heat } \\
\text { that would compromise the integrity } \\
\text { of both contained and nearby } \\
\text { wastes. If heat generation from } \\
\text { radiological decay in the waste } \\
\text { package exceeds } 4.1 \text { watts per cubic } \\
\text { meter }(0.1 \text { watt per cubic foot), the } \\
\text { package must be evaluated to verify } \\
\text { that the heat does not affect the } \\
\text { integrity of the container or } \\
\text { surrounding containers. The } \\
\text { maximum temperature is limited by } \\
\text { the } 71.1^{\circ} \mathrm{C} \text { allowable design } \\
\text { temperature at the primary } \\
\text { geomembrane. }\end{array}$ & $\begin{array}{l}\text { Radiogenic heat is not } \\
\text { an issue. Document } \\
\text { heat of curing. Curing } \\
\text { time, set time. }\end{array}$ \\
\hline
\end{tabular}


Initial Draft Waste Form Selection/Waste Acceptance Criteria for Hanford WTP Secondary Waste Form

\begin{tabular}{|c|c|c|c|c|}
\hline Property & Requirement & Basis & Idf Waste Acceptance Criteria ${ }^{(a)}$ & Data Package Content \\
\hline $\begin{array}{l}1.2 .2 .13 \\
\text { Free Liquids }\end{array}$ & $\begin{array}{l}\text { The package shall contain no } \\
\text { detectable free liquids as defined in } \\
\text { ANSI/ANS-55.1 or SW-846 } \\
\text { Method } 9095 \text {. }\end{array}$ & Compliance with 10CFR61 & $\begin{array}{l}\text { 4.1.3 Liquids and Liquid Containing } \\
\text { Wastes } \\
\text { Liquid waste must be solidified or } \\
\text { packaged in sufficient absorbent } \\
\text { material to absorb twice the volume } \\
\text { of liquid. Liquid waste or wastes } \\
\text { containing liquids must be } \\
\text { converted into a form that contains } \\
\text { as little free-standing and non- } \\
\text { corrosive liquid as is reasonably } \\
\text { achievable, but in no case shall the } \\
\text { liquid exceed } 1 \% \text { of the volume of } \\
\text { the waste when the waste is in a } \\
\text { disposal container designed to } \\
\text { verify stability, or } 0.5 \% \text { of the } \\
\text { volume after it is processed to a } \\
\text { stable form. } \\
\text { For waste that has the potential for } \\
\text { free liquid formation, the absence or } \\
\text { presence of free liquids in the waste } \\
\text { must be demonstrated using the } \\
\text { following test method: Method } 9095 \\
\text { (Paint Filter Liquids Test) as } \\
\text { described in EPA Publication } \\
\text { SW- } 846 \text {. }\end{array}$ & $\begin{array}{l}\text { Document free liquids } \\
\text { in laboratory and scale } \\
\text { testing. Under what } \\
\text { conditions were free } \\
\text { liquids observed. }\end{array}$ \\
\hline
\end{tabular}


Initial Draft Waste Form Selection/Waste Acceptance Criteria for Hanford WTP Secondary Waste Form

\begin{tabular}{|c|c|c|c|c|}
\hline Property & Requirement & Basis & Idf Waste Acceptance Criteria ${ }^{(a)}$ & Data Package Content \\
\hline $\begin{array}{l}\text { 1.2.2.14 } \\
\text { Pyrophoricity or } \\
\text { Explosivity }\end{array}$ & $\begin{array}{l}\text { The package contents shall not be } \\
\text { pyrophoric, readily capable of } \\
\text { detonation, or readily capable of } \\
\text { explosive decomposition or reaction } \\
\text { (including reaction with water) at } \\
\text { normal pressure and temperature. } \\
\text { The waste form and any optional } \\
\text { filler materials shall not be ignitable } \\
\text { or reactive as defined in } \\
\text { WAC 173-303-090(5) and } \\
\text { WAC 173-303-090(7). }\end{array}$ & Compliance with WAC. & $\begin{array}{l}\text { 4.1.9 Explosives } \\
\text { Waste must not be readily capable } \\
\text { of detonation or of explosive } \\
\text { decomposition or reaction at } \\
\text { anticipated pressures and } \\
\text { temperatures, or of explosive } \\
\text { reaction with water. } \\
\text { 4.1.10 Pyrophoric Wastes } \\
\text { Pyrophoric materials contained in } \\
\text { the waste shall be treated, prepared, } \\
\text { and packaged to be nonflammable. }\end{array}$ & $\begin{array}{l}\text { Describe waste form } \\
\text { including chemistry } \\
\text { and starting materials. }\end{array}$ \\
\hline $\begin{array}{l}1.2 .2 .15 \\
\text { Explosive or } \\
\text { Toxic Gases }\end{array}$ & $\begin{array}{l}\text { The loaded package shall not } \\
\text { contain or be capable of generating } \\
\text { quantities of explosive (e.g., } \\
\text { hydrogen) or toxic gases, vapors, or } \\
\text { fumes harmful to persons handling } \\
\text { the waste. }\end{array}$ & $\begin{array}{l}\text { SSW may generate radiolytic } \\
\text { hydrogen that must be accounted } \\
\text { for in the design. }\end{array}$ & $\begin{array}{l}\text { 4.1.11 Gas Generation } \\
\text { Waste must not contain, or be } \\
\text { capable of generating quantities of } \\
\text { toxic gases, vapor, or fumes harmful } \\
\text { to the public, workers, or disposal } \\
\text { facility personnel, or harmful to the } \\
\text { long-term structural stability of the } \\
\text { disposal site. }\end{array}$ & $\begin{array}{l}\text { Describe waste form } \\
\text { including chemistry } \\
\text { and starting materials. } \\
\text { Radiogenic hydrogen } \\
\text { is not expected to be } \\
\text { an issue with } \\
\text { secondary wastes. } \\
\text { Decide how to address } \\
\text { ammonia in SBS } \\
\text { recycle. }\end{array}$ \\
\hline
\end{tabular}


Initial Draft Waste Form Selection/Waste Acceptance Criteria for Hanford WTP Secondary Waste Form

\begin{tabular}{|c|c|c|c|c|}
\hline Property & Requirement & Basis & Idf Waste Acceptance Criteria $^{(a)}$ & Data Package Content \\
\hline $\begin{array}{l}1.2 .2 .16 \\
\text { Dangerous } \\
\text { Waste } \\
\text { Limitations }\end{array}$ & $\begin{array}{l}\text { The loaded package shall be } \\
\text { acceptable for land disposal under } \\
\text { the State of Washington Dangerous } \\
\text { Waste Regulations, WAC 173-303, } \\
\text { and RCRA LDR in } 40 \text { CFR268. } \\
\text { The waste form shall undergo full } \\
\text { analysis of all constituents for } \\
\text { applicability to these regulations, } \\
\text { including testing using the Toxicity } \\
\text { Characteristic Leaching Procedure } \\
\text { (TCLP: SW-846, Method 1311) to } \\
\text { verify that limits for regulated } \\
\text { metals are met. }\end{array}$ & $\begin{array}{l}\text { Compliance with applicable } \\
\text { Washington State and federal } \\
\text { RCRA requirements. }\end{array}$ & $\begin{array}{l}\text { 4.1.1 Hazardous Waste } \\
\text { The IDF will accept waste with the } \\
\text { following dangerous waste } \\
\text { numbers: D001, D002, D003, D004 } \\
\text { through D043, State only (WT01, } \\
\text { WT02, WP01, WP02, WP03, } \\
\text { WSC2, and W001), and listed waste } \\
\text { from non specific sources (F001 } \\
\text { through F012, F19, F028, and F039) } \\
\text { and all "U" and "P" dangerous } \\
\text { waste numbers. } \\
\\
\text { 4.1.2 Land Disposal Restrictions } \\
\text { All waste subject to Resource } \\
\text { Conservation and Recovery Act of } \\
\text { 1976 LDR) (40 CFR 268) and/or } \\
\text { Washington State LDR (WAC 173- } \\
\text { 303-140) must be demonstrated to } \\
\text { meet all applicable treatment } \\
\text { standards and requirements. Waste } \\
\text { not meeting LDR treatment } \\
\text { standards will not be accepted. }\end{array}$ & $\begin{array}{l}\text { TCLP, pH, describe } \\
\text { waste form chemical } \\
\text { composition, } \\
\text { hazardous constituents } \\
\text { in dry materials. }\end{array}$ \\
\hline
\end{tabular}


Initial Draft Waste Form Selection/Waste Acceptance Criteria for Hanford WTP Secondary Waste Form

\begin{tabular}{|c|c|c|c|c|}
\hline Property & Requirement & Basis & Idf Waste Acceptance Criteria ${ }^{(a)}$ & Data Package Content \\
\hline $\begin{array}{l}1.2 .2 .17 \\
\text { Compressive } \\
\text { Strength }\end{array}$ & $\begin{array}{l}\text { The mean compressive strength of } \\
\text { the waste form (and any optional } \\
\text { filler material) shall be determined } \\
\text { by testing representative non- } \\
\text { radioactive samples. The } \\
\text { compressive strength shall be at } \\
\text { least } 3.45 \mathrm{E} 6 \mathrm{~Pa} \text { when tested in } \\
\text { accordance with ASTM C } 39 / \mathrm{C} 39 \mathrm{M}- \\
99 \text { or an equivalent testing method. }\end{array}$ & $\begin{array}{l}\text { NRC Branch Position Paper. } \\
\text { Technical Position on Waste Form. }\end{array}$ & $\begin{array}{l}\text { 4.1.4 Solidification and Stabilization } \\
\text { A solid waste must have a minimum } \\
\text { compressive strength of } 586 \mathrm{kPa}(85 \\
\text { psi). } \\
\text { 4.2.1 Radiological Concentration } \\
\text { Category } 3 \text { waste can be disposed of } \\
\text { only if the waste meets one of the } \\
\text { following conditions of waste form } \\
\text { stability } \\
\text { - Stabilization in concrete or } \\
\text { other stabilization agents. The } \\
\text { stabilized waste must meet the } \\
\text { leach index and compression } \\
\text { strength criteria of the U.S } \\
\text { Nuclear Regulatory } \\
\text { Commission (NRC) Technical } \\
\text { Position on Waste Form, } \\
\text { Section C. } 2 \text { and Appendix A } \\
\text { (NRC 1991). }\end{array}$ & $\begin{array}{l}\text { Compressive strength } \\
\text { data, including } \\
\text { radiation effects, water } \\
\text { immersion, thermal } \\
\text { cycling, } \\
\text { biodegradation. }\end{array}$ \\
\hline $\begin{array}{l}\text { 1.2.2.18 } \\
\text { Compression } \\
\text { Testing }\end{array}$ & $\begin{array}{l}\text { Each fully loaded package shall be } \\
\text { able to withstand a compression } \\
\text { load of } 50,000 \mathrm{~kg} \text {. Compliance with } \\
\text { this specification shall be } \\
\text { established by using the } \\
\text { compression test described in } \\
49 \text { CFR } 173.465(\mathrm{~d}) \text {. The integrity of } \\
\text { the package shall be demonstrated } \\
\text { by showing that the dimensions of } \\
\text { the tested packages are within the } \\
\text { tolerance range and by showing that } \\
\text { the seal remains intact in accordance } \\
\text { with Specification for Closure and } \\
\text { Sealing }\end{array}$ & Stacking in disposal trench. & & $\begin{array}{l}\text { Waste package design. } \\
\text { Not a factor in waste } \\
\text { form selection. }\end{array}$ \\
\hline
\end{tabular}


Initial Draft Waste Form Selection/Waste Acceptance Criteria for Hanford WTP Secondary Waste Form

\begin{tabular}{|c|c|c|c|c|}
\hline Property & Requirement & Basis & Idf Waste Acceptance Criteria ${ }^{(a)}$ & Data Package Content \\
\hline $\begin{array}{l}\text { 1.2.2.19 } \\
\text { Manifesting }\end{array}$ & $\begin{array}{l}\text { A shipping manifest shall be } \\
\text { prepared for delivery with each } \\
\text { shipment of SSW product. } \\
\text { Information on the manifest shall } \\
\text { satisfy the requirements in DOE } \\
\text { Manual 435.1-1, Chapter N, Section } \\
\text { I.(2), and NUREG/BR-0204. Any } \\
\text { package containing dangerous waste } \\
\text { must be labeled and manifested in } \\
\text { accordance with WAC 173-303-370 } \\
\text { and the Dangerous Waste Portion of } \\
\text { the Resource Conservation and } \\
\text { Recovery Act Permit for } \\
\text { the Treatment, Storage, and } \\
\text { Disposal of Dangerous Wastes } \\
\text { (Permit No. WA 7890008967). }\end{array}$ & $\begin{array}{l}\text { Equivalent to WTP glass } \\
\text { packaging requirements }\end{array}$ & $\begin{array}{l}\text { 2.5 Waste Receipt and Acceptance } \\
\text { Each waste shipment must be } \\
\text { accompanied by the following } \\
\text { paperwork: } \\
\text { - A receipt report } \\
\text { - A Uniform Hazardous Waste } \\
\text { Manifest } \\
\text { - A Land Disposal Restriction } \\
\text { Notification/Certification Form } \\
\text { (waste subject to } 40 \text { CFR 268). }\end{array}$ & $\begin{array}{l}\text { Not a factor in waste } \\
\text { form selection. }\end{array}$ \\
\hline
\end{tabular}


Initial Draft Waste Form Selection/Waste Acceptance Criteria for Hanford WTP Secondary Waste Form

\begin{tabular}{|c|c|c|c|c|}
\hline Property & Requirement & Basis & Idf Waste Acceptance Criteria $^{(a)}$ & Data Package Content \\
\hline $\begin{array}{l}\text { 1.2.2.20 } \\
\text { Waste Form } \\
\text { Testing - } \\
\text { Leachability } \\
\text { Index }\end{array}$ & $\begin{array}{l}\text { The waste form shall have a sodium } \\
\text { LI greater than } 6.0 \text { when tested for } \\
90 \text { days in deionized water using the } \\
\text { ANSI/ANS- } 16.1 \text { procedure. In } \\
\text { addition, LI performance targets } \\
\text { have been established for key } \\
\text { radionuclides of concern-iodine } \\
\text { and technetium. An iodine-129 LI } \\
\text { greater than } 11.0 \text { and a technetium- } \\
99 \text { LI greater than } 9.0 \text { are desired. }\end{array}$ & $\begin{array}{l}\text { 10CFR61 and NRC Waste Form } \\
\text { Technical Position. Performance } \\
\text { targets were established based on } \\
\text { preliminary risk and PA estimates } \\
\text { of groundwater impacts from } \\
\text { immobilized LAW and SSW in an } \\
\text { Integrated Disposal Facility. The } \\
\text { goal is to achieve long-term release } \\
\text { performance from SSW that meets } \\
\text { or exceeds regulatory requirements } \\
\text { based on site-specific risk } \\
\text { assessment calculations. Note: the } \\
\text { ANSI/ANS } 16.1 \text { procedure and } \\
\text { corresponding leachability indices } \\
\text { are based on the assumption of a } \\
\text { diffusion-limited release } \\
\text { mechanism, which may not apply } \\
\text { to radionuclides of concern in the } \\
\text { specific waste form selected. } \\
\text { However, the diffusion-based LI } \\
\text { performance targets provide a } \\
\text { standard test and reference point } \\
\text { for comparison and evaluation. } \\
\text { These leachability indices } \\
\text { correspond to fractional releases of } \\
\text { iodine-129 and technetium- } 99 \text { of } \\
\text { approximately } 1 \times 10^{-05} \mathrm{Ci} / \mathrm{yr} / \mathrm{Ci} \\
\text { disposed and } 2 \times 10^{-04} \mathrm{Ci} / \mathrm{yr} / \mathrm{Ci} \\
\text { disposed, respectively. }\end{array}$ & $\begin{array}{l}\text { 4.2.1 Radiological Concentration } \\
\text { Category } 3 \text { waste can be disposed of } \\
\text { only if the waste meets one of the } \\
\text { following conditions of waste form } \\
\text { stability. } \\
\text { Stabilization in concrete or other } \\
\text { stabilization agents. The stabilized } \\
\text { waste must meet the leach index and } \\
\text { compression strength criteria of the } \\
\text { U.S Nuclear Regulatory } \\
\text { Commission (NRC) Technical } \\
\text { Position on Waste Form, Section } \\
\text { C.2 and Appendix A (NRC 1991). }\end{array}$ & $\begin{array}{l}\text { ANSI/ANS } 16.1 \text { data. } \\
\text { Include DIW data and } \\
\text { data on other } \\
\text { leachants. }\end{array}$ \\
\hline $\begin{array}{l}\text { 1.2.2.21 } \\
\text { Minimize Waste } \\
\text { Volume }\end{array}$ & $\begin{array}{l}\text { The total SSW volume shall be } \\
\text { minimized within the constraints of } \\
\text { the other specification requirements }\end{array}$ & $\begin{array}{l}\text { Disposal costs are minimized as } \\
\text { the SSW volume and package } \\
\text { count is minimized. }\end{array}$ & & $\begin{array}{l}\text { Waste loading and } \\
\text { density. }\end{array}$ \\
\hline
\end{tabular}


Initial Draft Waste Form Selection/Waste Acceptance Criteria for Hanford WTP Secondary Waste Form

\begin{tabular}{|c|c|c|c|c|}
\hline Property & Requirement & Basis & Idf Waste Acceptance Criteria ${ }^{(a)}$ & Data Package Content \\
\hline $\begin{array}{l}\text { 1.2.2.22 } \\
\text { Thermal, } \\
\text { Radiation, } \\
\text { Biodegradation } \\
\text { and Immersion } \\
\text { Stability }\end{array}$ & $\begin{array}{l}\text { The ILAW product shall be resistant } \\
\text { to thermal, radiation, biodegradation, } \\
\text { and immersion degradation, as } \\
\text { described in NRC Technical Position } \\
\text { on Waste Form. Resistance to each } \\
\text { of these types of degradation shall } \\
\text { be established by showing that the } \\
\text { mean compressive strength of } \\
\text { representative non-radioactive } \\
\text { samples shall be equal to or greater } \\
\text { than } 3.45 \mathrm{E} 06 \text { Pa and not less than } \\
75 \text { percent of the initial compressive } \\
\text { strength after subjecting the samples } \\
\text { to the following: } \\
\text { Thermal Degradation: Thirty } \\
\text { thermal cycles between a high } \\
\text { of } 60^{\circ} \mathrm{C} \text { and a low of -40 }{ }^{\circ} \mathrm{C} \text { in } \\
\text { accordance with the ASTM B553-79 } \\
\text { or an equivalent testing method. } \\
\text { Radiation Degradation: Exposure to } \\
\text { a minimum radiation dose of } 1.0 \mathrm{E} 08 \\
\text { rad or to a dose equivalent to the } \\
\text { maximum level of exposure } \\
\text { expected from self-irradiation } \\
\text { during storage, transportation and } \\
\text { disposal if this is greater than } \\
1.0 \mathrm{E} 08 \text { rad. } \\
\text { Biodegradation: No evidence of } \\
\text { culture growth when representative } \\
\text { samples are tested in accordance } \\
\text { with ASTM G21-96 and ASTM } \\
\text { G22-76 (R1996), or equivalent } \\
\text { methods. } \\
\text { Immersion degradation: Immersion } \\
\text { for } 90 \text { days under the ANSI/ANS- } \\
16.1 \text { testing conditions. }\end{array}$ & $\begin{array}{l}\text { Compliance with 10CFR61 and } \\
\text { NRC Waste Form Technical } \\
\text { Position. }\end{array}$ & $\begin{array}{l}\text { 4.2.1 Radiological Concentration } \\
\text { Category } 3 \text { waste can be disposed of } \\
\text { only if the waste meets one of the } \\
\text { following conditions of waste form } \\
\text { stability. } \\
\text { Stabilization in concrete or other } \\
\text { stabilization agents. The stabilized } \\
\text { waste must meet the LI and } \\
\text { compression strength criteria of the } \\
\text { U.S Nuclear Regulatory } \\
\text { Commission (NRC) Technical } \\
\text { Position on Waste Form, Section } \\
\text { C.2 and Appendix A (NRC 1991). }\end{array}$ & $\begin{array}{l}\text { Compressive strength } \\
\text { data including } \\
\text { radiation effects, water } \\
\text { immersion, thermal } \\
\text { cycling, } \\
\text { biodegradation. }\end{array}$ \\
\hline
\end{tabular}


Initial Draft Waste Form Selection/Waste Acceptance Criteria for Hanford WTP Secondary Waste Form

\begin{tabular}{|c|c|c|c|c|}
\hline Property & Requirement & Basis & Idf Waste Acceptance Criteria ${ }^{(a)}$ & Data Package Content \\
\hline $\begin{array}{l}1.2 .3 \\
\text { Package } \\
\text { Handling }\end{array}$ & $\begin{array}{l}\text { The package shall be compatible } \\
\text { with crane lifting and movement. } \\
\text { The package shall be equipped with } \\
\text { lifting and other handling } \\
\text { appurtenances designed to allow } \\
\text { safe lifting, movement, and stacking } \\
\text { of the packages when fully loaded. } \\
\text { The package shall maintain its } \\
\text { integrity during handling, } \\
\text { transportation, and stacking. The } \\
\text { package design shall allow for } \\
\text { vertical stacking to a total height of } \\
10 \text { meters. }\end{array}$ & $\begin{array}{l}\text { Interface with current disposal } \\
\text { system }\end{array}$ & $\begin{array}{l}\text { 4.3.4 Handling } \\
\text { All packages must be configured for } \\
\text { safe unloading by forklift or crane. } \\
\text { Packages that must be unloaded by } \\
\text { crane shall be equipped with lifting } \\
\text { and other appurtenances designed to } \\
\text { allow safe lifting, movement, and } \\
\text { stacking of the packages when fully } \\
\text { loaded. The package shall maintain } \\
\text { its integrity during handling, } \\
\text { transportation, and the lifting } \\
\text { required for disposal in IDF. }\end{array}$ & $\begin{array}{l}\text { Package design. Not } \\
\text { expected to impact } \\
\text { waste form selection. }\end{array}$ \\
\hline
\end{tabular}




\section{Distribution}

No. of

Copies

OFFSITE

1 D Singh

Argonne National Laboratory

9700 South Case Avenue

Argonne, IL 60439
No. of

Copies

ONSITE

4 Washington River Protection Solutions

MA Melvin

E6-30

DJ Swanberg

B1-55

KE Smith

E6-30

LE Thompson

11 Pacific Northwest National Laboratory

PR Bredt

KJ Cantrell

K9-09

CW Chung

K6-81

GB Josephson

K6-24

MJ Lindberg

K9-69

SV Mattigod

P7-54

LM Peurrung

K3-62

N Qafoku

K9-09

RJ Serne

P7-54

W Um

K6-81

JH Westsik, Jr

P7-54

K7-15

Distr.1 



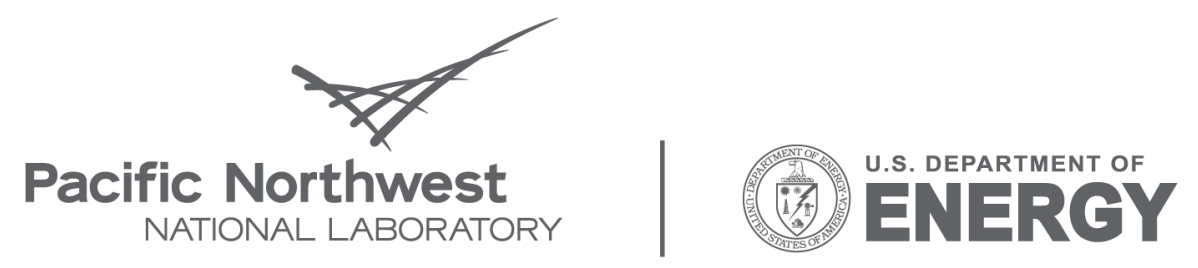

Proudly Operated by Battelle Since 1965

902 Battelle Boulevard

P.O. Box 999

Richland, WA 99352

1-888-375-PNNL (7665)

www.pnl.gov 